\title{
Recent trends in whole cell and isolated enzymes in enantioselective synthesis
}

\author{
Sinéad E. Milner ${ }^{a}$ and Anita R. Maguire $*^{b}$ \\ ${ }^{a}$ Department of Chemistry, and ${ }^{b}$ Department of Chemistry and School of Pharmacy, \\ Analytical and Biological Chemistry Research Facility, University College Cork, Cork, Ireland \\ E-mail: a.maguire@ucc.ie
}

\begin{abstract}
Modern synthetic organic chemistry has experienced an enormous growth in biocatalytic methodologies; enzymatic transformations and whole cell bioconversions have become generally accepted synthetic tools for asymmetric synthesis. This review details an overview of the latest achievements in biocatalytic methodologies for the synthesis of enantiopure compounds with a particular focus on chemoenzymatic synthesis in non-aqueous media, immobilisation technology and dynamic kinetic resolution. Furthermore, recent advances in ketoreductase technology and their applications are also presented.
\end{abstract}

Keywords: Biocatalysis, kinetic and dynamic kinetic resolution, Baker's yeast, ketoreductases

\section{Table of Contents}

1. General Introduction

2. Biocatalysis

2.1 Introduction

2.2. Enzyme classes

2.3. Advantages and disadvantages of biocatalysis

3. Biocatalysis in Non-Aqueous Media

3.1. Organic solvents

3.2. Supercritical fluids

3.3. Ionic liquids

3.4. Novel application of fluorous solvents in product isolation following biocatalysis

4. Enzyme Immobilisation

4.1. Introduction

4.2. Cross-linked enzyme aggregates

4.3. Practical applications of enzyme cross-linked enzyme aggregates

5. Genetic Engineering of Enzymes 
5.1. Rational design and directed evolution

5.2. Practical applications of genetically modified enzymes

6. Kinetic and Dynamic Kinetic Resolution - a Biological Perspective

6.1. Kinetic resolution

6.2. Dynamic kinetic resolution

6.2.1 Dynamic kinetic resolution without metal catalysis

6.2.2 Dynamic kinetic resolution with metal catalysis

7. Baker's Yeast Mediated Resolution of Sulfur Containing Compounds

7.1. Introduction

7.2. Baker's yeast reduction of sulfur containing compounds

7.3. Genetically engineered Baker's yeast

8. Ketoreductases

8.1. Introduction

8.2. Cofactor recycling systems

8.3. Examples of ketoreductase-mediated enantioenriched alcohol synthesis

9. References

\section{General Introduction}

Asymmetric synthesis is the preferential formation of one stereoisomer of a chiral target compound to another; when scientists at GlaxoSmithKline, AstraZeneca and Pfizer ${ }^{1}$ examined 128 syntheses from their companies, they found as many as half of the drug compounds made by their process research and development groups are not only chiral but also contain an average of two chiral centres each. ${ }^{2}$ In 2006 just $25 \%$ were derived from the chiral pool and over $50 \%$ employed chiral technologies. ${ }^{1}$ In order to meet regulatory requirements enantiomeric purities of $99.5 \%$ were deemed necessary by the FDA. ${ }^{3}$ This is one of the biggest challenges which face chemists today, primarily due to the recognition of the fact that different enantiomers of the same compound can interact differently in biological systems. As a consequence, the production of single enantiomers instead of racemic mixtures has become an important process in the pharmaceutical and agrochemical industry. Several routes can lead to the desired enantiomer including transition metal${ }^{4-6}$ organo- $^{5,7-10}$ and bio-catalysis ${ }^{11-15}$ and these have been thoroughly reviewed in the literature. ${ }^{16,17}$

\section{Biocatalysis}

\subsection{Introduction}

Biocatalysis involves the use of enzymes or whole cells (containing the desired enzyme or enzyme system) as catalysts for chemical reactions. A timeline of historic events in biocatalysis and biotechnology is outlined in Table $1 .{ }^{18-20}$ 
Table 1. Historical perspective of biocatalysis and biotechnology (adapted from ref. 11)

\begin{tabular}{|c|c|c|c|}
\hline Years & Who? & Where? & What? \\
\hline B.C. & Unknown & Old World & $\begin{array}{l}\text { Chymosin from calf and sheep stomach } \\
\text { employed in the production of cheese }\end{array}$ \\
\hline $\begin{array}{c}1783- \\
1836\end{array}$ & Spallanzani & $-^{a}$ & $\begin{array}{l}\text { verifies in vitro "digestion" of meat in } \\
\text { stomach juice: factor called "pepsin" }\end{array}$ \\
\hline 1876 & Kühne & $-^{a}$ & $\begin{array}{c}\text { term "enzyme" for catalysts not bound to } \\
\text { living cells }\end{array}$ \\
\hline 1877 & Eduard Buchner & $\begin{array}{l}\text { Berlin Agricultural } \\
\text { College, Germany }\end{array}$ & $\begin{array}{l}\text { First alcoholic respiration with cell-free } \\
\text { extract: vital force, vis vitalis, does not } \\
\text { exist (Nobel prize 1907) }\end{array}$ \\
\hline 1893 & Wilhelm Ostwald & $\begin{array}{l}\text { Leipzig Univ., } \\
\text { Germany }\end{array}$ & $\begin{array}{c}\text { definition of term "catalyst" } \\
\text { (Nobel prize 1909) }\end{array}$ \\
\hline 1894 & Emil Fischer & Berlin Univ.,Germany & "lock and key" analogy (Nobel prize 1902) \\
\hline 1903 & Henry D. Dakin & London, UK & $\begin{array}{c}\text { First enantioselective synthesis, } \\
\text { with oxynitrilase }\end{array}$ \\
\hline 1908 & Otto Röhm & Darmstadt,Germany & $\begin{array}{l}\text { Patent for enzymatic treatment of leather } \\
\text { (with trypsin) }\end{array}$ \\
\hline $\begin{array}{l}1913- \\
1915\end{array}$ & Röhm Company & Darmstadt,Germany & $\begin{array}{l}\text { First laundry detergent with enzyme } \\
\text { (pancreatin): "Burnus" }\end{array}$ \\
\hline 1926 & James B. Sumner & $\begin{array}{l}\text { Cornell Univ., Ithaca, } \\
\text { NY, USA }\end{array}$ & $\begin{array}{c}\text { First enzyme crystallised: urease from jack } \\
\text { beans (Nobel prize 1946) }\end{array}$ \\
\hline 1936 & Ernst Sym & & Lipase reaction in organic solvent \\
\hline 1944 & Linus Pauling & $\begin{array}{l}\text { Caltech, Pasadena, CA, } \\
\text { USA }\end{array}$ & $\begin{array}{l}\text { First attempt to explain enzyme catalysis } \\
\text { as transition-state complementarity }\end{array}$ \\
\hline 1950 & Pehr Edman & Univ. of Lund, Sweden & Protein degradation developed \\
\hline 1951 & $\begin{array}{l}\text { Frederick Sanger } \\
\text { and Hans Tuppy }\end{array}$ & $\begin{array}{l}\text { Univ. Of Cambridge, } \\
\text { UK }\end{array}$ & $\begin{array}{l}\text { Sequence determination of insulin } \beta \text {-chain: } \\
\text { each protein is characterised by a sequence } \\
\text { (Nobel prize 1978) }\end{array}$ \\
\hline 1960 & $-{ }^{\mathrm{a}}$ & $\begin{array}{l}\text { Novo (Bagsvaerd, } \\
\text { Denmark) }\end{array}$ & $\begin{array}{c}\text { Large-scale protease production from } \\
\text { Bacillus licheniformis in submerged } \\
\text { culture }\end{array}$ \\
\hline 1963 & $\begin{array}{l}\text { Stanford Moore } \\
\text { and William Stein }\end{array}$ & $\begin{array}{l}\text { Rockfeller Univ., NY, } \\
\text { USA }\end{array}$ & $\begin{array}{l}\text { Amino acid sequence of lysozyme and } \\
\text { ribonuclease elucidated (Nobel prize 1972) }\end{array}$ \\
\hline 1978 & $\begin{array}{l}\text { Stanley Cohen and } \\
\text { Herbert Boyer }\end{array}$ & Stanford, CA, USA & $\begin{array}{c}\text { Method of recombination of DNA } \\
\text { developed }\end{array}$ \\
\hline 1985 & Michael Smith & $\begin{array}{l}\text { Univ. of British } \\
\text { Columbia, Canada }\end{array}$ & $\begin{array}{l}\text { Site-directed gene mutagenesis to change } \\
\text { enzyme sequence (Nobel prize 1993) }\end{array}$ \\
\hline
\end{tabular}


Table 1. Continued

\begin{tabular}{cccc}
\hline Years & Who? & Where? & What? \\
\hline \multirow{2}{*}{1988} & Kary B. Mullis & Cetus Corp., CA, & Invention of PCR (Nobel prize and Japan Prize \\
& & USA & 1993) \\
2000 & Celera Genomics & $\begin{array}{c}\text { Gaithersburg, MD, } \\
\text { USA }\end{array}$ & $\begin{array}{c}\text { Sequencing of human genome announced (3 } \\
\text { billion basepairs) }\end{array}$ \\
\hline
\end{tabular}

${ }^{a}$ Not described.

\section{Established Chemistries}

Resolution (lipase/protease)

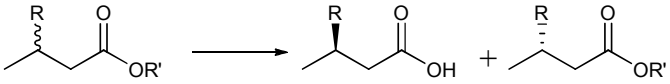

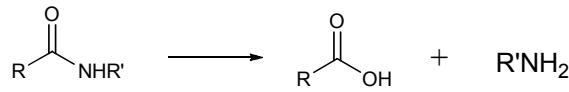

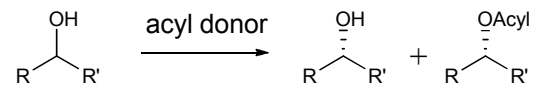

$$
\begin{aligned}
& \overbrace{\mathrm{R}^{\prime}}^{\mathrm{NH}_{2}} \stackrel{\text { acyl donor }}{\longrightarrow} \overbrace{\mathrm{R}^{\prime}}^{\mathrm{NH}_{2}}+\overbrace{\mathrm{C}^{\prime}}^{\stackrel{N}{\mathrm{NHAcyl}^{\prime}}}
\end{aligned}
$$

Hydrolysis (lipase/protease)

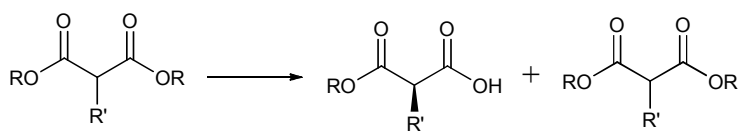

Ketone reduction

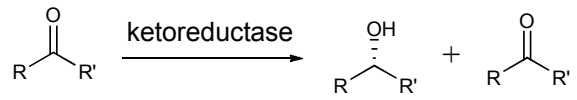

\section{Expanding Chemistries}

Nitrile reduction<smiles>[R]C([R])C([R])C(=O)O</smiles>

Cyanohydrin synthesis

$$
{\stackrel{\mathrm{O}}{\mathrm{R}^{\prime}}}_{\text {oxynitralase }}^{\mathrm{HCN}} \stackrel{\mathrm{HO}}{\mathrm{X}_{\mathrm{R}^{\prime}}^{\mathrm{CN}}}
$$

\section{Emerging Chemistries}

Transamination

$$
\stackrel{\mathrm{O}}{\stackrel{\text { transaminase }}{\longrightarrow}} \stackrel{\mathrm{CO}}{\mathrm{NH}}_{\mathrm{CO}_{2} \mathrm{H}}^{\mathrm{NH}_{2}}
$$

\section{Enoate reduction}

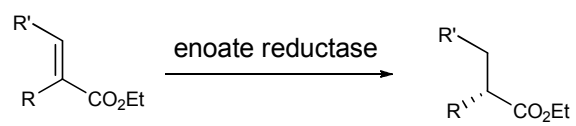

Hydroxylation

$$
\overbrace{R^{\prime}} \stackrel{\text { Cytochrome P450 }}{\longrightarrow} \overbrace{R^{\prime}}^{O H}
$$

Dihydroxylation

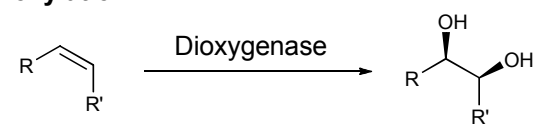

\section{Baeyer-Villiger oxidation}

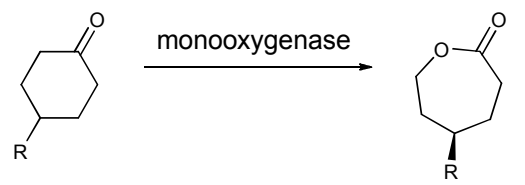

Hydrolysis

$$
\mathrm{R}_{\mathrm{R}^{\prime}}^{\text {epoxide hydrolase }} \overbrace{\mathrm{i}_{\mathrm{O} H}^{\mathrm{H}}}^{\mathrm{R}^{\prime}}
$$

\section{Epoxidation}

$$
\overbrace{\mathrm{R}^{\prime}} \stackrel{\text { monooxygenase }}{\longrightarrow} \overbrace{\mathrm{R}^{\prime}}^{\stackrel{\mathrm{O}}{\mathrm{O}}}
$$

Halohydrin formation

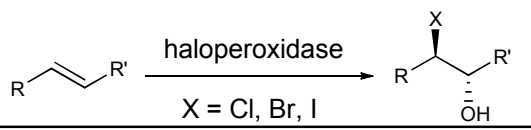

Figure 1. Adapted from ref. 25. 
Novel methodologies for discovering industrial enzymes based on genomic sequencing and phage display (discussed further in Section 1.3), ${ }^{21,22}$ as well as highly effective optimisation tools based on chemical, physical and molecular biology approaches, ${ }^{23}$ have improved the access to biocatalysts, increased their stability, and radically broadened their specificity. ${ }^{24}$ This greater availability of catalysts with superior qualities including the use of new bioengineering tools contributed significantly to the development of new industrial processes. Biocatalytic methodologies for organic synthesis were outlined by Woodley et al. in three categories: established, emerging and expanding chemistries as depicted in Figure $1 .^{25}$

\subsection{Enzyme classes}

By the late 1950s it had become evident that the nomenclature of enzymes without any guiding authority, in a period when the number of known enzymes was increasing rapidly, led to a lack of clarity. The naming of enzymes by individual workers had proved inefficient; the same enzymes became known by several different names, while conversely the same name was sometimes given to different enzymes. Many of the names conveyed no information of the nature of the reactions catalysed, and similar names were sometimes given to enzymes of different types. The International Commission on Enzymes was established in 1956 by the President of the International Union of Biochemistry in order to resolve the issue of nomenclature. ${ }^{26}$ The EC classification system is derived from the biochemical function of enzymes in living systems. Every enzyme is given four numbers after the abbreviation EC. The first number describes the reaction type (only six are possible), the second number defines the structural changes which occur during the enzyme catalysis; the third number outlines particular enzyme characteristics involved in the catalytic reaction and the fourth number is a running number. This classification now contains over 3000 entries (Table 2). ${ }^{13,19,27}$

Table 2. Summary of enzyme classes (adapted from ref. 13)

\begin{tabular}{|c|c|c|}
\hline Enzyme & Examples & Reaction catalysed \\
\hline Hydrolases & $\begin{array}{l}\text { Lipase, protease, esterase, nitrilase, nitrile } \\
\text { hydratase, glycosidase, phosphatase }\end{array}$ & Hydrolysis reaction in water \\
\hline Oxidoreductases & $\begin{array}{c}\text { Dehydrogenase, oxidase, oxygenase, } \\
\text { peroxidase }\end{array}$ & Oxidation or reduction \\
\hline Transferases & $\begin{array}{c}\text { Transaminase, glycosyltransferase, } \\
\text { transaldolase }\end{array}$ & $\begin{array}{c}\text { Transfer of a group from one } \\
\text { molecule to another }\end{array}$ \\
\hline Lyases & $\begin{array}{c}\text { Decarboxylase, dehydratase, deoxyribose- } \\
\text { phosphate aldolase }\end{array}$ & Non-hydrolytic bond cleavage \\
\hline Isomerases & Racemase, mutase & Intramolecular rearrangement \\
\hline Ligases & DNA ligase & $\begin{array}{l}\text { Bond formation requiring } \\
\text { triphosphate }\end{array}$ \\
\hline
\end{tabular}




\subsection{Advantages and disadvantages of biocatalysis}

Enzyme catalysed reactions up to the last decade had many associated advantages and disadvantages which are outlined in Table 3. ${ }^{12-14,20,28-32}$ Enzymatic transformations commonly proceed with high chemo-, regio-, and enantio-selectivity and routinely achieve enantioselectivities of $>99 \%$ e.e. ${ }^{12,33-37}$ Furthermore, the introduction of the Pollution Prevention Act of $1990^{38}$ has led to an increased focus on green chemistry. Biocatalysis is compliant with the 12 principles of green chemistry; ${ }^{38,39}$ the reactions are inherently benign as they are run at low or moderate temperatures. Apart from high selectivity, the major advantage is that enzyme-catalysed reactions usually display characteristically high turnover numbers, with rate accelerations approaching or exceeding $10^{8}$.

Table 3. Characteristics of biocatalysis

\begin{tabular}{l|l}
\hline \multicolumn{1}{c|}{ Advantages } & \multicolumn{1}{c}{ Disadvantages } \\
\hline High substrate, regio- and stereo-selectivity & Limited substrate specificity \\
Benign reaction conditions & Limited enzyme availability \\
Non-toxic & Poor catalyst stability \\
Recycling is sometimes possible & Require co-substrates and/or cofactors \\
Biodegradable waste & Inactivation may occur: \\
Large rate enhancements & $-\quad$ at high temperatures \\
& $-\quad \begin{array}{l}\text { at extremes of pH } \\
\end{array}$ \\
& $-\bullet \quad$ in organic solvents \\
&
\end{tabular}

Considering that catalysis is normally carried out at ambient temperatures and pressures, the catalytic power of enzymes is remarkable. An example of the catalytic potential and the low cost application of biocatalysis is the commercial production of L-aspartic acid, an important intermediate of the commercially important artificial sweetener Aspartame ${ }^{\circledR}$. Thus, $1 \mathrm{~kg}$ of immobilised aspartate ammonia lyase produces more than $100,000 \mathrm{~kg}$ of product $\mathbf{1}$ (Scheme 1). ${ }^{40,41}$

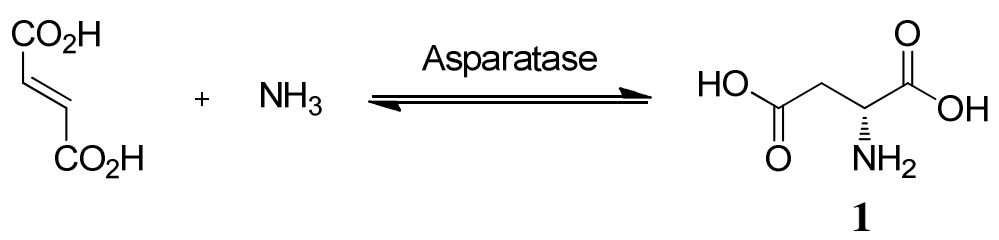

\section{Scheme 1}

The principal disadvantages associated with biocatalysis, from a synthetic perspective, are that enzymes are sensitive, unstable compounds which can be destroyed by extreme reaction conditions and tend to have a limited substrate scope in many instances. They generally function well only at physiological $\mathrm{pH}$ values in very dilute solutions of the substrate. Enzymes are expensive and 
difficult to obtain in pure form. Enzymes have also been reported to possess limited substrate scope. However, in the last 20 years the majority of these disadvantages have been overcome.

\section{Biocatalysis in Non-Aqueous Media}

A major advantage of biocatalysis is the use of water as a reaction medium owing to the low costs and waste associated with these environmentally friendly processes. Water is non-toxic, nonflammable, odourless and colourless, widely available and inexpensive and is well suited for biphasic catalysis. However, in some instances use of water as solvent is also a chief limitation of biocatalysis as many of the biocatalytic substrates are poorly water soluble and product extraction may prove difficult e.g. dehydration reactions such as esterifications do not proceed in an aqueous medium. Side reactions such as hydrolysis, polymerisation or racemisation can occur leading to product mixtures. In some instances these challenges can be circumvented through use of alternative solvents, organic solvents, supercritical fluids and ionic liquids.

\subsection{Organic solvents}

In principle, most of the problems associated with enzymes in an aqueous environment might be overcome by switching from an aqueous medium to an organic solvent. Replacement of an aqueous medium with an organic medium would seem challenging in the light of the conventional view that enzymes (and other proteins) are denatured (lose their native structure and thus catalytic activity) in organic solvents ${ }^{42}$ this assumption is derived from the examination of enzymes in aqueous-organic mixtures, not in neat organic solvent and has now been proven incorrect. ${ }^{43,44}$

Table 4. Benefits of biocatalysis in non-aqueous media

increased substrate solubility ${ }^{50}$

the kinetics of the reaction can be improved i.e. in extractive bioconversions the product can be extracted into the organic phase thereby shifting the equilibrium in favour of product formation $^{51}$

high yields are often associated with the introduction of organic solvents as their use can eradicate product inhibition and prevent the possibility of unwanted side reactions and improve the relative ease of product and biocatalyst recovery ${ }^{52}$

the regio- and chemo-selectivity of enzymes can be controlled by solvent. Conversely, the use of enzymes in non-aqueous media can lead to protein precipitation, denaturation, a reduction in catalytic activity, ${ }^{53}$ stability ${ }^{54,55}$ and a change or loss of substrate specificity

Although in aqueous-organic mixtures, protein molecules have both a propensity to denature and sufficient conformational flexibility to do so, in anhydrous solvents, due to their structural rigidity, denaturation is less likely. ${ }^{44}$ As a result, various crystalline enzymes essentially retain their native structures even in anhydrous organic solvents. ${ }^{45}$ Furthermore, protein stability is lower in 
water-miscible solvents $(-2.5<\log \mathrm{P}<0)$, such as acetone, due to their ability to remove enzyme bound water, ${ }^{46-48}$ than in hydrophobic solvents $(2<\log \mathrm{P}<4)$, such as alkanes, as they leave the water layer bound to the enzyme intact. ${ }^{49}$ The introduction of an organic solvent has several benefits as described in Table 4.

Studies over the past 15 years have established firmly that many enzymes can work in organic solvents containing little or no water and the employment of organic solvents as a reaction medium has been reviewed in detail. ${ }^{52,56,57}$ Biocatalytic solvent systems commonly include monophasic aqueous-organic mixtures, biphasic aqueous-organic mixtures and enzymes suspended in pure organic solvents. In a biphasic system (Figure $2 \mathrm{a}$ ), the enzyme is in a hydrophilic state present in the aqueous phase while the hydrophobic compounds are typically in the organic phase. In reverse micellar systems, the enzymes are solubilised in surfactants to form a hydrated reverse micelle (Figure 2b) in an organic solvent. In organic solvent systems (Figure 2c), the enzyme, either lyophilised or on an inert solid support, is suspended in an organic solvent system; aqueous buffer $(<5 \%)$ may also be present to maintain enzyme activity.

a) Biphasic system

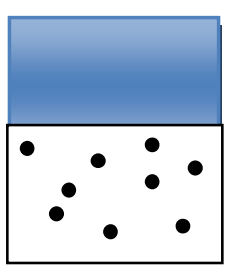

b) Reverse micellar system

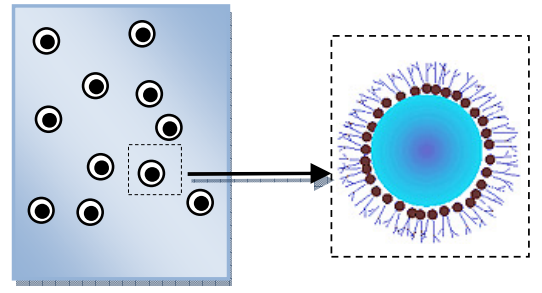

c) Organic solvent system

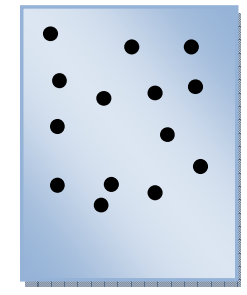

\section{Figure 2}

Several industrial syntheses now employ enzyme-catalysed reactions in organic media for the large-scale production of active pharmaceutical ingredients. For instance, Schering-Plough synthesise an azole antifungal agent $\mathbf{2}$ in hundred-kilogram quantities whereby the pivotal synthetic step is an enzymatic desymmetrisation of a symmetrical diol $\mathbf{3}$ by Novozym $435^{\circledR}$ with vinyl acetate as acyl donor and acetonitrile as solvent to give the monoester $\mathbf{4}$ in high enantiopurity. Acetonitrile was chosen as solvent as the subsequent iodocyclisation to $\mathbf{5}$ is carried out in acetonitrile and by simple filtration of the enzyme beads the reaction sequence was telescoped into a single step (Scheme 2). ${ }^{58}$ Bristol-Myers Squibb pharmaceutical research group have published a number of plant scale chemoenzymatic syntheses performed in organic media; some examples are depicted in Scheme $2 .^{59,60}$ 


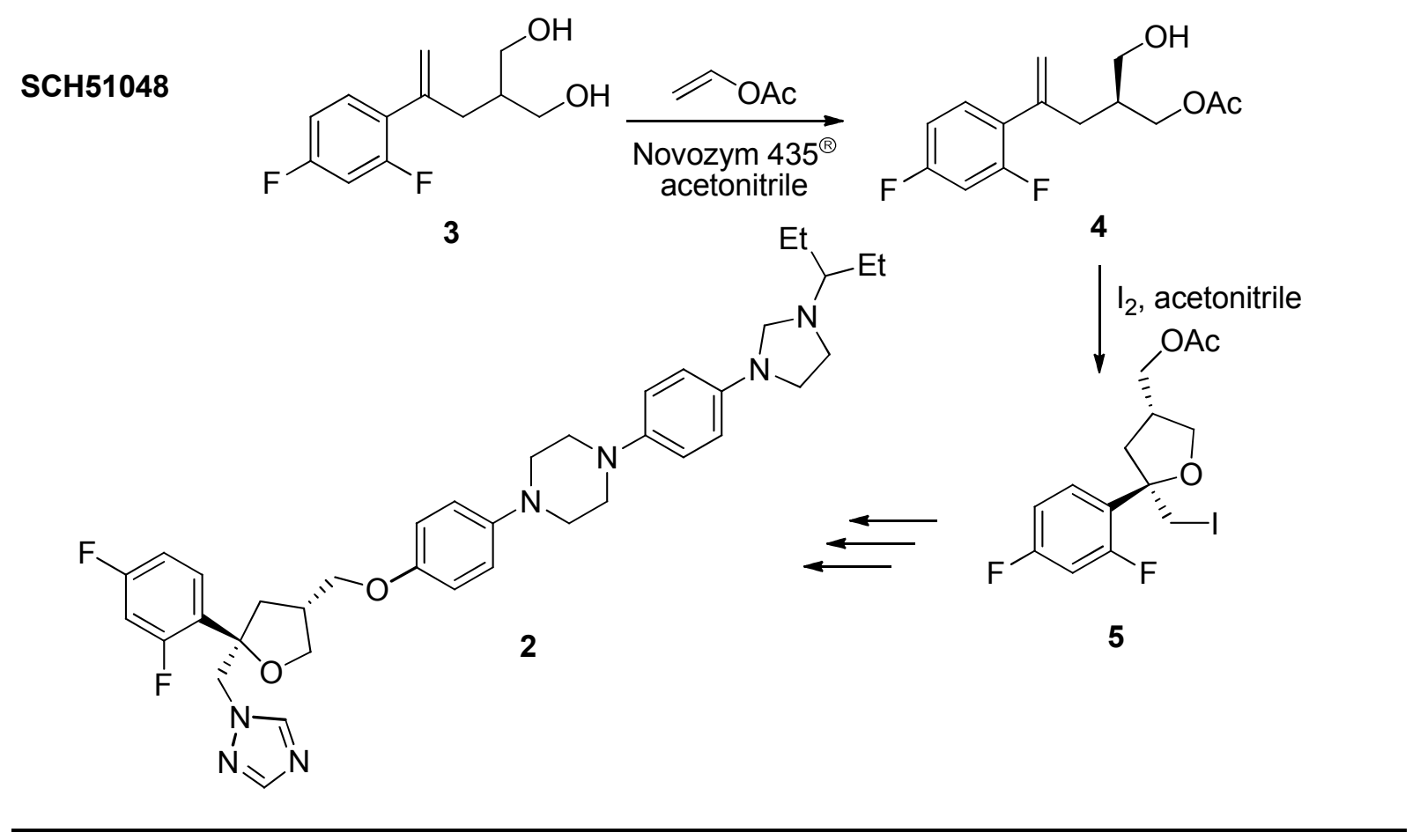

\section{Examples from Brystol-Myers Squibb}
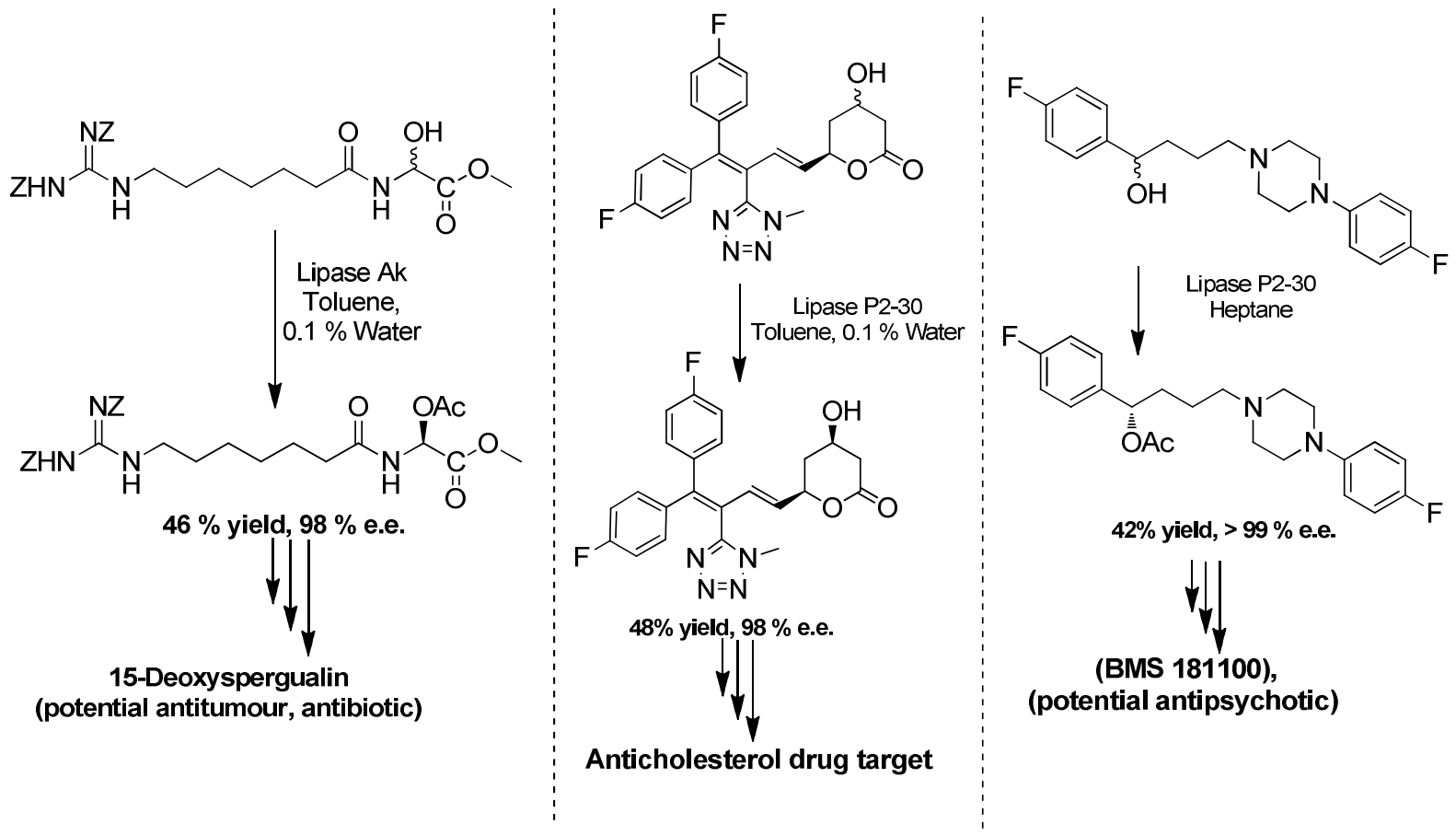

\section{Scheme 2}

A further example which demonstrates the advantages of biotransformation in organic media is the synthesis of enantiopure 2-chloro- and 2-bromo-propionic acids, used as intermediates for the 
synthesis of phenoxy propionic herbicides and some pharmaceuticals. ${ }^{61}$ These valuable chiral building blocks have been obtained from lipase catalysed enantioselective butanolysis in anhydrous solvents. Not only is this process, scaled up by Chemie Linz AG of Austria to a multikilogram level, thermodynamically impractical in water, but water also hinders the resolution by promoting racemisation. ${ }^{62}$ Although the practical utility of enzymatic catalysis in organic solvents is beyond doubt, most of the work so far has involved relatively simple, hydrolytic enzymes. ${ }^{45,63}$ Use of more complex enzymes, including those that require cofactors and especially oxidoreductases and lyases in organic solvents, is reported using organic solvent as a co-solvent, ${ }^{64-66}$ but, rarely in a neat organic solvent system. ${ }^{67-71}$

\subsection{Supercritical fluids}

In recent years enzyme catalysed processes have been explored in novel media such as supercritical fluids and ionic liquids. A supercritical fluid (SCF) is defined as the physical state of a compound or element above its critical temperature and critical pressure but below the pressure required to condense it to a solid. $^{72,73}$

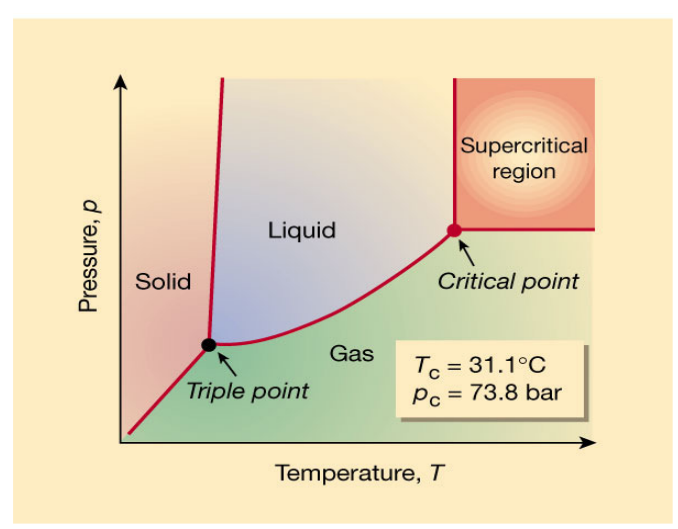

Figure 3. Reproduced from ref. 73.

The phase diagram for supercritical fluids in Figure 3 describes the phase behaviour of substances; the critical point is the point at which the densities of the liquid and gas become identical and fluid is said to be supercritical. The critical parameters of the primary solvents employed in biocatalysis are outlined in Table $5 .{ }^{11}$ Due to the temperature-sensitive nature of biocatalysts, a narrow range of supercritical fluids are investigated. The vast majority of research has employed the use of supercritical carbon dioxide $\left(\mathrm{scCO}_{2}\right)$, as it is inexpensive, benign, readily available, and has low toxicity and its relatively low supercritical parameters facilitate its use as a solvent for biocatalysis. ${ }^{74-76}$ Other supercritical fluids including freons $\left(\mathrm{CHF}_{3}\right){ }^{77}$ hydrocarbons (ethane, ethene and propane $)^{78}$ or inorganic compounds $\left(\mathrm{SF}_{6}, \mathrm{~N}_{2} \mathrm{O}\right)^{79}$ have also been reported as media for biocatalysis. 
Table 5. Critical parameters of solvents employed in biocatalysis (adapted from ref. 11)

\begin{tabular}{llll}
\hline Fluid & $\mathrm{T}_{\mathrm{c}}\left({ }^{\circ} \mathrm{C}\right)$ & $\mathrm{P}_{\mathrm{c}}(\mathrm{bar})$ & $\delta_{\mathrm{c}}(\mathrm{g} / \mathrm{mL})$ \\
\hline Ethylene & 9.5 & 50.8 & 0.22 \\
$\mathrm{CHF}_{3}$ & 25.9 & 46.9 & 0.52 \\
$\mathrm{CO}_{2}$ & 31.3 & 73.8 & 0.47 \\
Ethene & 32.3 & 48.8 & 0.20 \\
$\mathrm{SF}_{6}$ & 45.5 & 37.1 & 0.74 \\
Propane & 96.6 & 42.5 & 0.22 \\
Butane & 152.0 & 37.5 & 0.27 \\
\hline
\end{tabular}

The field of investigations of enzyme catalysis in $\mathrm{scCO}_{2}$ has been continuously growing since the mid-1980s, when Randolph et al. were the first to conduct an enzymatic reaction in $\mathrm{scCO}_{2}$ using alkaline phosphatase (Scheme 3). ${ }^{80}$
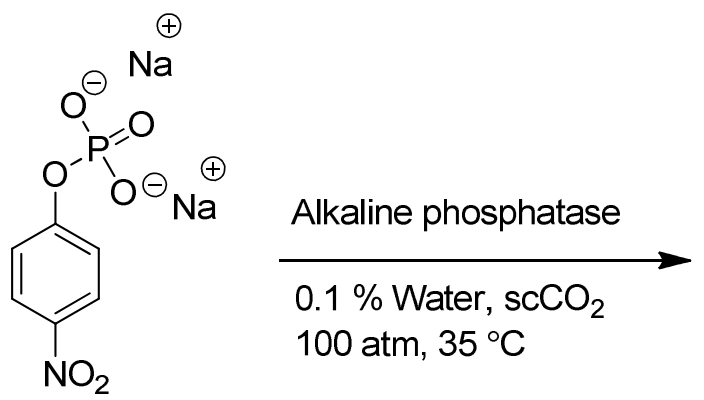<smiles>O=[N+]([O-])c1ccc(O)cc1</smiles>

$71 \%$

\section{Scheme 3}

Several reviews on enzymatic catalysis in supercritical fluids are available. ${ }^{72,78,81-84}$ The chief advantage of SCFs is the tunability of the properties of the solvent, through slight changes of the pressure and/or temperature. It is well established that success of biocatalysis (i.e. enzyme activity, specificity and enantioselectivity) in conventional solvents, is susceptible to solvent properties including dielectric constant, partition coefficient and hydrophobicity. ${ }^{85-91}$ Therefore, it is not an unexpected result that changes in the properties of SCFs dramatically affect enzyme activity.

A number of hydrolase-mediated resolutions have been performed in $\mathrm{scCO}_{2}$, in a number of cases the enantioselectivity could be controlled by variation of reaction parameters. ${ }^{63,64,92}$ For example when the enantioselectivity of lipase-catalysed esterification of 1-( $p$-chlorophenyl)-2,2,2trifluoroethanol 6 was examined in $\mathrm{scCO}_{2}$ the $E$-value of 7 changed continuously from $E=10$ to $>60$ by altering the temperature and pressure. The enantioselectivity of the reaction was higher at low pressure and low temperature (Figure 4). ${ }^{93}$ 
<smiles>OC(c1ccc(Cl)cc1)C(F)(F)F</smiles>

$( \pm)-6$

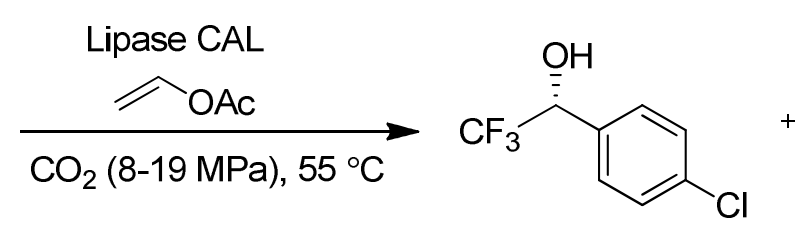

$(R)-6$<smiles>CC(=O)O[C@@H](c1ccc(Cl)cc1)C(F)(F)F</smiles>

(S)-7

\begin{tabular}{ccc}
\hline $\begin{array}{c}\text { Temperature } \\
\left({ }^{\circ} \mathrm{C}\right)\end{array}$ & $\begin{array}{c}\text { Pressure } \\
(\mathrm{mPa})\end{array}$ & E-value \\
\hline 31 & 17 & 38 \\
31 & 8 & 60 \\
40 & 13 & 24 \\
40 & 8 & 65 \\
60 & 21 & 10 \\
60 & 9 & 40 \\
\hline
\end{tabular}

Figure 4. Effect of pressure on enantioselectivity of acetylation of $( \pm)-6$ in supercritical carbon dioxide catalyzed by lipase Novozym at $31^{\circ} \mathrm{C}, 40{ }^{\circ} \mathrm{C}$ and $60{ }^{\circ} \mathrm{C} .{ }^{94}$

Palocci et al. have described how $\mathrm{scCO}_{2}$ can modulate regioselectivity in the acylation of 6-Otrityl- $\beta$-D-glucopyranoside $\mathbf{8}$ by using lipase from Candida rugosa. The regioselectivity of the reaction was shifted towards the synthesis of 3-O-acetyl-6- $O$-trityl- $\beta$-D-glucopyranoside 9, with variation of the physicochemical parameters of $\mathrm{scCO}_{2}$, formation of a single regioisomer (9) could be effected in $91 \%$ yield (Scheme 4$).^{95}$<smiles>COC1OC2COC(O)C(O)C(O)C1O2</smiles>

8<smiles>C=COC(C)=O</smiles>

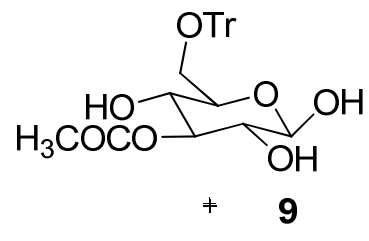

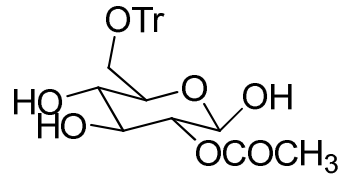

\section{Scheme 4}

In $\mathrm{scCO}_{2}$, improved enantioselectivity of transesterification reactions has been attributed to the covalent modification of enzymes by reaction with $\mathrm{CO}_{2} \cdot{ }^{96}$ High pressures (>400 MPa) can lead to irreversible structural changes in the enzyme, but within a pressure range of 10-40 MPa only reversible changes can occur. ${ }^{96}$ A high temperature is always destructive especially over long periods of time. ${ }^{96}$ Another critical parameter to enzyme activity in supercritical fluids is water 
content. The presence of some water is required as enzymes require a specific amount of water bound to them to maintain activity. A very low water content is required for enzyme activity in SCF-mediated reaction systems e.g. Novozym $(<0.05 \% \quad \mathrm{v} / \mathrm{v}),{ }^{97,98}$ lipase IM-20 (5\% v/v). ${ }^{99}$ Reductions in reaction rate were found with increasing hydrophobicity of solvents. ${ }^{82}$

The principal drawback to the use of SCFs is the requirement of specialised equipment that can withstand high pressures which has an associated increase in cost on plant scale. Adverse effects on enzymes have also been documented, $\mathrm{scCO}_{2}$ has been reported to form carbamates (Scheme 5) between $\mathrm{CO}_{2}$ and the amine groups on lysine residues, or potentially the imidazole side chain of histidine on the enzyme surface, which can lead to enzyme deactivation. ${ }^{100-102}$ In contrast, some reports detail enhanced stereoselectivity which has been attributed to carbamate formation. ${ }^{103} \mathrm{~A}$ further complication associated with the use of $\mathrm{scCO}_{2}$ is the formation of carbonic acid (Scheme 5), which results in a lowering of the $\mathrm{pH}$ of water in the microenvironment of the enzyme which can result in a change in enzyme activity. ${ }^{104}$

\section{Carbamate formation}

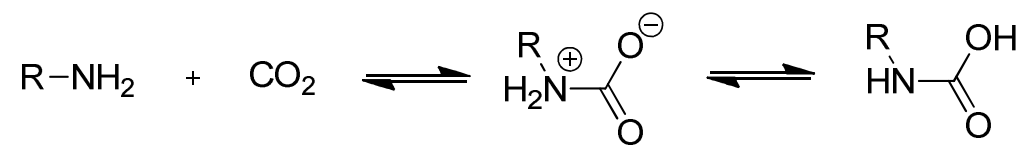

Carbonic acid formation

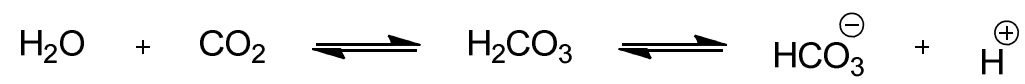

\section{Scheme 5}

Another major drawback of $\mathrm{scCO}_{2}$ is the fact that it exhibits very low solubilities for polar and ionic substances. In order to overcome this limitation, the use of microemulsions with special $\mathrm{CO}_{2}$-philic surfactants has attracted attention. Microemulsions in $\mathrm{scCO}_{2}$ allow one to dissolve hydrophilic substances such as proteins within the aqueous core of the microemulsion nanodroplets. $^{80,105}$ Moreover, they can be applied for the preparation of nanoparticles of defined size. Recently, enzymatic reactions in microemulsions in $\mathrm{scCO}_{2}$ have been reported in literature. ${ }^{106-}$ 108

\subsection{Ionic liquids}

The employment of ionic liquids (ILs) for biocatalytic reactions has received a lot of attention in the literature in the last decade and has been recently reviewed in great detail. ${ }^{109-118}$ Ionic liquids are organic salts which are liquids at room temperature. Ionic liquids possess unique properties; they are not volatile or flammable and possess excellent chemical and thermal stability, ${ }^{119}$ furthermore, they have been described as environmentally benign ${ }^{120}$ which make them an attractive alternative to traditional organic solvents. Ionic liquids possess many attractive properties, these include negligible vapour pressure, ${ }^{116}$ high polarity due to multiple ionic interactions with organic and 
inorganic compounds ${ }^{121}$ and most importantly the properties of ionic liquids such as the viscosity, hydrophobicity, density and solubility are tunable by simply varying the combination of cations and anions (Table 6).

Table 6. Typical structures of ionic liquids commonly used for biocatalysts

\begin{tabular}{|c|c|c|c|}
\hline Cations & & Anions & \\
\hline $\begin{array}{l}\text { Tetraalkylphosphonium } \\
\text { R }^{1}\end{array}$ & Anion & Full Name & Abbreviation \\
\hline & $\mathrm{BF}_{4}^{-}$ & Tetrafluoroborate & {$\left[\mathrm{BF}_{4}\right]$} \\
\hline & $\mathrm{PF}_{6}^{-}$ & Hexafluorophosphate & {$\left[\mathrm{PF}_{6}\right]$} \\
\hline $\begin{array}{l}\text { Tetraalkylammonium } \\
\qquad R^{1}\end{array}$ & $\mathrm{NO}_{3}^{-}$ & Nitrate & {$\left[\mathrm{NO}_{3}\right]$} \\
\hline & $\mathrm{CH}_{3} \mathrm{CO}_{2}^{-}$ & Acetate & {$[\mathrm{Ac}]$} \\
\hline 1, 3-Dialkylimidazolium (Im) & $\mathrm{CF}_{3} \mathrm{CO}_{2}^{-}$ & Trifluoroacetate & [Tfa] \\
\hline & $\mathrm{CH}_{3} \mathrm{OSO}_{3}^{-}$ & Methyl sulfate & {$\left[\mathrm{MeSO}_{4}\right]$} \\
\hline$-\mathrm{R}^{2}$ & $\mathrm{CF}_{3} \mathrm{SO}_{3}^{-}$ & $\begin{array}{l}\text { Trifluoromethane- } \\
\text { sulfonate }\end{array}$ & [TfO] \\
\hline 1, 3-Dialkylpyridinium (Py) & $\left(\mathrm{CF}_{3} \mathrm{SO}_{2}\right)_{2} \mathrm{~N}^{-}$ & $\begin{array}{l}\text { Bis(trifluoromethyl)- } \\
\text { sulfonimide }\end{array}$ & {$\left[\mathrm{Tf}_{2} \mathrm{~N}\right]$} \\
\hline
\end{tabular}

The first report on the employment of ionic liquids as solvent in the production of Z-aspartame by thermolysin as catalyst was in 2000 by Russell et al. (Scheme 6). ${ }^{122}$ Since this initial publication a wide range of enzymatic transformations have been investigated in ionic liquids e.g. lipases, ${ }^{123-132}$ proteases, ${ }^{133-135}$ oxidoreductases, ${ }^{136-138}$ cytochrome $\mathrm{p} 450,{ }^{139}$ peroxidase,${ }^{140-146}$ hydroxynitrile lyase ${ }^{147}$ and alcohol dehydrogenases. ${ }^{118,148}$ Ionic liquids have been reported to improve activity, ${ }^{149-153}$ selectivity $^{149,150,154-156}$ and the stability of enzymes. ${ }^{116,149,157,158}$

Biocatalytic redox reactions are often performed using whole cell biocatalysts, as the cells contain the recycling redox cofactors, and, are less susceptible to denaturation than isolated enzymes. It has been demonstrated that use of organic solvents can be replaced by an ionic liquid which seems to be less harmful to the cell membranes. ${ }^{159}$ For instance, a range of ketones were reduced enantioselectively to the corresponding $(S)$-alcohols by an immobilised yeast in $[\mathrm{BmIm}]\left[\mathrm{PF}_{6}\right]$-water $(90: 10)$ biphasic medium. On average the performance was on a par with that in an organic medium (Scheme 7). ${ }^{160}$ With isolated enzymes excellent enantioselectivity was achieved in all cases (Scheme 7). ${ }^{161}$ 


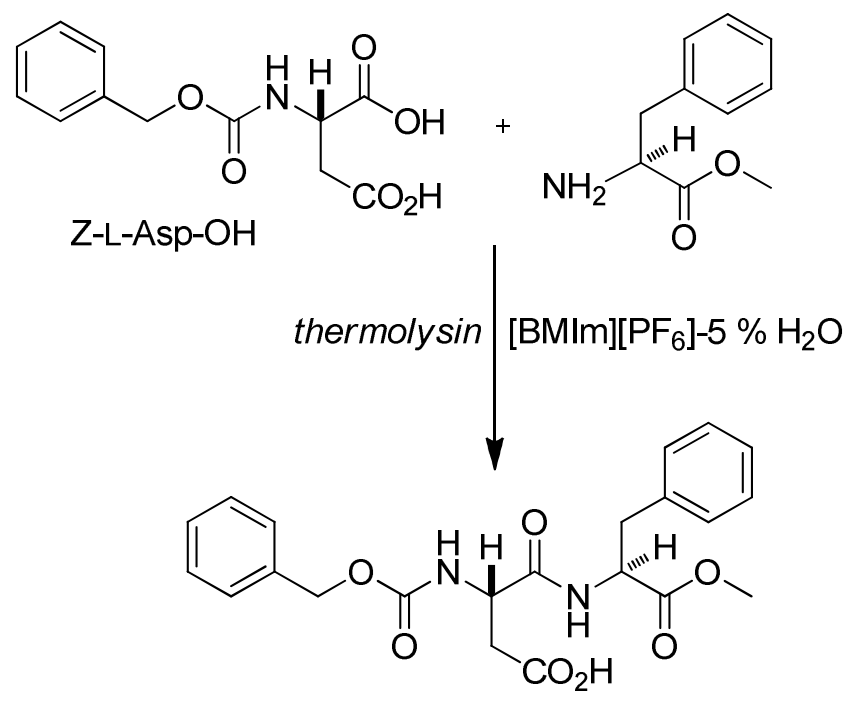

\section{Scheme 6}<smiles>[R]C([R])=O</smiles>

Whole-cell Biocatalysis<smiles>CCCC[C@@H](C)O</smiles><smiles>CC(=O)C[C@H](C)O</smiles><smiles>CCOC(=O)CC(C)O</smiles><smiles>CCOC(=O)[C@H]1CCC[C@H]1O</smiles><smiles>CCOC(=O)CC(C)O</smiles>

95 74 79 95

84 76 82 97 99 91

Isolated Enzyme Biocatalysis

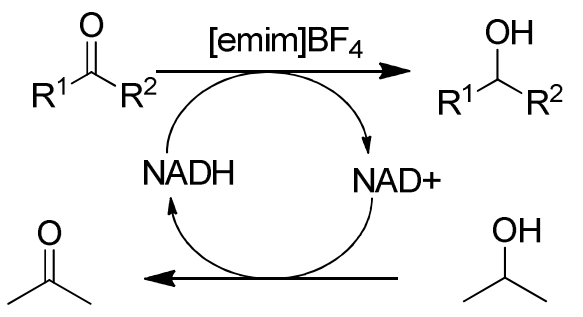<smiles>C[C@H](O)c1cc#[R]cc1</smiles>

$>99 \%$ e.e. achieved in all cases

$$
\mathrm{R}=\mathrm{H}, \mathbf{2}-\mathrm{OCH}_{3} \text {, }
$$$$
\text { 2-F, 3-F, 4-Cl }
$$<smiles>CC(O)CCc1ccccc1</smiles>

\section{Scheme 7}


Drawbacks of ionic liquids are that they are relatively expensive, and have been associated with difficult product separations. Critically, many ILs are as, or more, toxic than the organic solvents they are replacing. They have been reported to possess antibacterial activity, cytoxicity and toxicity towards multicellular organisms, ${ }^{162}$ and ecotoxicity in the case of aquatic organisms and terrestrial plants. ${ }^{163,164}$

\subsection{Novel application of fluorous solvents in product isolation following biocatalysis}

An interesting application of solvents for biocatalysis was developed in 2002 by Theil et al. ${ }^{165-167}$ Initially lipase-mediated kinetic resolution of a range of alcohols with fluorous esters was performed and repeated washing with the fluorous solvent removed the transformed ester in high enantiopurity with the untransformed alcohol remaining in the organic phase also in excellent enantiopurity. ${ }^{165}$ This methodology was adapted to lipase-mediated hydrolysis of highly fluorinated esters with similar results. ${ }^{166,167}$

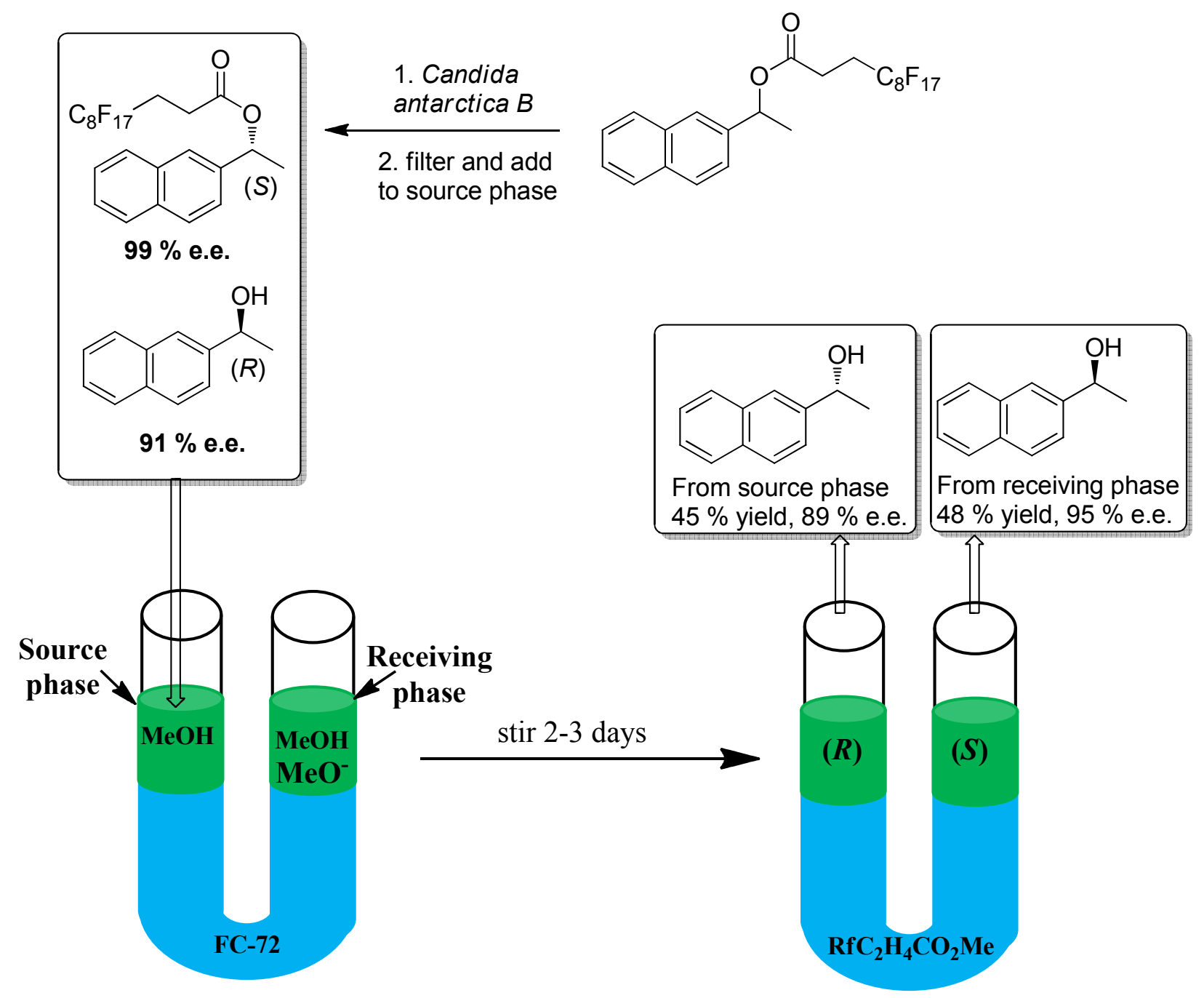

Figure 5. Adapted from ref. 167. 
Combination of the kinetic resolution by enzymatic deacylation with fluorous triphasic reaction and subsequent separation yielded the enantiomeric alcohols in excellent enantiopurities and good yields (Figure 5). The racemic ester is initially enzymatically resolved with Candida antarctica B and the mixture filtered and added to the source phase which consists of a methanol/chloroform mixture, FC-72 consists of perfluorohexanes which acts as the separation medium. The untransformed alcohol remains in the source phase while the fluorinated ester diffuses to the receiving phase which subsequently hydrolyses to the desired opposite enantiomer. The cleaved fluorous moiety mainly remains in the fluorous phase. ${ }^{167}$ This innovative example illustrates the potential for exploring differential solubility as a product isolation technique.

\section{Enzyme Immobilisation}

\subsection{Introduction}

Immobilisation typically involves attachment or dispersion of an enzyme or cell to an insoluble support material to create a heterogeneous system. The principal types of immobilisation are outlined in Figure $6 .^{168}$

a)

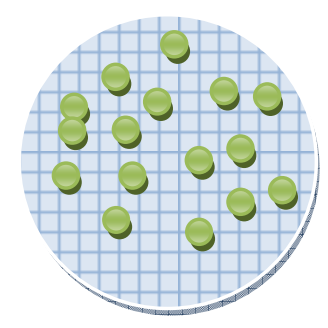

b)

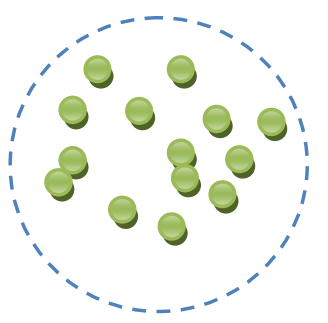

c)

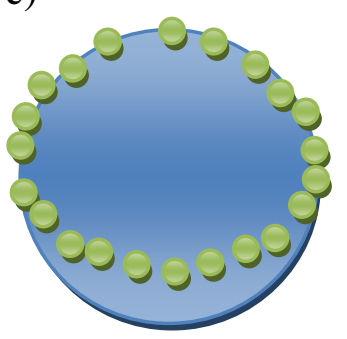

d)

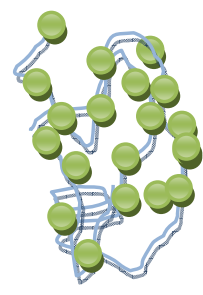

Figure 6. Enzyme immobilisation strategies: (a) entrapment, (b) encapsulation, (c) solid support, (d) enzyme crosslinking (adapted from ref. 168).

The employment of enzyme immobilisation technology has gained momentum in the last decades for several reasons. The principal advantages of immobilisation are that it allows facile recycling and repeated reuse of the biocatalyst in batch operations which significantly improves the commercial viability of enzyme-mediated processes. Immobilisation also facilitates the recovery and reuse of costly enzymes, facile handling of the enzyme and easier product recovery. Other advantages associated with enzyme immobilisation are improved enzyme performance, and increased $\mathrm{pH}$ and temperature stability. ${ }^{168-170}$ Biocatalysis in organic media is associated with the formation of enzyme aggregates, which can lead to poor accessibility of the substrate. Enzyme immobilisation has been reported to significantly increase (several hundred fold) enzyme activity in organic solvents. ${ }^{49,170,171}$ Furthermore, enhanced activity of immobilised lipases has been reported, this hyperactivity has been attributed to the lipase being trapped in its open more active conformation during the immobilisation process. ${ }^{170,172-175}$ Furthermore, modification of enzyme 
substrate selectivity has been reported by direct immobilisation through attachment of a support to a specific site on the enzyme which can lead to changes in enzyme structure and thus function. ${ }^{176}$ Comparison of the various immobilisation methods has received a lot of attention and they have been reviewed in detail. ${ }^{168-170}$

\subsection{Cross-linked enzyme aggregates}

In recent years, carrier-bound cross-linked enzyme aggregates (CLEAs) have attracted increasing attention, due to their simplicity, broad applicability, high stability, and high volume activity. Studies in the early 1960s led to the discovery that cross-linking of dissolved enzymes via reaction of surface amino groups with a chemical cross-linker such as glutardialdehyde resulted in the formation of insoluble cross-linked enzymes. ${ }^{177}$ Carrier-free immobilised enzymes are generally prepared by cross-linking enzyme preparations such as crystalline, spray-dried, dissolved or physically aggregated enzymes, resulting in the formation of cross-linked enzymes. The different approaches to carrier-free immobilised enzymes are illustrated in Figure 7. ${ }^{169}$

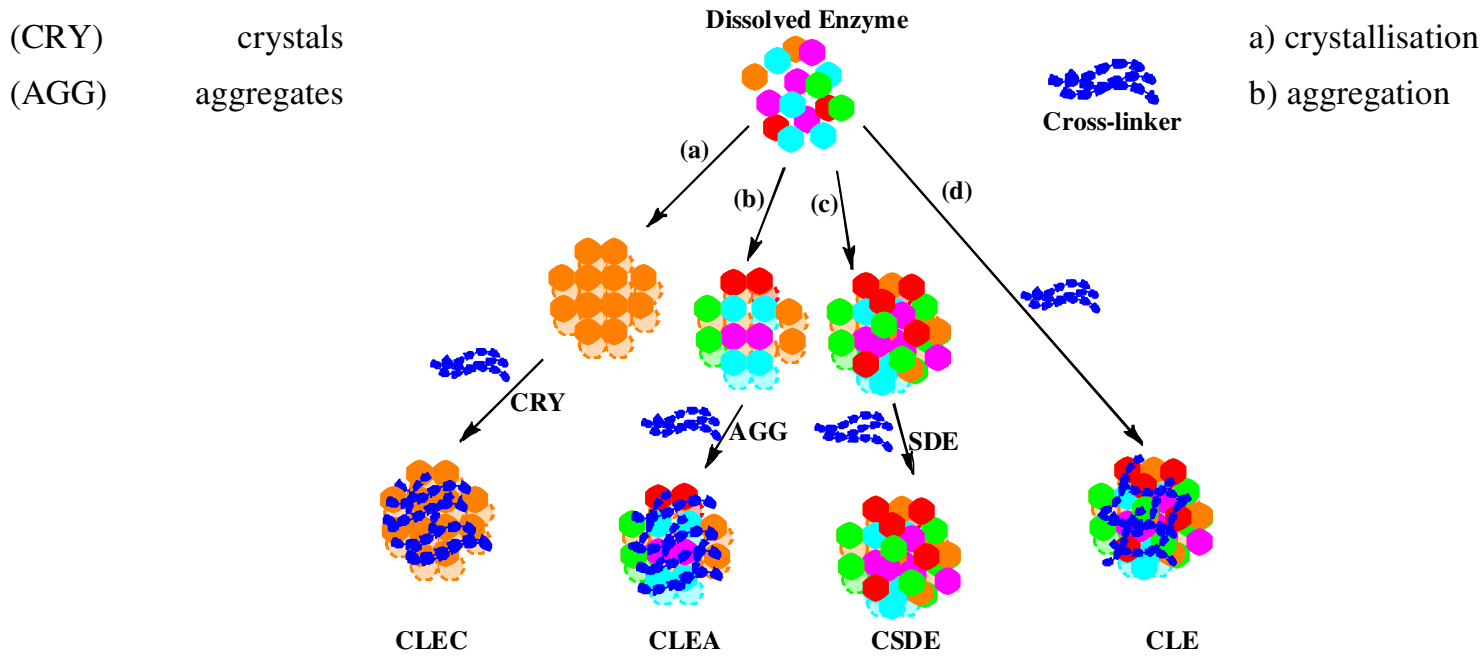

(SDE) spray-dried enzyme

c) spray-drying

d) direct-crosslinking

Figure 7. Formation of a cross-linked enzyme crystal (CLEC), a cross-linked enzyme aggregate (CLEA), a cross-linked spray-dried enzyme and a cross-linked dissolved enzyme (CLE), adapted from ref. 169.

CLEAs have received increasing attention in recent years due to their facile preparation and as a cheaper alternative to expensive supports ${ }^{170}$ they achieve higher volumetric activities (10-1000 U/g time higher) than carrier bound enzymes. ${ }^{178}$ The most efficient of the CLEA methods is the physical aggregation of enzymes followed by chemical crosslinking. ${ }^{179}$ Enzymes which have been successfully immobilised using cross-linking enzyme methodology include horseradish peroxidase, ${ }^{180}$ lipases, ${ }^{181-185}$ nitrilase, ${ }^{186}$ and esterases. ${ }^{187}$ 


\subsection{Practical applications of cross-linked enzyme aggregates}

One example which demonstrates the aforementioned advantages of immobilisation is the immobilisation of oxynitrilases. $(R)$-Oxynitrilases catalyse the hydrocyanation of aldehydes to form a wide range of $(R)$-cyanohydrins with high enantioselectivity. ${ }^{188-190}$ These reactions are typically performed in an aqueous organic two-phase system, in which the enzyme resides in the aqueous phase and the reactants and products are dissolved in the organic phase. The resulting low reactant concentration in the aqueous phase suppresses the un-catalysed background reaction that otherwise would decrease the enantiopurity of the products. ${ }^{188-190}$ Free $(R)$-oxynitrilases suffer from rapid deactivation, low substrate loading and poor recyclability. ${ }^{188,190}$

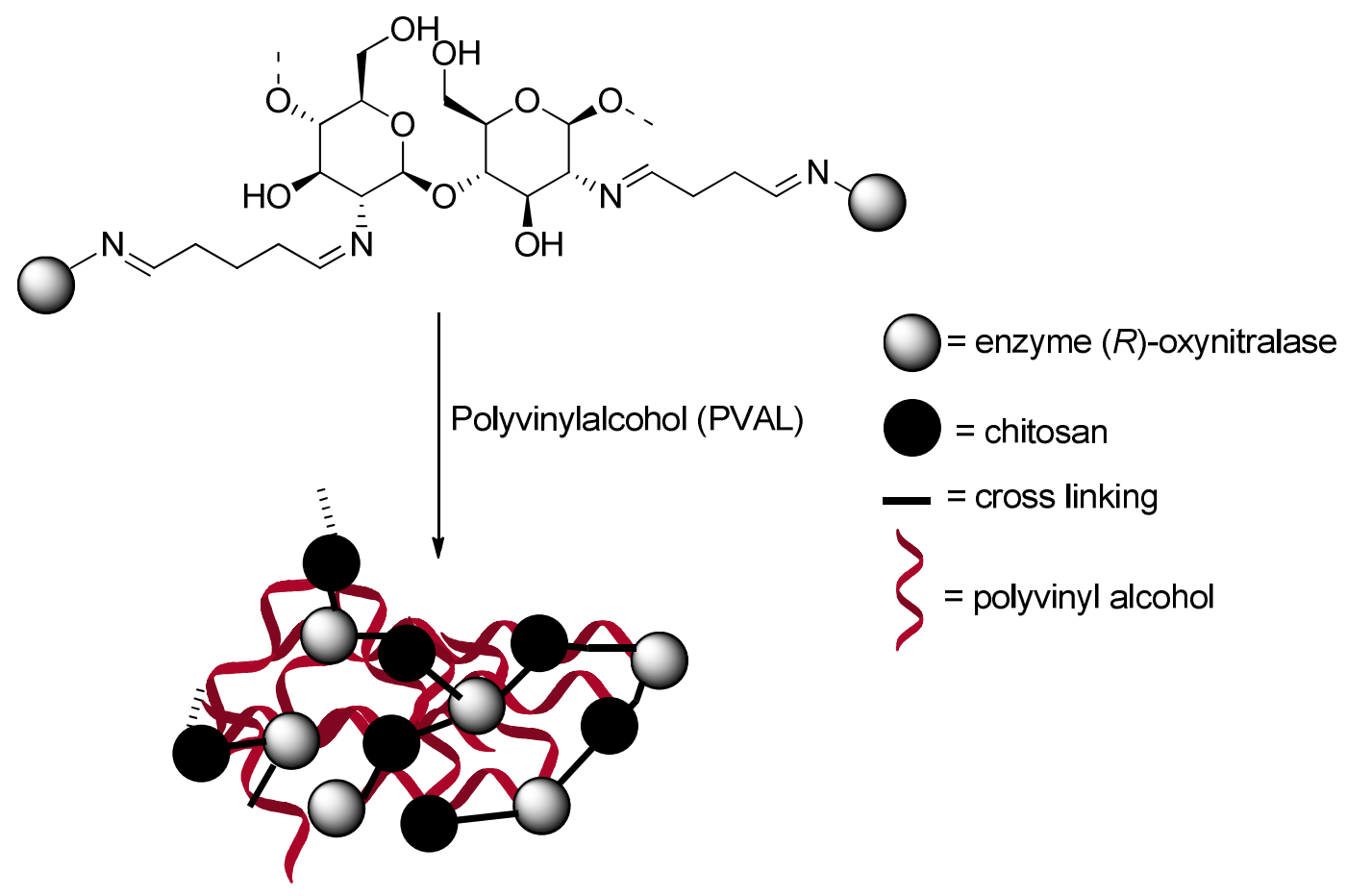

Figure 8. Adapted from ref. 191.

As is evident from Table 7 by modifying the enzyme through cross-linking and entrapping (Figure 8) ${ }^{191}$ an improved result was obtained, regarding efficiency as well as yield and enantioselectivity. The desired $(R)$-mandelonitrile 11 was obtained with $94 \%$ e.e. and $93 \%$ yield (Table 7, entry 2). ${ }^{190}$ Furthermore, even after reusing the lens-shaped catalysts 20 times, no decrease in conversion was observed. In contrast, the e.e. slightly increased from $91 \%$ e.e. to $95 \%$ e.e. This might be due to an increased stabilisation of the enzyme within the hydrogel matrix. ${ }^{190-191}$ A further example of the synthetic utility of CLEAs is demonstrated by Cao et al. ${ }^{192}$ Penicillin G acylase is widely used in the industrial synthesis of Ampicillin 12. All viable syntheses involve an activated side-chain donor such as D-phenylglycine amide 13 which acylates 6-APA 14 in the presence of penicillin acylase in a kinetically controlled reaction; water is the reaction medium of choice. 
Table 7. Entrapped biocatalysts in asymmetric hydrocyanation

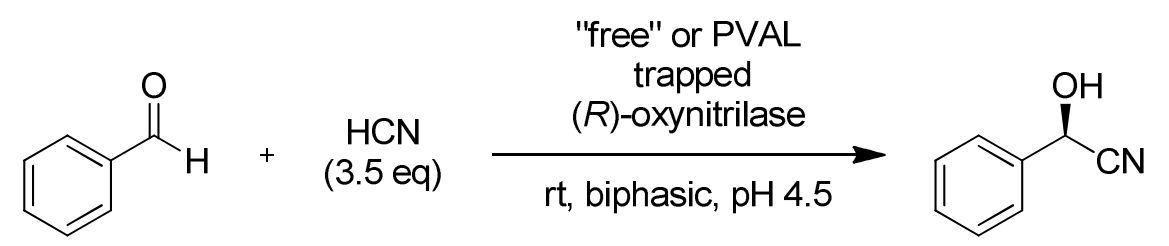

11

\begin{tabular}{l|lllll}
\hline Entry & Type of oxynitrilase & U per mmol & Organic solvent & $\begin{array}{l}\text { Yield } \\
(\%)\end{array}$ & $\begin{array}{l}\text { e.e. } \\
(\%)\end{array}$ \\
\hline $\mathbf{1}$ & free & 15 & MTBE/hex & 85 & 95 \\
$\mathbf{2}$ & Entrapped (8) & 15 & MTBE/hex & 93 & 94 \\
$\mathbf{3}$ & Entrapped (40) & 150 & MTBE/hex & 74 & 91 \\
$\mathbf{4}$ & Entrapped (40) & 75 & EtOAc & 62 & 93 \\
$\mathbf{5}$ & Entrapped (40) & 75 & MTBE/ & 70 & 92 \\
$\mathbf{6}$ & Entrapped (40) & 100 & $i$-Pr 2 & 84 & 99 \\
\hline
\end{tabular}

Table 8. Ampicillin synthesis catalysed by different Penicillin G Acylase preparations ${ }^{192}$<smiles>NC(=O)[C@H](N)c1ccccc1</smiles>

13<smiles>CC1(C)S[C@@H]2[C@H](N)C(=O)N2[C@H]1C(=O)O</smiles>

14

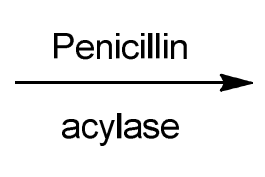

Relative

\begin{tabular}{c|cc}
\hline Biocatalyst & Conversion $(\%)$ & $\begin{array}{c}\text { Relative } \\
\text { productivity }\end{array}$ \\
\hline Free enzyme & 88 & 100 \\
CLEC & 72 & 39 \\
T-CLEA & 85 & 151 \\
PGA-450 & 86 & 0.8 \\
\hline
\end{tabular}<smiles>CC1(C)SC23[C@H](C(=O)N2[C@H]1C(=O)O)[C@H](NC(=O)C(N)c1ccccc1)SC3(C)C</smiles>

12 
Table 9. Synthesis of Ampicillin 12 catalysed by T-CLEA in organic solvents ${ }^{192}$

\begin{tabular}{c|cc}
\hline Solvent & Log P & Conversion \\
\hline Triglyme & -1.8 & 5 \\
2-Methoxyethyl ether & -1.3 & 11 \\
1,2-Dimethoxyethane & -0.8 & 10 \\
Acetonitrile & -0.4 & 17 \\
2-Ethoxyethyl ether & -0.3 & 25 \\
2,2-Dimethoxypropane & -0.2 & 56 \\
tert-Butyl alcohol & 0.8 & 18 \\
tert-Amyl alcohol & 1.4 & 33 \\
\hline
\end{tabular}

A major problem of such schemes is the competing irreversible hydrolysis of the acyl donor as well as the product. ${ }^{193}$ A simple solution would be to perform the reaction in an organic medium, however, the free enzyme is known to have a limited thermal stability and a very low tolerance toward organic solvents. ${ }^{192}$ As is evident from Table 8, immobilisation by CLEA improved the activity when compared to the free enzyme. ${ }^{192}$ Free penicillin $\mathrm{G}$ acylase is readily and irreversibly deactivated by organic solvents. However, as is apparent from Table 9 immobilised penicillin acylase is active in the synthesis of ampicillin in a broad range of organic solvents; no correlation between $\log \mathrm{P}$ and conversion was observed. ${ }^{192,194,195}$

\section{Genetic Engineering of Enzymes}

Enzymes have evolved over millions of years to react in a physiological environment, on a narrow range of natural substrates and typically at low concentrations. However, particularly on an industrial scale, biocatalysts are required to operate on a range of non-natural substrates and in difficult reactions conditions i.e. extremes of temperature, $\mathrm{pH}$, concentration and pressure with repeated and prolonged use. Furthermore, they need to perform in non-aqueous solvents in order to facilitate substrate solubility and/or product extraction. It is not surprising that the majority of natural enzymes do not meet these requirements. Modification of the enzyme is required to provide the necessary stability and activity. Use of chemical and/or physical enzyme engineering techniques is one solution (Section 1.4). However, enzyme engineering requires the enzyme to already possess relatively high substrate selectivity, and, is somewhat limited in the improvements it can make. Genetic engineering of the enzyme is required to alter the stereoselectivity, substrate scope and/or improve the enzyme activity. The early 1990s saw the development of new approaches to the enzyme optimisation technologies methods with the emergence of gene library generation via DNA shuffling ${ }^{196,197}$ and PCR techniques. ${ }^{198}$ Two principal processes routinely used to achieve this are rational design and directed evolution. 


\subsection{Rational design and directed evolution}

An overview of rational design is depicted in Figure $9 ;{ }^{199}$ in rational protein design, mutants are planned on the basis of their protein structure. They are prepared by site directed mutagenesis. Following transformation into the host expressing organism e.g. E. coli, the variantis expressed, purified and analysed for the desired traits.

Comprehensive overviews of the influence of rational design on protein activity are available. $^{200-202}$ Some specific examples include the employment of rational design to increase the stability of enzymes by the introduction of proline residues, ${ }^{203,204}$ disulfide bonds, ${ }^{205}$ or mutation towards the consensus for a given enzyme family. ${ }^{206,207}$ Rational design has also been employed to alter cofactor specificity ${ }^{208-211}$ and modify enzyme specificity by a redesign of the substrate binding site, ${ }^{212-215}$ or changing the position of a charged residue to favour transformation of one substrate over another. ${ }^{216,217}$ Unlike directed evolution, improvements or inversion of enantioselectivity are rarely reported by groups examining protein engineering through rational design.

Directed evolution is employed to improve the stability and enzymatic function of proteins by repeated rounds of mutations and selection and this method has been thoroughly reviewed in the literature. $^{218-222}$ Directed evolution commences with a parent protein and an engineering goal such as enhanced selectivity or protein stability on a particular substrate. The parent gene is subjected to a number of random point mutations to produce a library of mutants. Proteins encoded by these mutant genes are then produced and screened for the desired function and the proteins are used as the parents for another round (Figure 9). The beneficial mutations are collected until the desired outcome is achieved or no other improvements are practically feasible. This methodology requires careful experimental design, for a protein that is composed of 350 amino acids, 20,400 possible sequences exist. A single mutation of an amino acid would lead to 7,600 variants, a double mutation would lead to 144,000 variants. Initially scientists attempted to develop a screening protocol for the result of each mutation, however, it was clear this was not possible. Codexis tried to tackle this issue with the development of an algorithm named Pro-SAR (protein sequence activity relationship) whereby all mutations were assigned either beneficial, neutral or deleterious properties based on the function for which they were being designed. Another approach to reduce the vast array of possible mutation was to only perform mutations at the enzyme active site. 


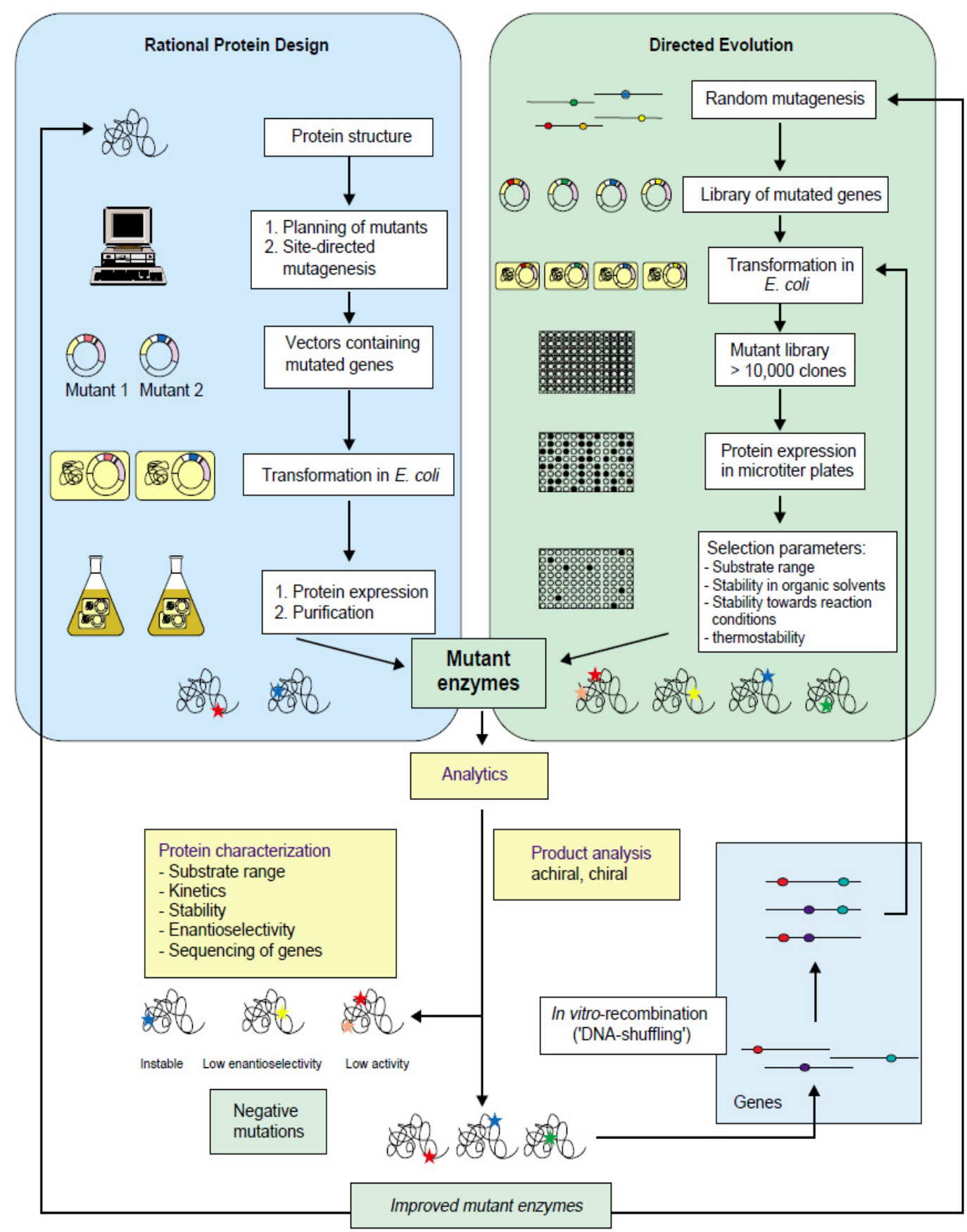

Figure 9. Reproduced from ref. 199.

\subsection{Practical applications of genetically modified enzymes}

Directed evolution has been utilised to significantly improve the enantioselectivity (Figure 10, example A and B), catalytic activity (Figure 10, example B) and substrate concentration (Figure 10, example $\mathrm{C}$ ) of a number of enzymes; inversion of enantioselectivity has also been obtained by directed evolution (Figure 10, example D). Examples of each of these are described in Figure 10. 


\section{Improved enantioselectivity and catalytic activity}

Example A:223
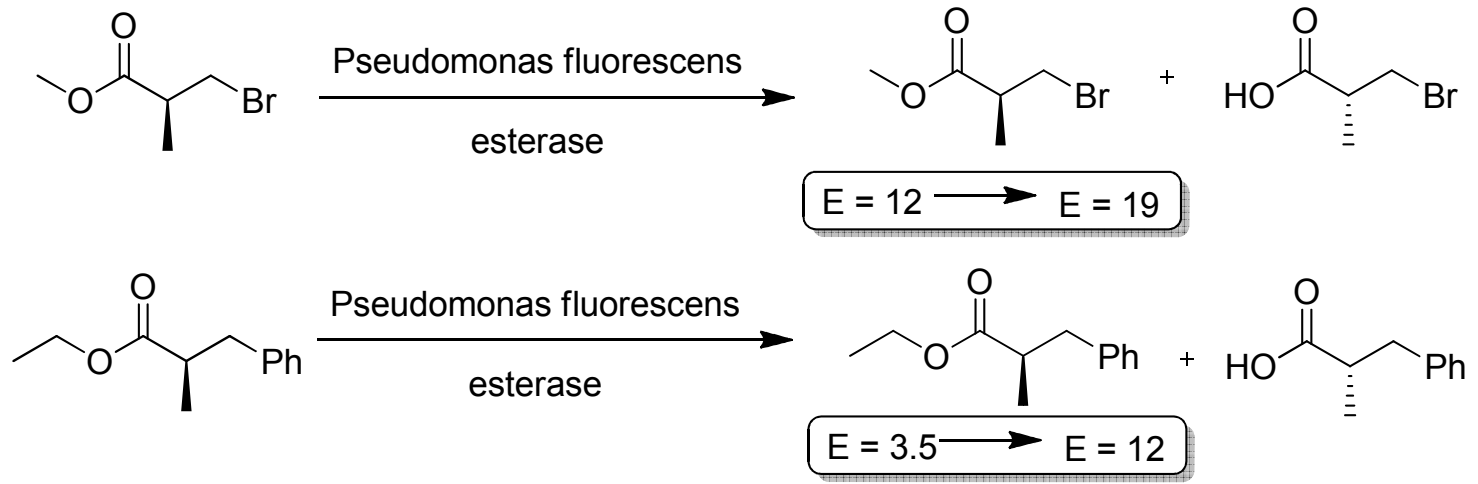

Example B: ${ }^{224-226}$

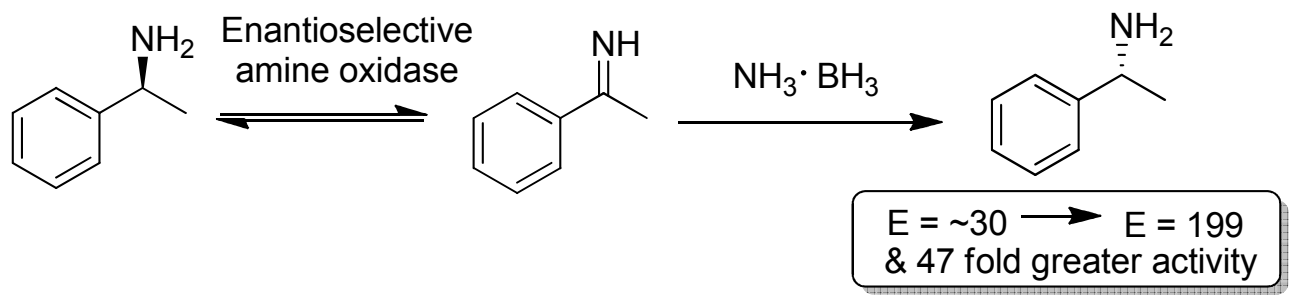

Improved enantioselectivity ${ }_{1}$ catalytic activity at increased substrate concentration Example C: ${ }^{227}$

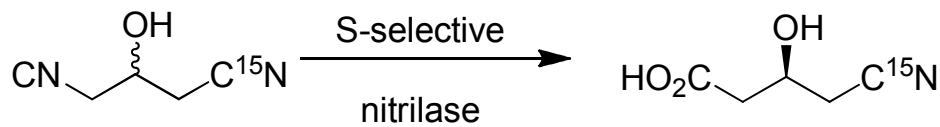

\section{Inversion of enantioselectivity}

Example D: ${ }^{228}$

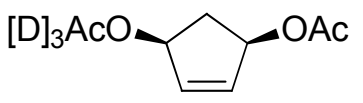

Wild type

Bacillus subtilis

Lipase<smiles>CC(=O)OC1C=CC(OC(C)(C)C)C1</smiles>

$38 \%$ ee<smiles>CC(=O)O[C@H]1C=C[C@@H](O)C1</smiles>

$[\mathrm{D}]_{3} \mathrm{AcO}$,

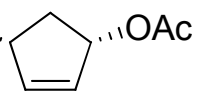

$15 \%$ ee

Figure 10 


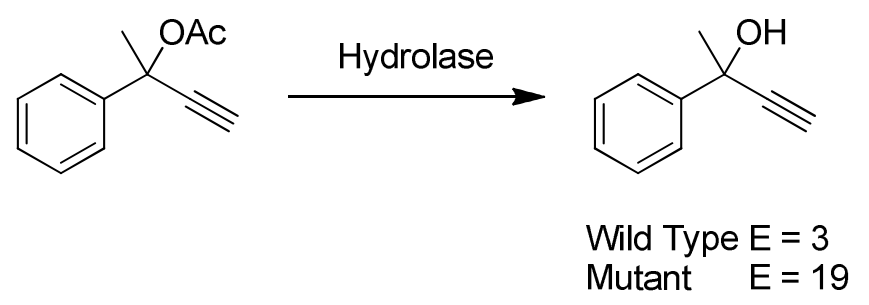

\section{Scheme 8}

An excellent example of the application of molecular modelling, and how a small change in the genetic sequence of an enzyme can dramatically affect the activity of an enzyme was demonstrated by Roticci et al. ${ }^{240}$ It was shown that the enantioselectivity of Candida antarctica B lipase-catalysed resolution of 1-chloro-2-oktanol was improved from $\mathrm{E}=14$ to 28 by a single amino acid exchange as predicted by molecular modelling. ${ }^{240}$

\section{Kinetic and Dynamic Kinetic Resolution-a Biocatalytic Perspective}

Despite the impressive progress in asymmetric synthesis, the resolution of racemates is one of the main methods to obtain a single enantiomer. ${ }^{16,17}$ The resolution of enantiomers has been performed by preferential crystallisation, ${ }^{241-245}$ diastereomer crystallisation, ${ }^{245-247}$ kinetic and dynamic kinetic resolutions. For both reaction types, kinetic and dynamic kinetic resolution, a basic criterion has to be fulfilled; thus, in order to obtain any resolution at all, the reaction rate (Figure 12) of one enantiomer has to be much faster than that of the other, i.e. $k_{\text {Fast }}>k_{\text {Slow. }}{ }^{248,249} \mathrm{~A}$ common example of kinetic resolution is the reaction of a racemic alcohol with an acyl donor in the presence of an enzyme. The resolution of racemates employing enzymatic means has become an important tool for resolving enantiomers achieving enantiopure biologically active compounds. ${ }^{11-15}$

\subsection{Kinetic resolution}

Kinetic resolution is a process in which one of the enantiomers of a racemic mixture is more readily transformed into a product than its mirror image. ${ }^{250}$ The principal requirement of this process is that the rate of transformation of the $R$ enantiomer is not equal to the rate of transformation of the $S$ enantiomer (Figure 11). 


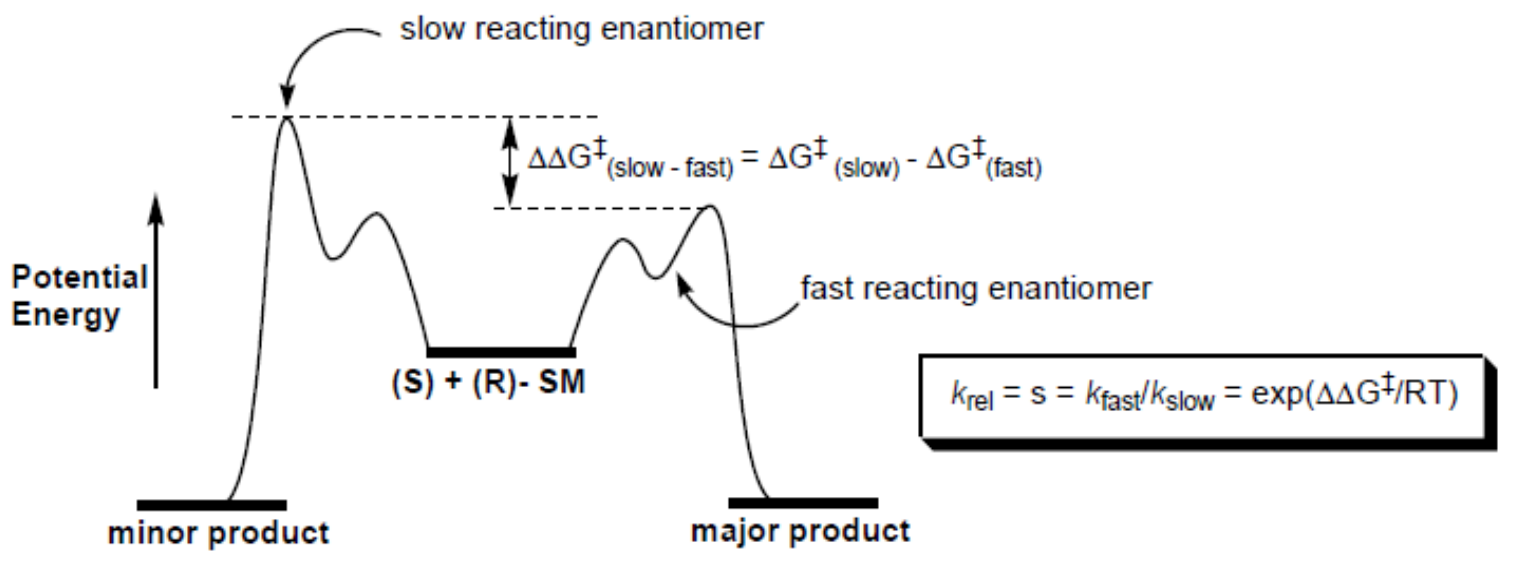

\section{Kinetic resolution}

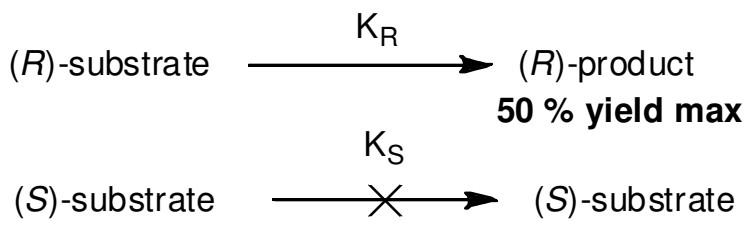

\section{Figure 11}

In enzymatic kinetic resolution a racemic substrate undergoes an enzymatic resolution process wherein chiral discrimination of enantiomers takes place. In an ideal enzymatic kinetic resolution process a maximum yield of $50 \%$ can be achieved which is a severe limitation of this protocol. Thus, the resolution is usually accompanied by additional processing such as separation, racemisation and recycling of unwanted enantiomers which can contribute to high processing costs. A vast array of examples of enzymatic kinetic resolution are available in the literature and these have been reviewed in detail. ${ }^{251-253}$ Figure 12 describes examples of enzymatic kinetic resolution of an achiral substrate by acylation, deacylation, oxidation, and reduction. 


\section{Biocatalytic kinetic resolution by acylation and deacylation}

Example A: $:^{254}$<smiles>O[C@H]1Cc2cccc3cccc1c23</smiles>

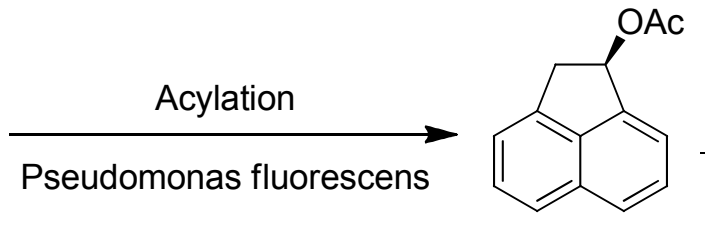

$94 \%$ ee

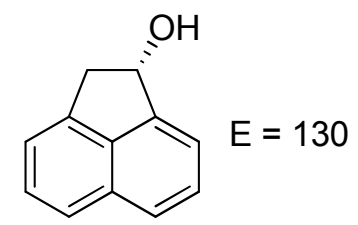

$97 \%$ ee

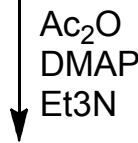<smiles>CC(=O)OC1Cc2cccc3cccc1c23</smiles>

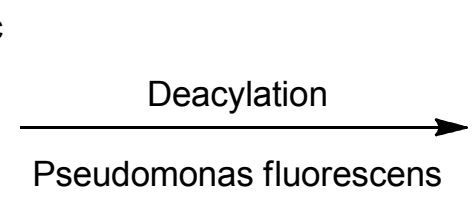<smiles>OC1Cc2cccc3cccc1c23</smiles><smiles>C=C[Se]O[Na]</smiles>

$99 \%$ ee

\section{Biocatalytic kinetic resolution by oxidation}

Example B: ${ }^{256}$

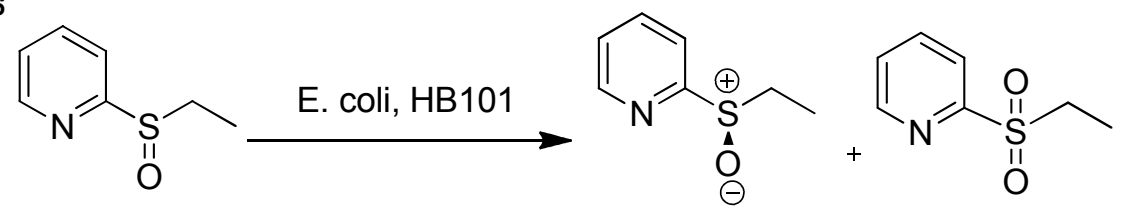

$44 \%$ yield $>98 \%$ ee

Example C: ${ }^{255}$<smiles>CCC(=O)C(C)c1ccccc1</smiles>

Mutant Baeyer-Villiger monoxygenase (PAMO)/Buffer

G6P/G6PDH/NADP ${ }^{+}$

$14 \mathrm{~h}, 15^{\circ} \mathrm{C}, \mathrm{pH} 8$<smiles>CCC(=O)[C@H](C)c1ccccc1</smiles>

$98 \%$ ee<smiles>CC(=O)O[C@@H](C)c1ccccc1</smiles>

$97 \%$ ee

\section{Biocatalytic kinetic resolution by reduction}

Example D: ${ }^{257}$<smiles>CCC1CCC(=O)C1S(=O)(=O)O</smiles>

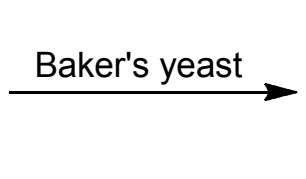<smiles>CC[C@@H]1CCC(=O)C1S(=O)O[Na]</smiles><smiles>CCC1CC[C@H](O)[C@H]1[Se]OP(=O)(O)Oc1ccccc1</smiles>

$47 \%$ yield $>95 \%$ ee

\section{Example E:258}<smiles>CC(O)c1ccccc1</smiles>

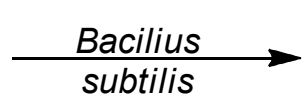

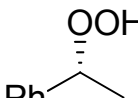<smiles>C[C@H](O)Pc1ccccc1</smiles>

$99 \%$ ee $\quad 20 \%$ ee $94 \%$ conversion

\section{Figure 12}




\subsection{Dynamic kinetic resolution}

When a kinetic resolution process is accompanied by racemisation of the substrate this is termed dynamic kinetic resolution (DKR). The driving force for a dynamic kinetic resolution process is that there is an increase in entropy when two enantiomers are mixed. ${ }^{259}$ Therefore, the following elements are required in order for an efficient dynamic kinetic resolution process to occur: the kinetic resolution step has to be irreversible, the $E$-value has to be at least 30, preferably between 50 and 100, and the rate of racemisation has to be greater than the rate of reaction of the slow reacting enantiomer. In situ racemisation of the slow-reacting enantiomer leads to deracemisation by dynamic kinetic resolution and makes a theoretical yield of $100 \%$ possible (Figure 13). This makes DKR an attractive method to gain access to a desired enantiomer in high yield. Chemoenzymatic methods of DKR have been thoroughly reviewed. ${ }^{11,244,248,249,252,260-262}$

a) Racemisation

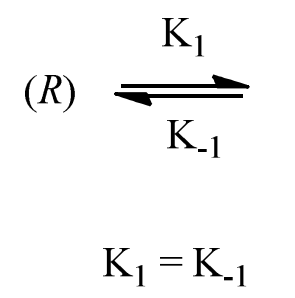

(S)

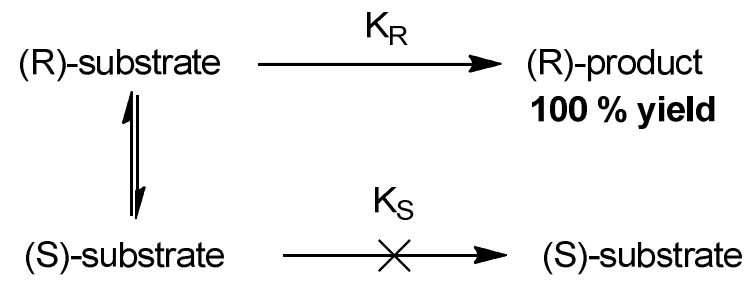

\section{Figure 13}

6.2.1. Dynamic kinetic resolution without metal catalysis. Zwanenburg et al. have classified the racemisation into different methods: i) thermal racemisation, ii) base-catalysed racemisation, iii) acid-catalysed racemisation, iv) racemisation via Schiff bases, v) enzyme-catalysed racemisation, vi) racemisation via redox and radical reactions. ${ }^{263}$ Base catalysed racemisation is one method of racemisation and it involves the removal of hydrogen from the chiral centre to form a carbanion, which makes chiral compounds which possess an acidic proton ideal substrates for this process. The resultant carbanion needs to be stabilised by an electron withdrawing group such as keto, nitro, nitrile (Figure 14a) or by reversible elimination of a $\beta$-substituent (Figure 14b). Oxidation and reduction reactions are also employed to produce racemates, oxidation removes a hydrogen from a chiral centre and subsequent reduction or hydrogenation will lead to racemate formation (Figure $14 \mathrm{c}) .^{263}$ 


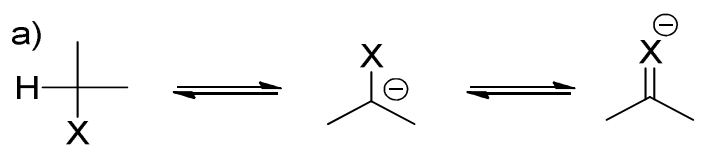

b)

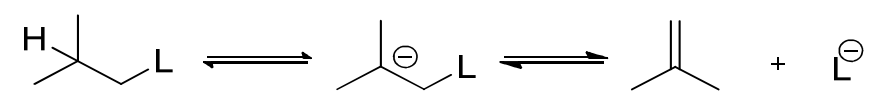

c)

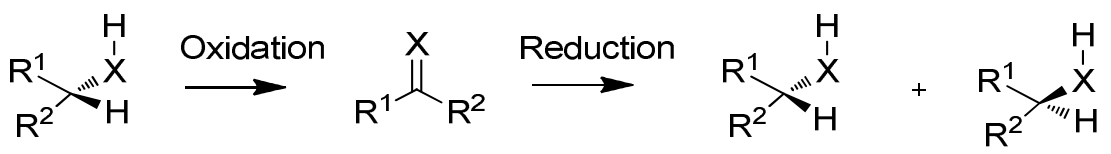

\section{Figure 14}

Lipase-mediated aminolysis has been converted to a DKR process by the incorporation of racemisation agents such as salicylaldehyde and pyridoxal 15 via the formation of an imine intermediate 16 (Scheme 9). ${ }^{253}$ Enzymatic dynamic kinetic resolution has been performed with thioesters due to the high acidity of their $\alpha$-protons (Scheme 10). ${ }^{264}$

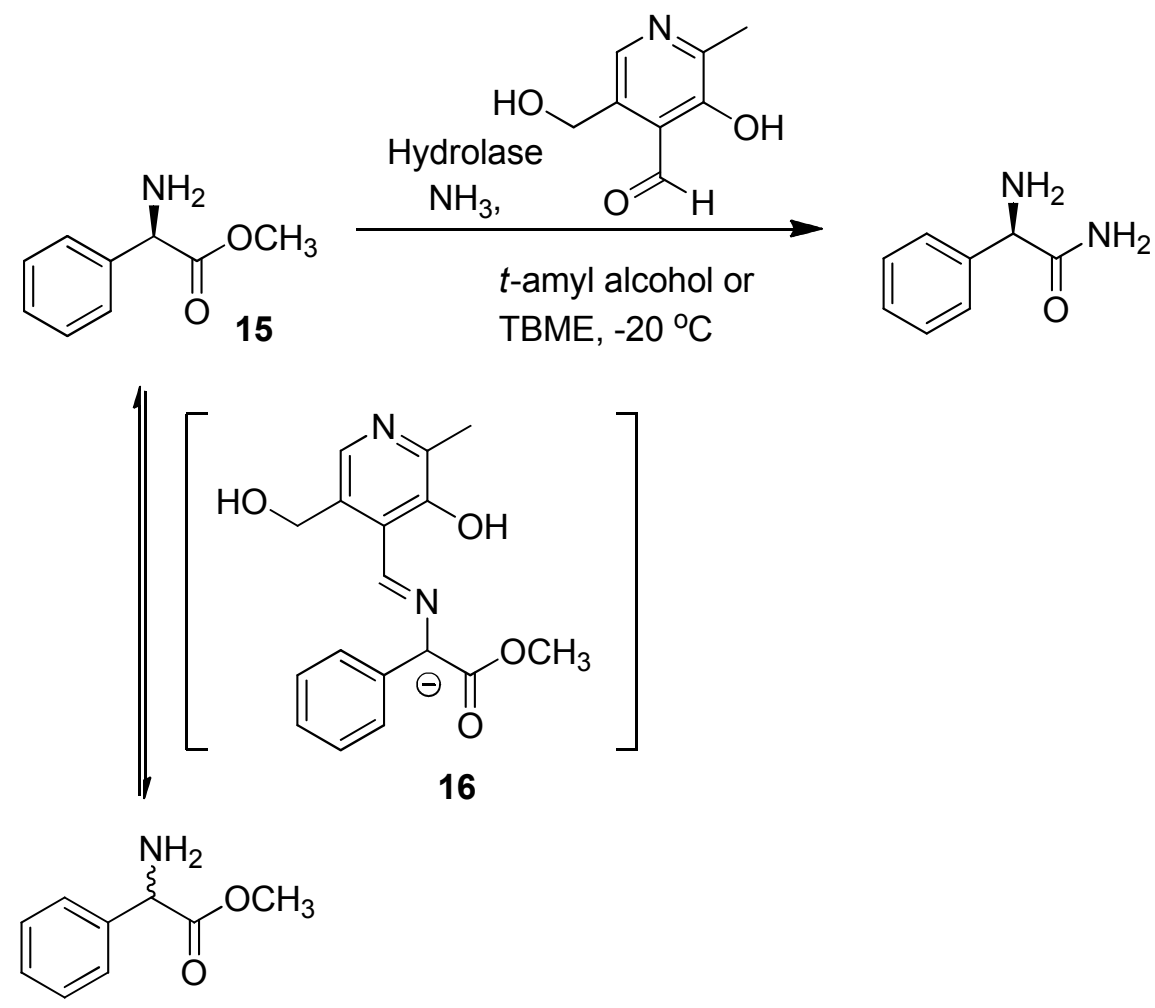

\section{Scheme 9}


<smiles>[R]SC(=O)C([X])C</smiles>

\section{Scheme 10}

Heterocycles such as pyranones and pyrrolidinones have proved ideal substrates for dynamic kinetic resolution by enzymatic means. Racemisation occurs spontaneously due to the inherently labile nature of these compounds (Scheme 11). ${ }^{265} \mathrm{~A}$ similar observation was observed in the kinetic resolution of 8-amino-5,6,7,8-tetrahydroquinoline 17. A spontaneous DKR process was observed due to formation of an intermediate $\mathbf{1 8}$ in the reaction and reformation via an imine mechanism of the racemic hydroxy pyrrolone $\mathbf{1 7}$; moderate to good yields are reported (Scheme 11). ${ }^{266}$

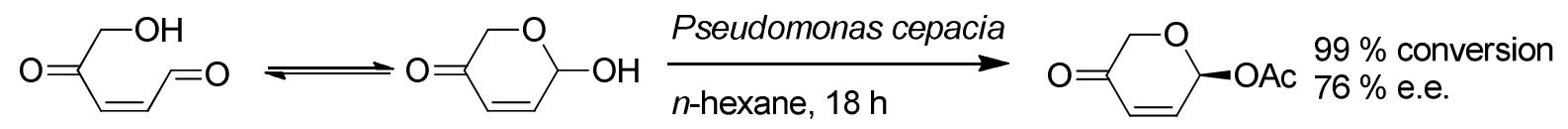<smiles>[R]N1C(=O)C=CC1O</smiles>

17

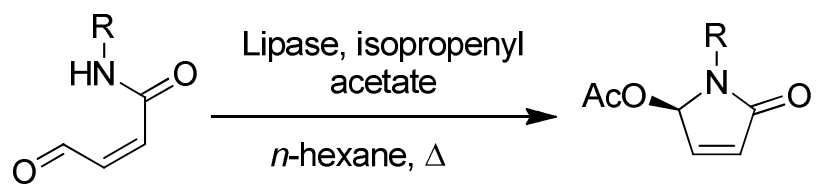

18

\section{Scheme 11}

An unusual DKR process was reported by Bertrand et al. whereby an in situ free radical mediated racemisation of amines via an alkylsulfanyl radical was employed with lipase-mediated transesterification up to $81 \%$ conversion with $99 \%$ e.e. reported. ${ }^{267}$ Immobilised lipase-catalysed DKR yielding optically active cyanohydrin acetates were obtained in good yields and up to $93 \%$ e.e. employing the use of a silica-supported ammonium hydroxide as the racemisation catalysts (Scheme 12). ${ }^{268}$

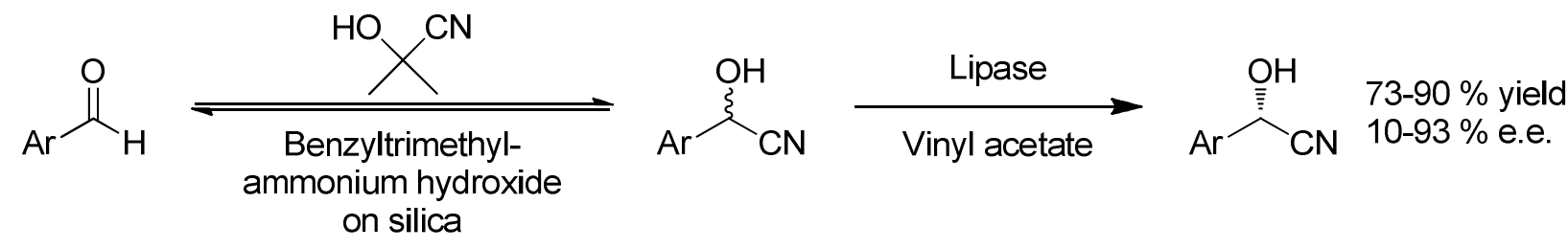

\section{Scheme 12}


The nitroaldol product of the Henry reaction is an ideal substrate for a dynamic kinetic resolution process as the resultant $\beta$-nitroalcohols possess a highly acidic proton $\alpha$ to the nitro group which is easily removed by base. Vongvilai et al. through a one-pot nitroaldol reaction in the presence of triethylamine, acyl donor and Pseudomonas cepacia, obtained a range of nitroalcohols in good yields and enantioselectivities (Scheme 13). ${ }^{269,270}$

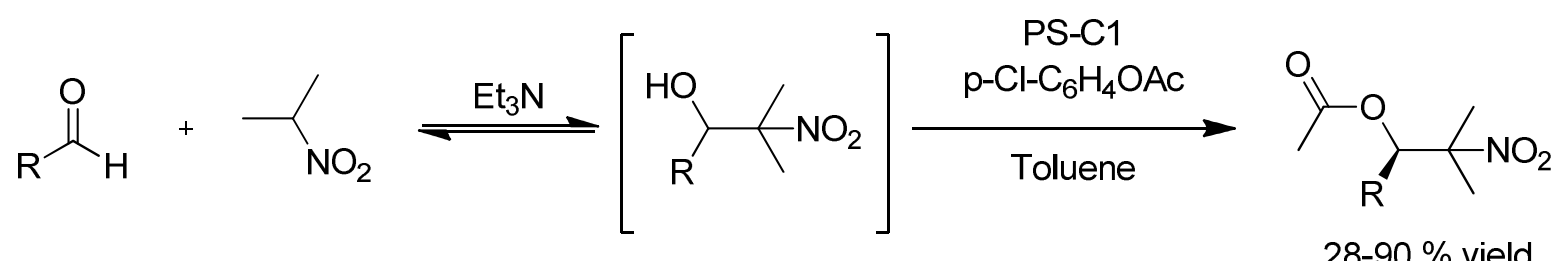
$46-99 \%$ e.e.

\section{Scheme 13}

Maguire et al. reported efficient spontaneous dynamic kinetic resolution of 2benzenesulfonylcyclopentanone and 2-benzenesulfonylcyclohexanone under Baker's yeast reduction conditions both in organic and aqueous solvents to form the corresponding cycloalkanols in excellent enantiopurity; however, reduction of larger ring sizes was less efficient (Figure 15). ${ }^{271}$

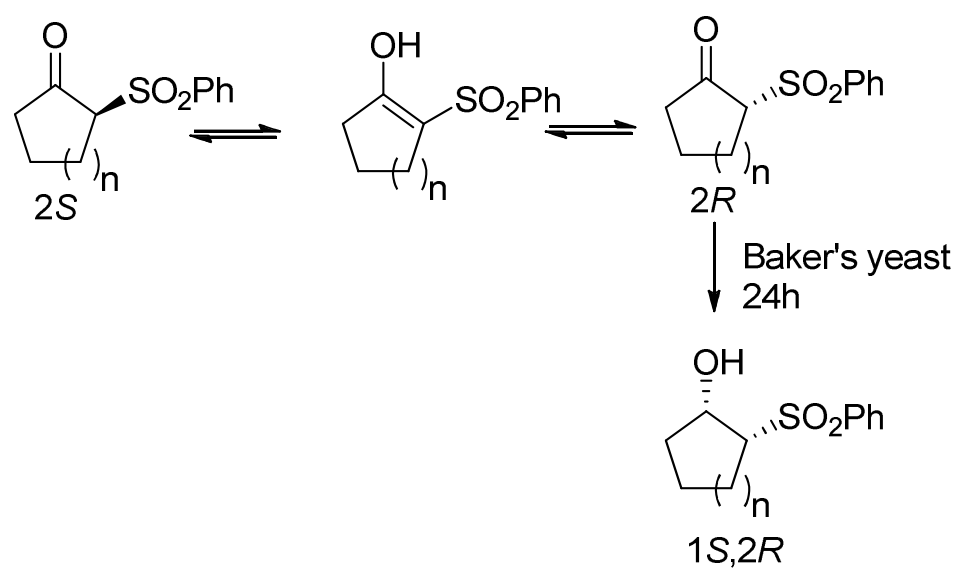

\begin{tabular}{c|ccc}
\hline $\mathrm{n}$ & $\begin{array}{c}\% \\
\%\end{array}$ & d.r. \\
& Conversion & e.e. & \\
\hline $\mathbf{1}$ & 95 & $>98$ & $98: 2$ \\
$\mathbf{2}$ & 85 & $>98$ & $>98: 2$ \\
$\mathbf{3}$ & 11 & - & - \\
$\mathbf{4}$ & 0 & - & - \\
\hline
\end{tabular}

\section{Figure 15}


6.2.2 Dynamic kinetic resolution with metal catalysts. In recent years, chemoenzymatic DKR of secondary alcohols has been a rapidly evolving field of research. Metals such as rhodium, iridium and ruthenium are known to racemise secondary alcohols, for the in situ conversion of unwanted enantiomers to products, but only a few of these metals have proved compatible with enzymatic reaction conditions, and these have been reviewed. ${ }^{250,272-281}$ The first example of a chemoenzymatic DKR of secondary alcohols was reported by Williams; a ruthenium catalyst was combined with a lipase to produce enantiopure acetate of 1-phenyl ethanol in $81 \%$ conversion and $96 \%$ e.e. $^{278}$ Bäckvall made significant improvements to this procedure by using immobilised Candida antarctica Lipase B and a ruthenium complex. An argon atmosphere was essential for high efficiency as a nitrogen atmosphere led to a $36 \%$ reduction in yield but the enantioselectivity was unaffected (Scheme 14). ${ }^{282}$

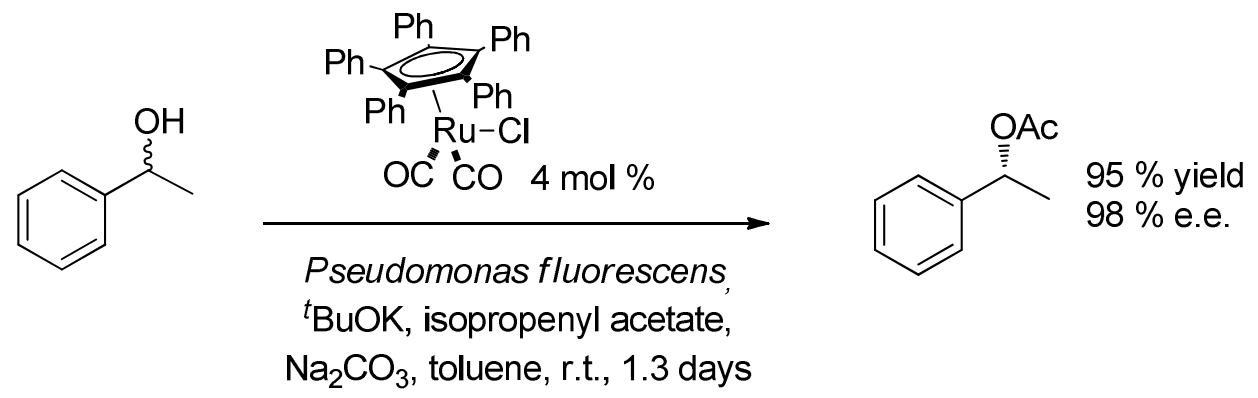

\section{Scheme 14}

Since these initial reports a vast array of secondary alcohols have been examined under ruthenium/lipase combination DKR conditions: allylic alcohols, benzoins, diols, hydroxyaldehydes, hydroxyacids, 1,2-diarylethanols, $\gamma$-hydroxy amides, $\beta$-hydroxylalkyl sulfones, and these have been reviewed. $^{250,272-281}$ It should be noted that vinyl acetate is incompatible with the ruthenium complexes explored, while isopropenyl acetate can be used with the majority of monomeric ruthenium complexes. $p$-Chlorophenyl acetate is the best acyl donor for the dimeric ruthenium complexes. $^{283}$ The racemisation mechanism, of ruthenium catalysed dynamic kinetic resolution of secondary alcohols proposed by Bäckvall et al. is depicted in Scheme $15{ }^{284}$ The ruthenium halide complex is activated by the substitution of chloride with tert-butanol; ligand exchange with the substrate alcohol leads to a second alkoxide intermediate which undergoes a hydride elimination to give the oxidised intermediate; insertion of the ketone into the $\mathrm{Ru}-\mathrm{H}$ bond produces the racemic alkoxide. $^{284}$ 

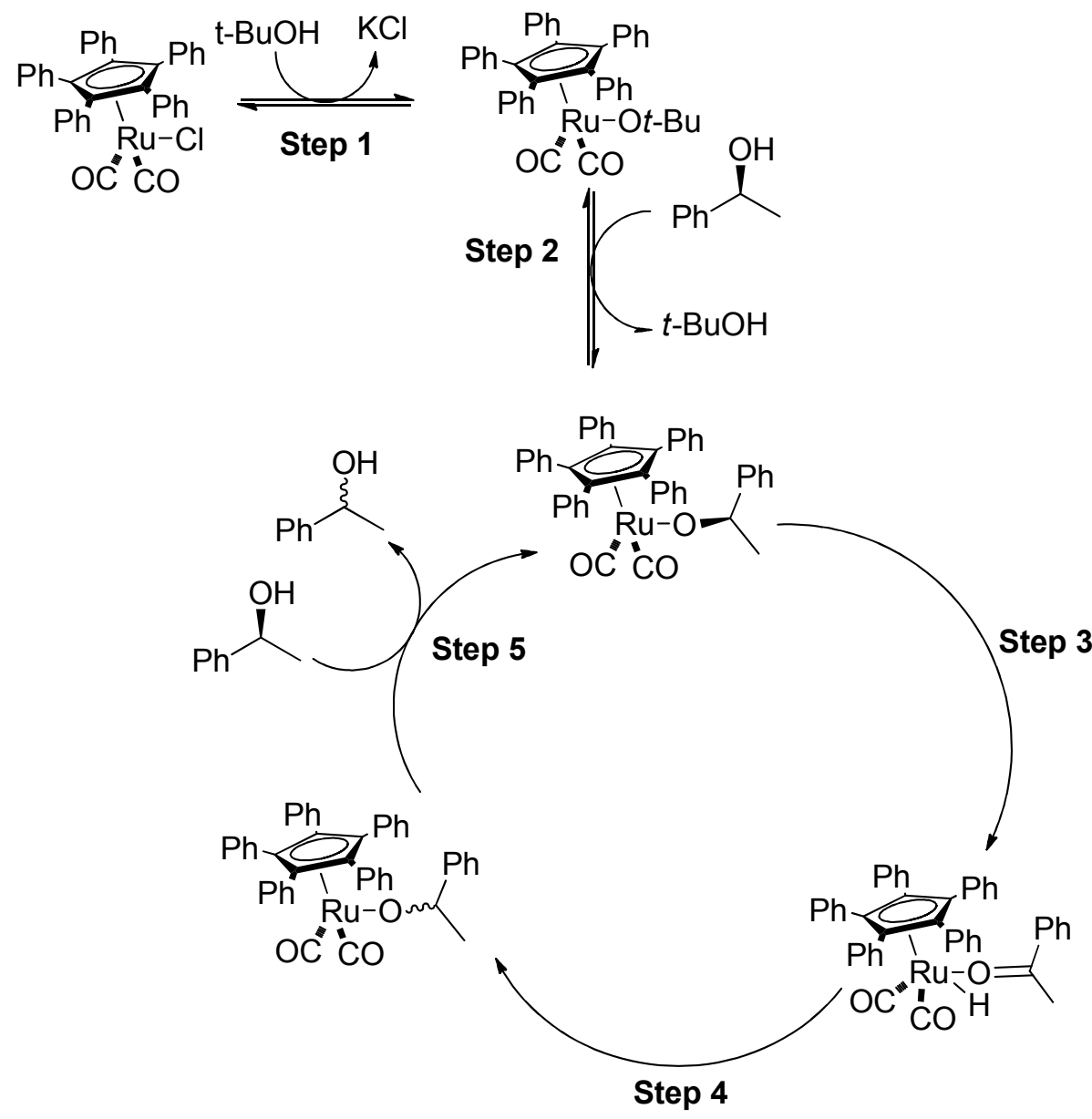

\section{Scheme 15}

Other metal/enzyme systems have provided a DKR system for the resolution of secondary alcohols. Aluminium is an attractive alternative to ruthenium as it is relatively cheap and widely available. Müller et al. examined several aluminium species and found that an $\mathrm{AlMe}_{3}-\mathrm{BINOL}$ complex led to racemisation of 1-phenyl ethanol in toluene at room temperature. This was subsequently coupled with Novozym $435^{\circledR}$ and excellent conversion and enantioselectivity was observed with a range of secondary alcohols. ${ }^{285}$ Vanadium has also been employed for the racemisation of allylic alcohols through the formation of allyl vanadate intermediates (Scheme $16) .^{286,287}$ 


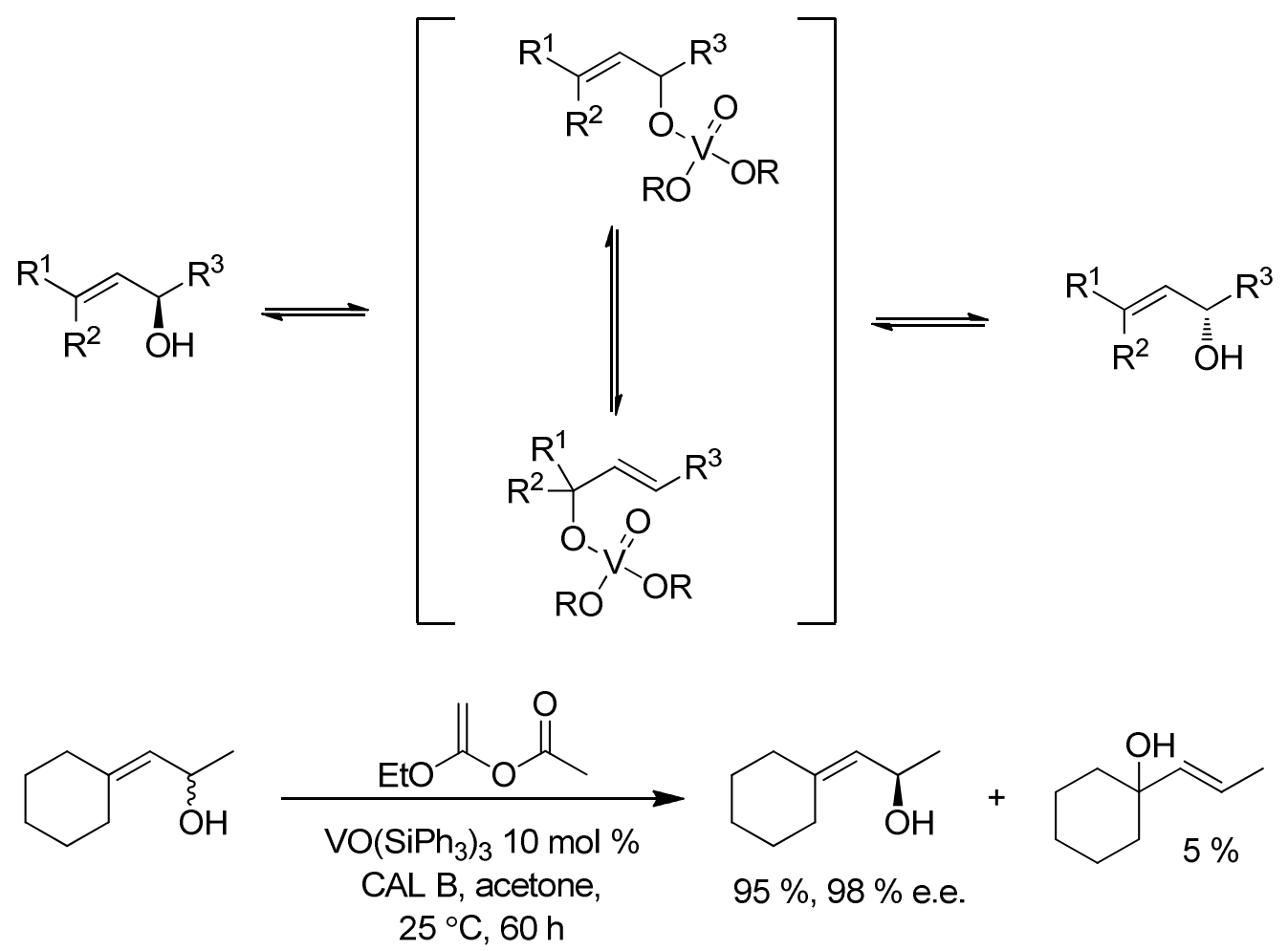

\section{Scheme 16}

Palladium metal has also been investigated as an amine racemisation catalyst. The first report described a palladium on charcoal mediated DKR with 1-phenylethylamine in triethylamine; reactions took 8 days at $50-55^{\circ} \mathrm{C}$, and poor yields are reported. ${ }^{288}$ Alkaline earth supports such as $\mathrm{BaSO}_{4}, \mathrm{CaCO}_{3}, \mathrm{CaCO}_{3}$ and $\mathrm{SrCO}_{3}$ have been employed in conjunction with palladium catalysts; The combination of palladium, supported on alkaline earth supports with a lipase resolves a range of benzylic amines as substrates to provide good conversions (up to $91 \%$ ) and enantioselectivities (99 \% e.e) under hydrogenolysis mediated conditions. ${ }^{286,289}$ Vos et al. expanded this study by the use of heterogeneous Raney ${ }^{\circledR}$ nickel and cobalt catalysts and achieved both excellent conversions and enantiopurities. ${ }^{290}$ The racemisation methodology of amines under hydrogenation in the presence of metal catalysis is depicted in Scheme $17 .^{290}$ 


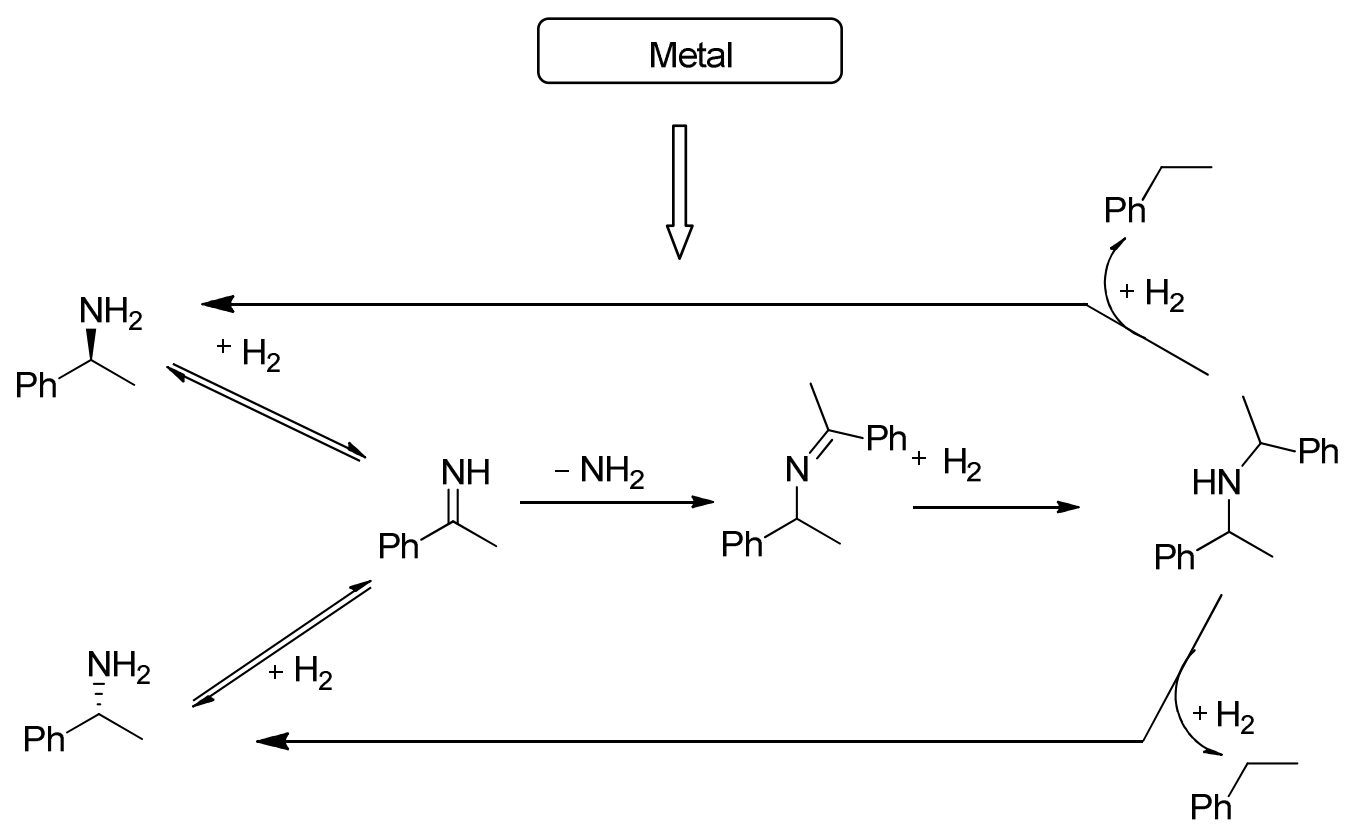

\section{Scheme 17}

Kim et al. reported the production of highly enantioenriched acetylated amines by lipase/palladium DKR catalysis in the presence of an acyl donor with the employment of ketoximes as starting materials under hydrogenation conditions (Scheme 18). ${ }^{291}$

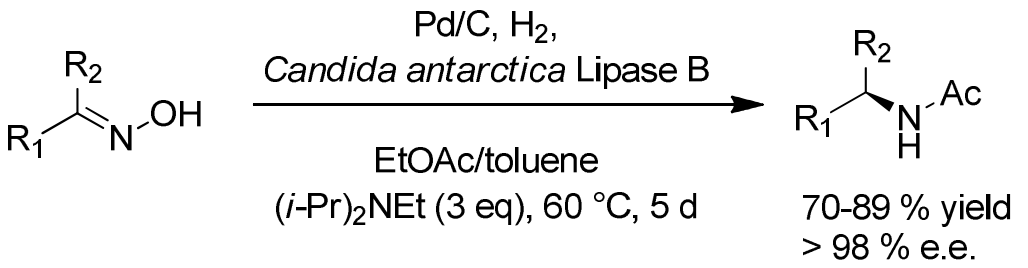

\section{Scheme 18}

\section{Baker's Yeast Mediated Resolution of Sulfur Containing Compounds}

\subsection{Introduction}

In 1874 the reducing action of Saccharomyces cerevisiae was first described in the literature by Dumas. $^{292}$ Baker's yeast was first applied industrially in 1997 in the synthesis of Trimegestone, a norsteroidal progestomimetic compound (Scheme 19). ${ }^{293}$ 

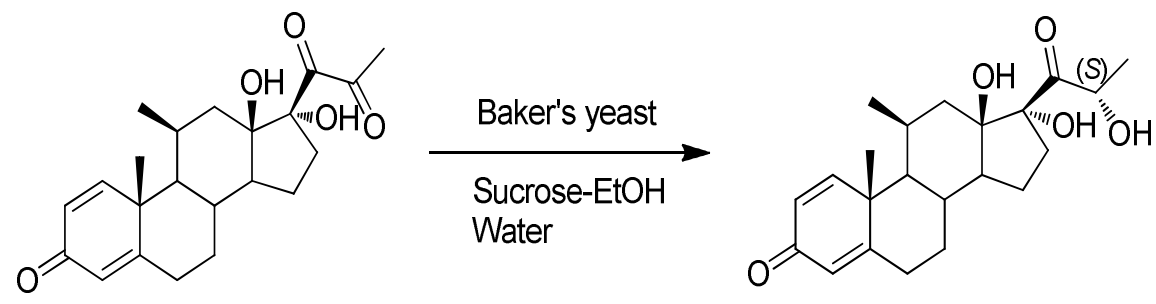

$49 \%$ yield

$99.5 \%$ e.e.

\section{Scheme 19}

Crocq et al. chose Baker's yeast due to its "si" selectivity in the reduction of prochiral ketones bearing a carbonyl function group at the $\alpha$ - or $\beta$-position. ${ }^{29,293-296}$ Baker's yeast has been used extensively on the laboratory scale to perform reductions and has several advantages with regard to industrial applications: no toxicity or ecotoxicity, a consistent quality, as a result of its use in the baking industry, and a very low price. Another advantage of whole cell systems such as Baker's yeast is that they do not need extra cofactors as they possess all the necessary enzymes for cofactor regeneration. 11,250,295,297-299 Dehydrogenases and reductases have been found to be the key enzymes responsible for catalytic activity in the reduction of carbonyl groups to hydroxyl groups. Alcohol dehydrogenases (ADHs) are responsible for the reduction of carbonyls, while enoate reductases (ERs) account for the reduction of 'activated' carbon-carbon double bonds. ${ }^{297,300}$ However, these enzymes require a nicotinamide cofactor, $\mathrm{NAD}(\mathrm{P}) \mathrm{H}$, from which a hydride is transferred to the substrate carbonyl carbon. The oxidised form of the cofactor, $\mathrm{NAD}(\mathrm{P})^{+}$is transformed back to its reduced form for the next cycle of the reduction process. The cofactor regeneration of alcohol dehydrogenase and enoate reductase in the biocatalytic reduction process with Baker's yeast is illustrated in Scheme 20. The cofactor is regenerated by glucose dehydrogenase $(\mathrm{GDH})$ which is already present in the cell, in the presence of the required cosubstrate such as glucose or ethanol. ${ }^{297,300}$ 

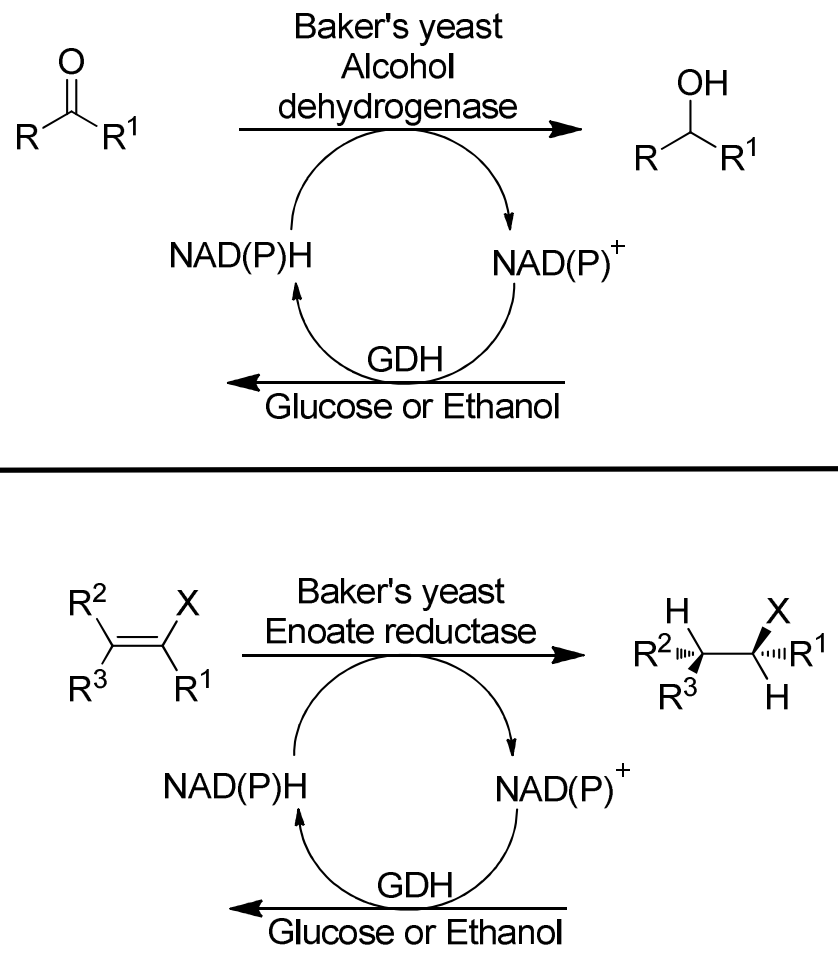

Scheme 20. Bioreduction of ketone and alkene groups by Baker's yeast.

The main drawback of Baker's yeast as a chemical tool is its low productivity, thus, requiring large amounts of Baker's yeast and highly dilute media. Moreover, the recovery of the product from the enzymatic medium can be tedious, particularly the filtration stage. Because these reactions require nicotinamide cofactors $(\mathrm{NADPH})$, the use of whole cells rather than isolated enzymes is preferred, to avoid the need for enzyme purification and cofactor regeneration. Enantioselectivity is governed by geometry of hydride addition and refers to the configuration of the newly created alcohol stereocentre and generally follows Prelog's rule with approach of the hydride from the " $r e$ " face of the carbonyl to give the $S$-enantiomer of the alcohol (Figure 16). ${ }^{11,250,295,297-299,301}$

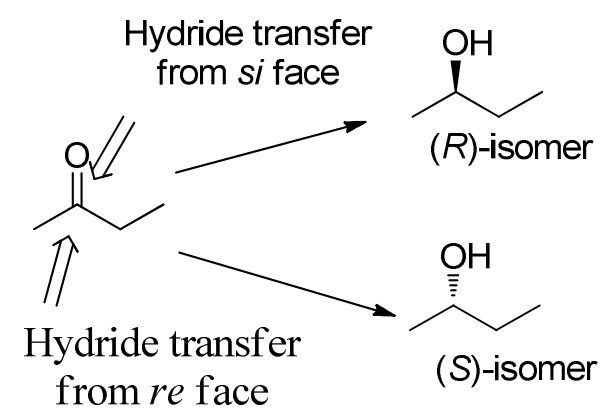

Figure 16. Baker's yeast reduction of carbonyl compounds follows Prelog's rule. 
In some cases, these reductions proceed smoothly to yield a single product; however, with more complex substrates, mixtures of stereoisomeric alcohols can often result. The recognition that multiple yeast reductases with conflicting stereoselectivity are the main source of these difficulties has inspired a search for methods to improve the outcome of whole cell bioreductions via genetic engineering techniques (Section 7.3). ${ }^{11,295,298,299,302} \mathrm{~A}$ number of alternative strategies aimed at improving stereoselectivity of ketone reductions by whole yeast cells has also been explored, usually by selectively diminishing the catalytic activities of reductases that yield unwanted products. Thus, substrate modification, ${ }^{303}$ changes in the carbon source or growing conditions, ${ }^{304}$ the use of inhibitors, ${ }^{305-307}$ addition of inorganic salts, ${ }^{308,309}$ thermal pre-treatment, ${ }^{310}$ and immobilisation of Baker's yeast ${ }^{311}$ have been employed to improve the enantioselectivities of Baker's yeast reductions.

\subsection{Baker's yeast reduction of sulfur containing compounds}

Ridley and co-workers were one of the first groups to attempt Baker's yeast reductions of sulfurfunctionalised acetone derivatives and reported that the reduction proceeded more efficiently for sulfoxides and sulfones than for the corresponding sulfides. ${ }^{312}$ Enzymatic enantioselective reductions of $\beta$-keto phenylsulfones has attracted considerable attention from synthetic chemists in the past few decades. The enantioenriched $\beta$-hydroxyl phenylsulfones are useful building blocks in natural product synthesis, as the keto group reductions proceed with very high stereoselectivity. ${ }^{313}$ Moreover, the phenylsulfonyl group allows for further functionalisation and can easily be removed without any racemisation of the chiral centre. ${ }^{314}$ Simple acyclic $\beta$-keto sulfones have been reduced using Baker's yeast. ${ }^{312,313,315,316}$ However, the enantioselectivity and efficiency of reduction decreased considerably once the alkyl chain was extended. ${ }^{313,317,318}$ Svatos et al. investigated the reduction of $\gamma$-methyl- $\beta$-ketosulfones by 20 different yeasts and achieved $99 \%$ e.e. in the case of Schizosaccharomyces pombe. ${ }^{319}$ Baker's yeast reduction of sulfur containing compounds has been reviewed in detail within this research group. ${ }^{306,307}$ One recent example of enzymatic reduction of $\beta$ ketosulfones by a whole cell system is the reduction of $\beta$-ketosulfone groups bearing bulky substituents by the fungus Culvaria lunata with an enantiomer excess of $97 \% .{ }^{320}$ Examples of Baker's yeast mediated resolutions of 2-keto sulfides, sulfoxide and sulfones are depicted in Figure 17 below. 


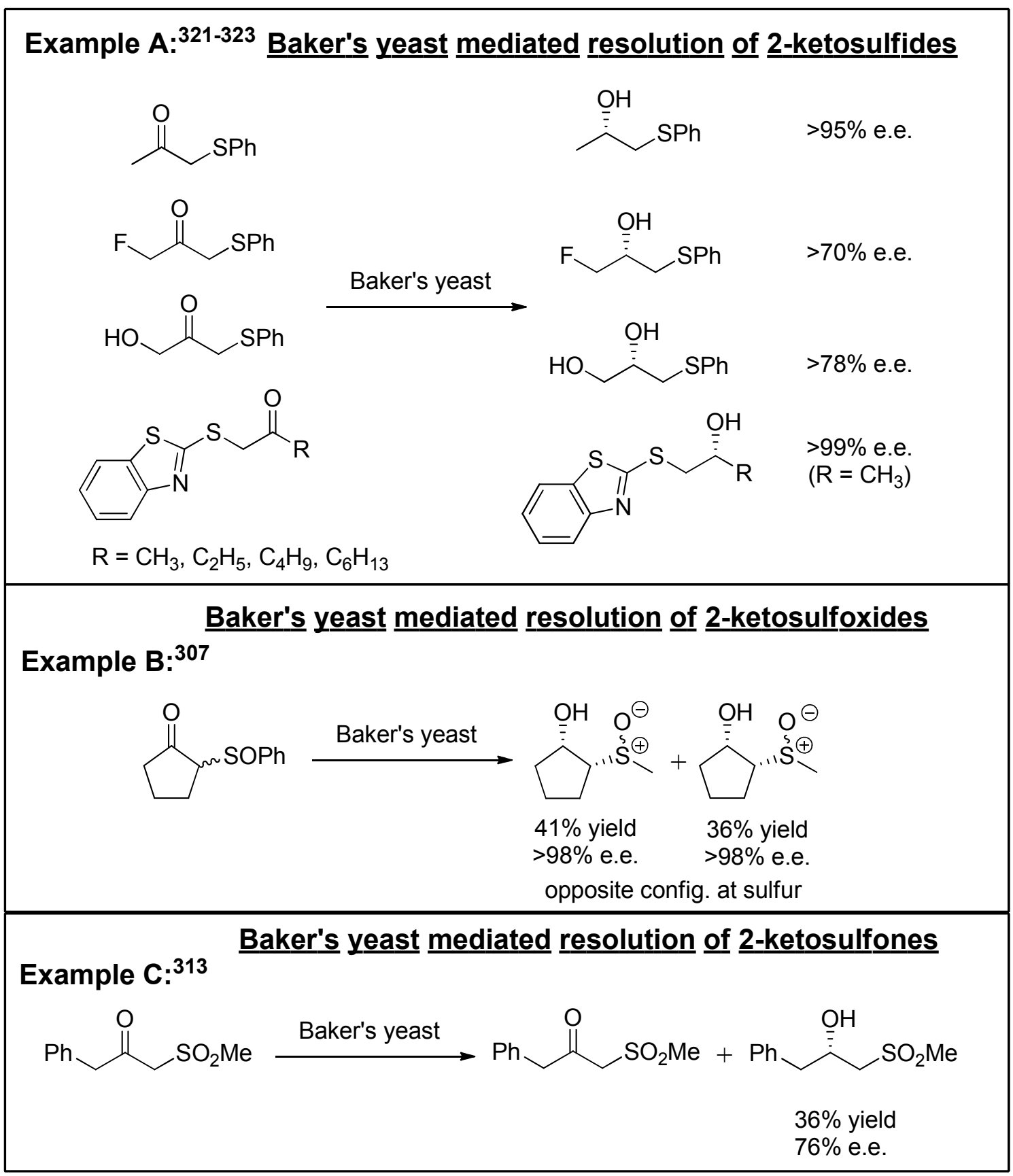

\section{Figure 17}

\subsection{Genetically engineered Baker's yeast}

Sequencing of the 12,057,500 chemical subunits contained in yeast's nuclear DNA was completed in 1996 following a combined initiative involving 92 laboratories worldwide. ${ }^{324-326}$ The identification of all 6,000 yeast genes arranged on 16 chromosomes paved the way for future investigations of individual gene functioning in Baker's yeast mediated reductions and, hence, the rational design of engineered strains to achieve improved stereoselectivities. Later work led to the 
division of yeast reductases into different families based on their length, consensus motifs, sequence identities and conserved residues. ${ }^{327}$

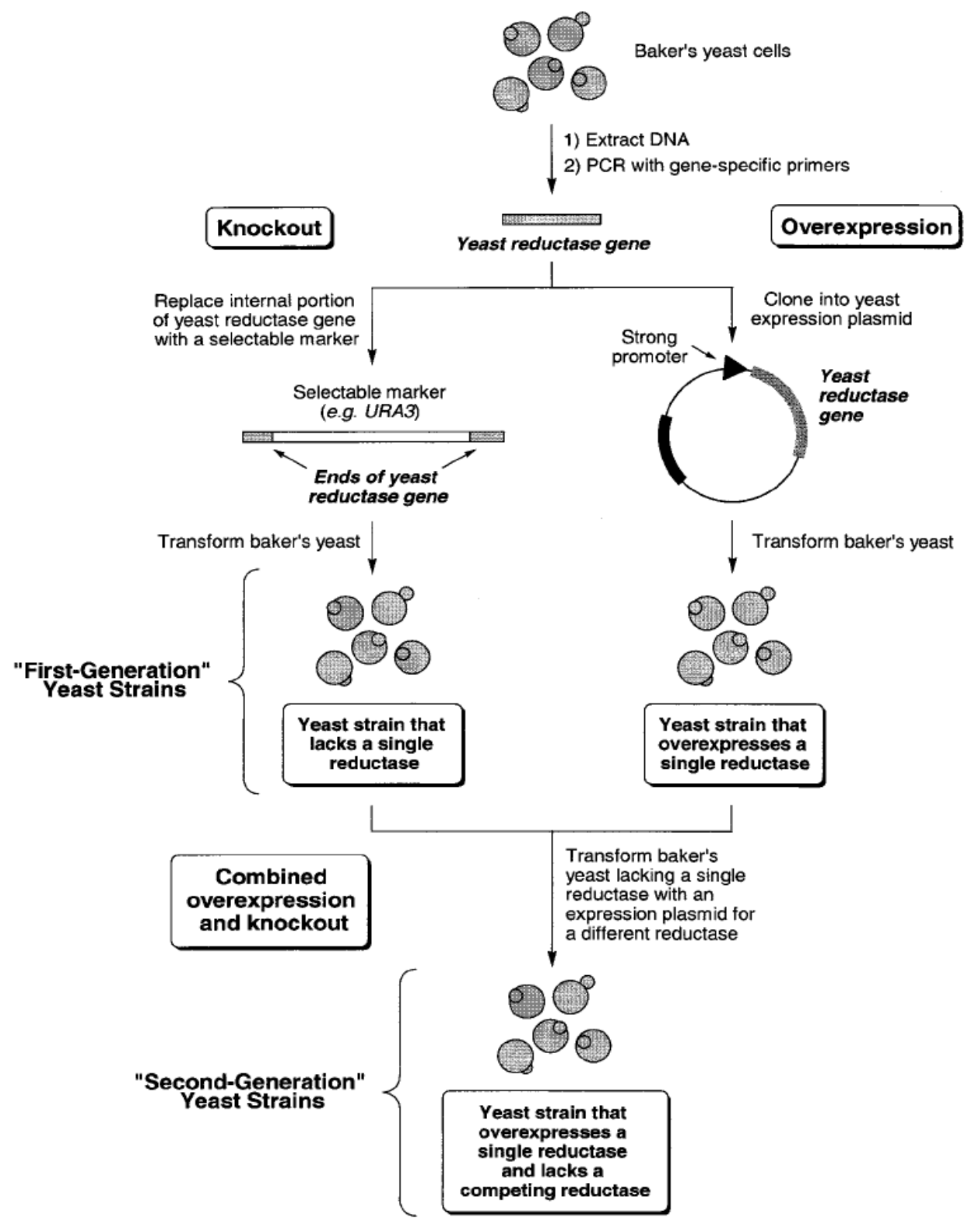

Figure 18. Genetic engineering strategies for Baker's yeast (reproduced from ref. 333).

Two main yeast protein superfamilies capable of oxidoreduction of endogenous and xenobiotic carbonyls have been identified; namely the aldo-keto reductase (AKR) and short-chain dehydrogenase/reductase (SDR) superfamilies, with the smaller dihydroflavanol reductase (DFR) family also being observed in certain cells. Numerous studies of these protein superfamilies have lead to the identification of genes encoding these various reductases and the observation of substrate specific trends for these individual genes. The task of identifying individual ketone reductases is currently underway. An alternative approach is gene knockout technology. This eliminates the 
catalytic activities of competing ketone reductases. A number of different strategies may be adopted in the genetic manipulation of Baker's yeast. Foremost amongst these has been the employment of gene overexpression and gene knockout techniques. (Figure 18). ${ }^{328}$ For both approaches, initial identification of the individual yeast genes encoding the desired reductases is required to allow the production of genetically altered Baker's yeast strains which produce the targeted product in high enantiomeric excess. Gene knockout technology offers an alternative approach to eliminating the catalytic activities of competing ketone reductases, provided that their identities are known. ${ }^{328}$

Sih et al. pioneered this work in order to improve the enantioselectivity of reduction of a $\beta$-keto ester; the fatty acid synthase deficient strain led to a dramatic increase in enantioselectivity and altered stereospecificity (Scheme 21). ${ }^{329}$

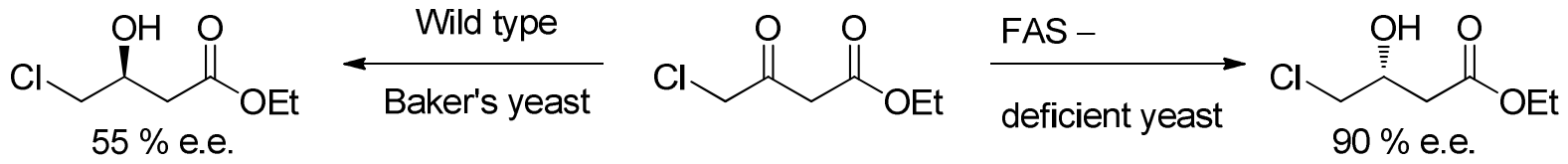

Scheme 21. Ketone reductions by wild type and fatty acid synthase deficient (FAS-) Baker's yeast.

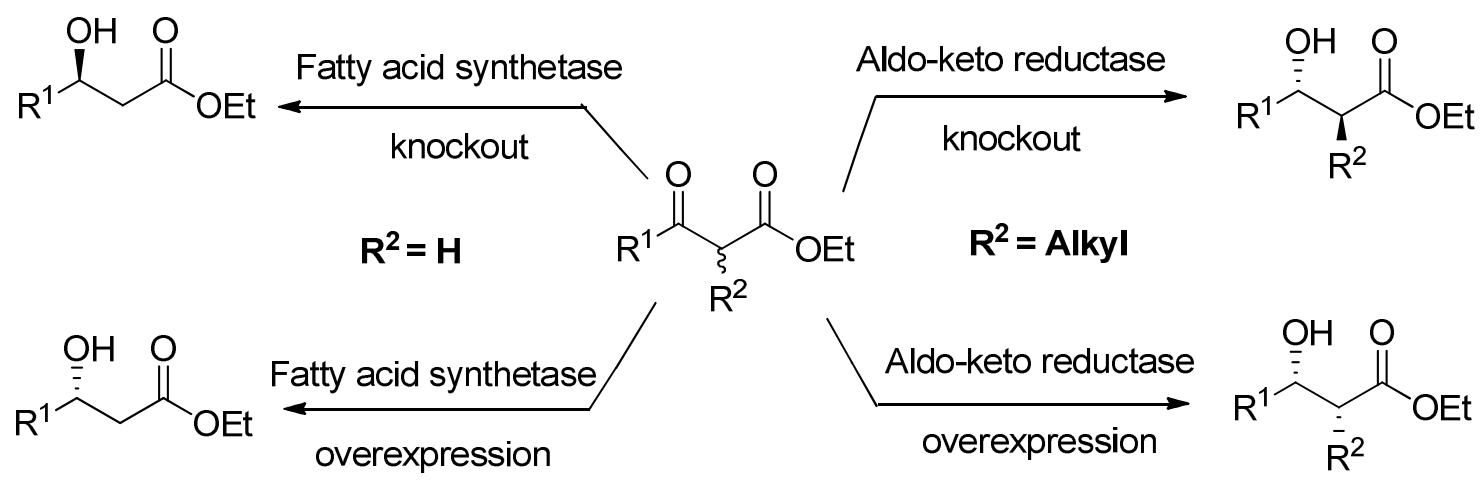

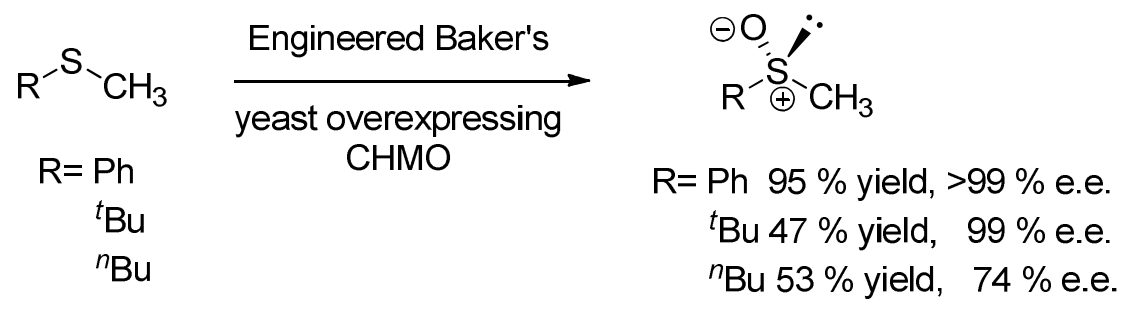

\section{Scheme 22}

Later, Stewart et al. created a strain of $S$. cerevisiae that overexpresses cyclohexanone monooxygenase (CHMO) so that the whole yeast cells could be used as the biocatalytic oxidant for a variety of ketones. ${ }^{330}$ The stereoselectivities of Baker's yeast catalysed reductions were significantly improved by Kayser et al. by employing recombinant DNA techniques, and rational design of the engineered strains. This genetic engineering approach requires the identification of the genes encoding each enzyme. The undesirable yeast reductases are subsequently disabled by gene 
knockout technology while overproducing those reductase enzymes with desirable stereoselectivities. The aforementioned methodology was employed to improve the selectivity of $\beta$ keto ester reductions (Scheme 22), the synthesis of novel optically pure $\beta$-lactams, and sulfur oxidations (Scheme 22). ${ }^{331-333}$

\section{Ketoreductases}

\subsection{Introduction}

Traditional methods of biocatalytic carbonyl reduction, as discussed above, have been achieved by employment of Baker's yeast as a whole cell catalytic system due to its inexpensive and convenient nature. However, as mentioned in Section 7, multiple products may be achieved due to the presence of multiple oxidoreductases contained in Baker's yeast cells. However, ketoreductases, an abundant group of oxidoreductase, are present in various bacteria, yeast, and fungi, ${ }^{335,336}$ and commonly participate in many biological processes in all living organisms. ${ }^{337}$ Enzymatic reductions using a purified reductase usually possess high stereoselectivity and eliminate problems with compound toxicity associated with viable cells. ${ }^{338}$ When Stewart et al. examined the genome of Baker's yeast the results indicated the potential for 50 ketoreductases of which 19 were over expressed, isolated, and studied. ${ }^{339}$ The novel isolated ketoreductases reduced a wide range of ketones and produced both enantiomers of most products depending on the ketoreductase employed (Figure 19). ${ }^{339}$
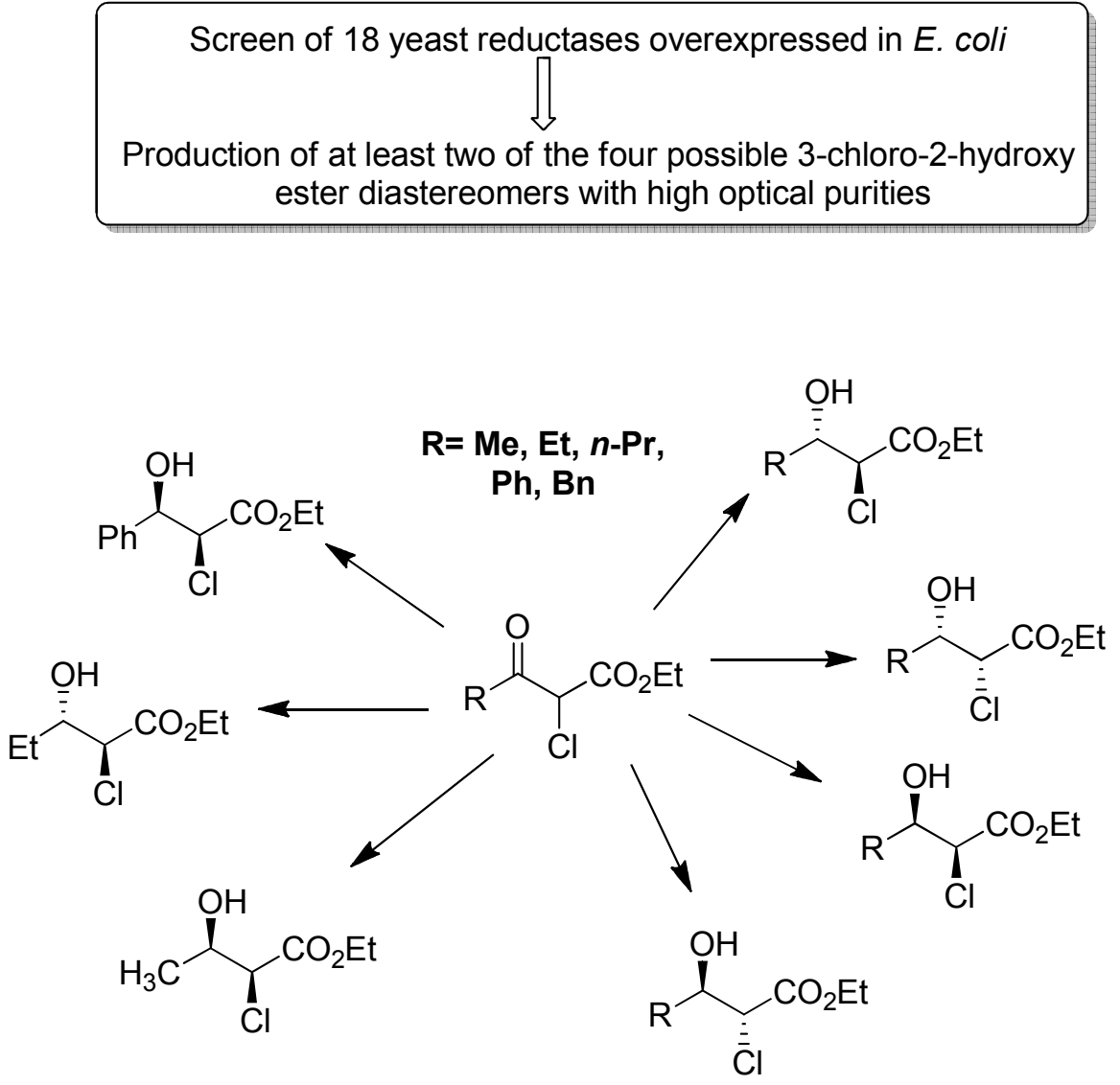

Figure 19 
Extending this technology to the entire genetic database allowed the commercialisation of larger collections of ketoreductase enzymes and enabled the rapid production of large quantities of enzyme on demand. ${ }^{339}$ A further advantage of ketoreductase technology is the rapidity by which these screens can be performed. ${ }^{339}$ An overview of the latest achievements in the field of asymmetric ketoreductase-mediated carbonyl reductions can be found in recent reviews. ${ }^{29,66,327,340-}$ 342

\subsection{Cofactor recycling systems}

All ketoreductase biocatalysis require a hydride source in either the form of nicotinamide adenine dinucleotide $(\mathrm{NADH})$ or nicotinamide adenine dinucleotide phosphate (NADPH); due to the high associated costs of these cofactors it is not practically feasible to use them stoichiometrically. Therefore, cofactor recycling systems have been developed in order to recycle the hydride source by oxidising the $\mathrm{NAD}(\mathrm{P})^{+}$back to $\mathrm{NAD}(\mathrm{P}) \mathrm{H}$ and drive the reaction to completion. Some commonly used recycling systems are depicted in Figure $20 .^{29}$

\section{Enzyme mediated cofactor recycling}

$\underline{\text { FDH }}$

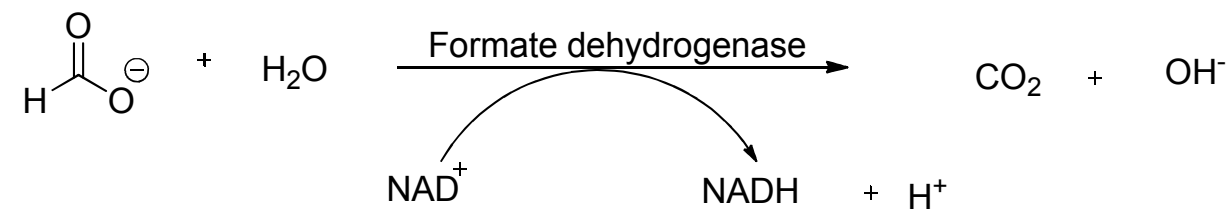

\section{$\underline{\text { GDH }}$}

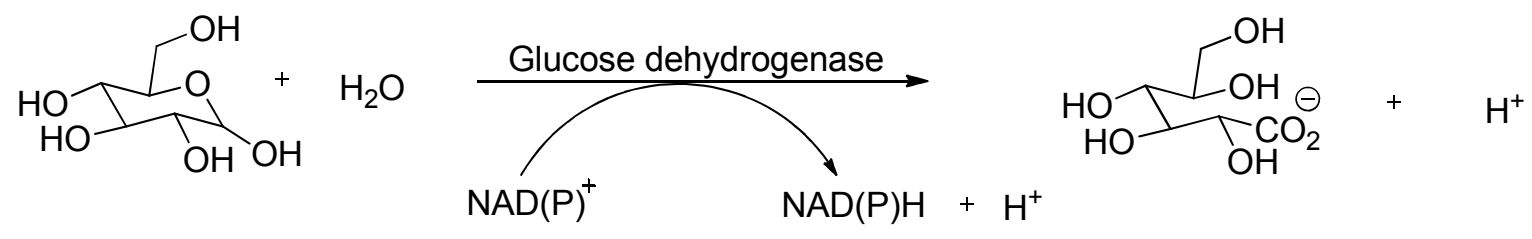

$\underline{\text { PDH }}$

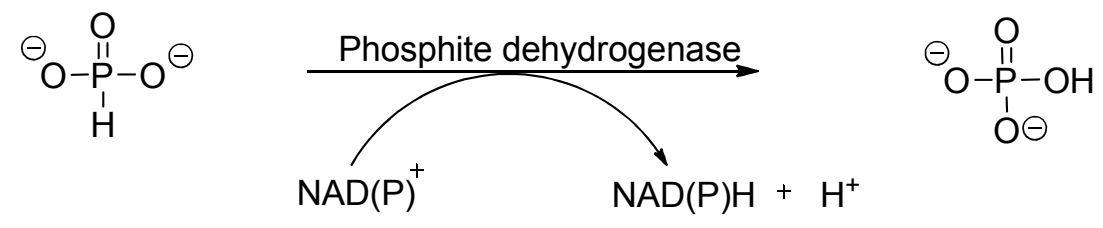

\section{Substrate coupled cofactor recycling}

IPA

Figure 20<smiles>CC(C)O</smiles><smiles>CC(C)=O</smiles>

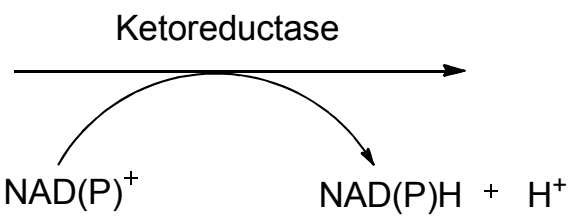


Glucose dehydrogenase (GDH), formate dehydrogenase (FDH), phosphite dehydrogenase (PDH) are second enzymes added to the process in a coupled enzyme approach. ${ }^{336}$ GDH is commonly the preferred recycling system due to its high stability and activity; furthermore, it recycles both $\mathrm{NAD}^{+}$and $\mathrm{NADP}^{+}$. However, due to the formation of gluconic acid (Figure 20), in order to prevent enzyme denaturation, neutralisation of the reaction media with the addition of base is required. In addition, by monitoring the amount of base added, facile determination of reaction completion is feasible.

Researchers at Merck developed an efficient asymmetric enzymatic reduction of 4,4dimethoxytetrahydro- $2 H$-pyranone 19 which provides the enantiopure $(R)$-hydroxyketal 20 an important chiral precursor for a pharmaceutical intermediate, in high yield including an in situ NADPH-cofactor regeneration system using glucose dehydrogenase. The optimised two-enzyme process was demonstrated successfully at $80 \mathrm{~kg}$ pilot-plant scale (Scheme 23). ${ }^{343}$

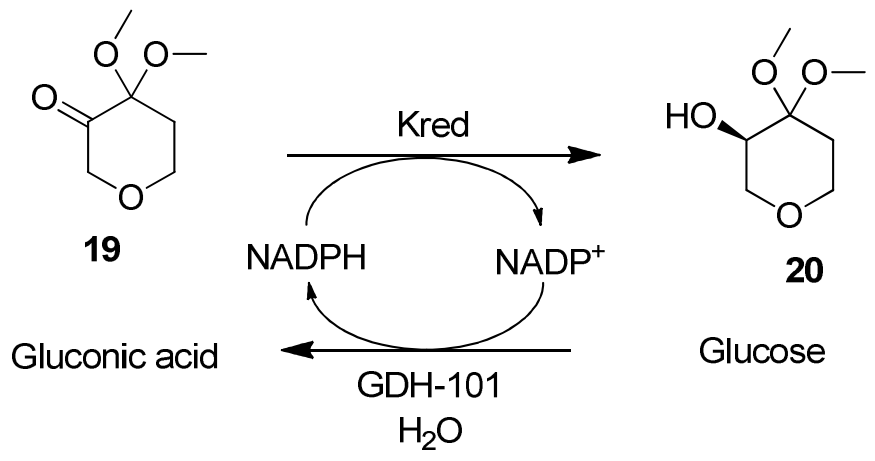

\section{Scheme 23}

Formate dehydrogenase is typically less stable than GDH and only used for the regeneration of $\mathrm{NAD}^{+}$. FDH also requires $\mathrm{pH}$ adjustment with acid, which is attractive for base labile compounds. FDH has been shown by Moore et al. to produce (S)-3,5-bis(trifluoromethyl)phenylethanol 22, a pharmaceutically important alcohol intermediate for the synthesis of NK-1 receptor antagonists, via asymmetric enzymatic ketone reduction. The isolated enzyme alcohol dehydrogenase from Rhodococcus erythropolis reduced the poorly water soluble substrate $\mathbf{2 1}$ with excellent enantiomeric excess $(>99.9 \%)$ and conversion $(>98 \%)$ on a lab scale (Scheme 24$)$. However, when this transformation was scaled to pilot plant scale, glucose dehydrogenase was employed as the cofactor regeneration system. GDH exhibited increased stability to reaction conditions, and use of this enzyme also allowed access to both enantiomers of 3,5-bis(trifluoromethyl)phenylethanol 22 in excellent enantiopurity by simple switching of a ketoreductase, which was not possible with formate dehydrogenase. ${ }^{344}$ Phosphite dehydrogenase is a novel technology in cofactor recycling; it simply converts the reaction buffer from phosphite to phosphate with no significant change in $\mathrm{pH}$ which is attractive for $\mathrm{pH}$ sensitive compounds. ${ }^{345,346}$ 
<smiles>CC(=O)c1cc(C(F)(F)F)cc(C(F)(F)F)c1</smiles>
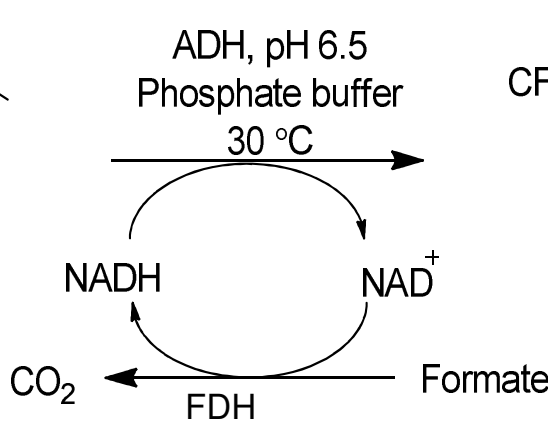<smiles>C[C@H](O)c1cc(C(F)(F)F)cc(C(F)(F)F)c1</smiles>

\section{Scheme 24}

The final example of cofactor recycling discussed here is a substrate coupled approach, this method takes advantage of the fact that the ketoreductase not only reduces the ketone of interest, but will also oxidise an alcohol such as isopropanol.

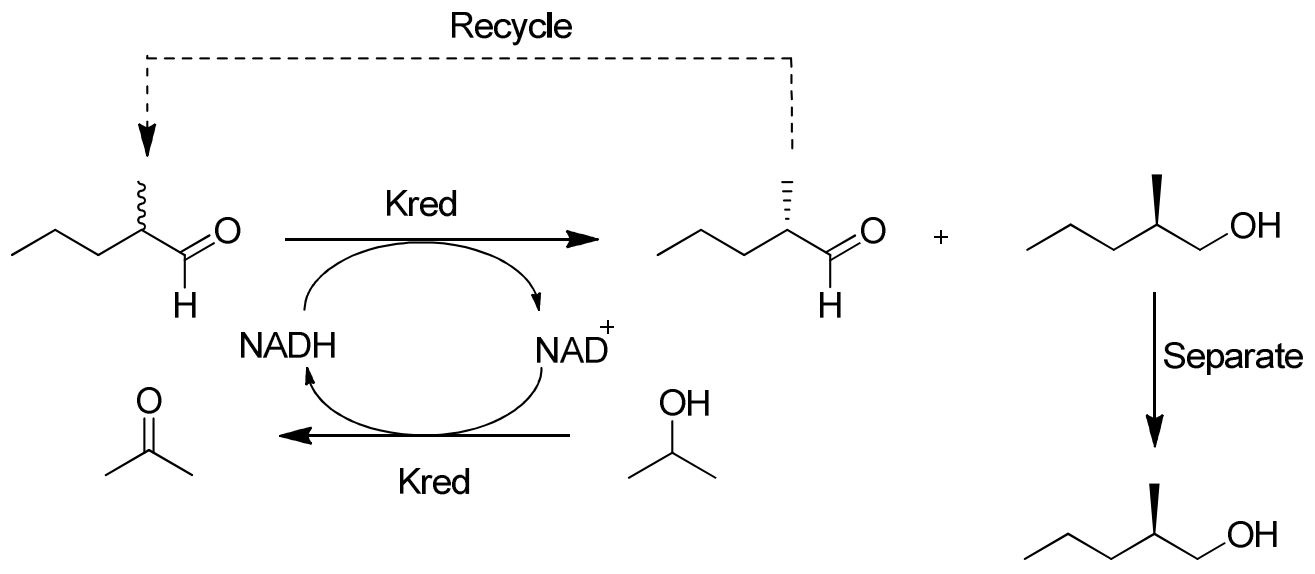

\section{Scheme 25}

This system requires a large molar excess of alcohol relative to the ketone. A principal advantage of this method is that no $\mathrm{pH}$ adjustment is required and the acetone byproduct is easy to remove. Savile et al. ${ }^{347}$ developed an efficient dynamic kinetic resolution protocol employing isopropanol as cofactor for the generation of $(R)$-2-methylpentanol (Scheme 25). The ketoreductase enzyme is the sole enzyme employed in the catalytic cycle. 


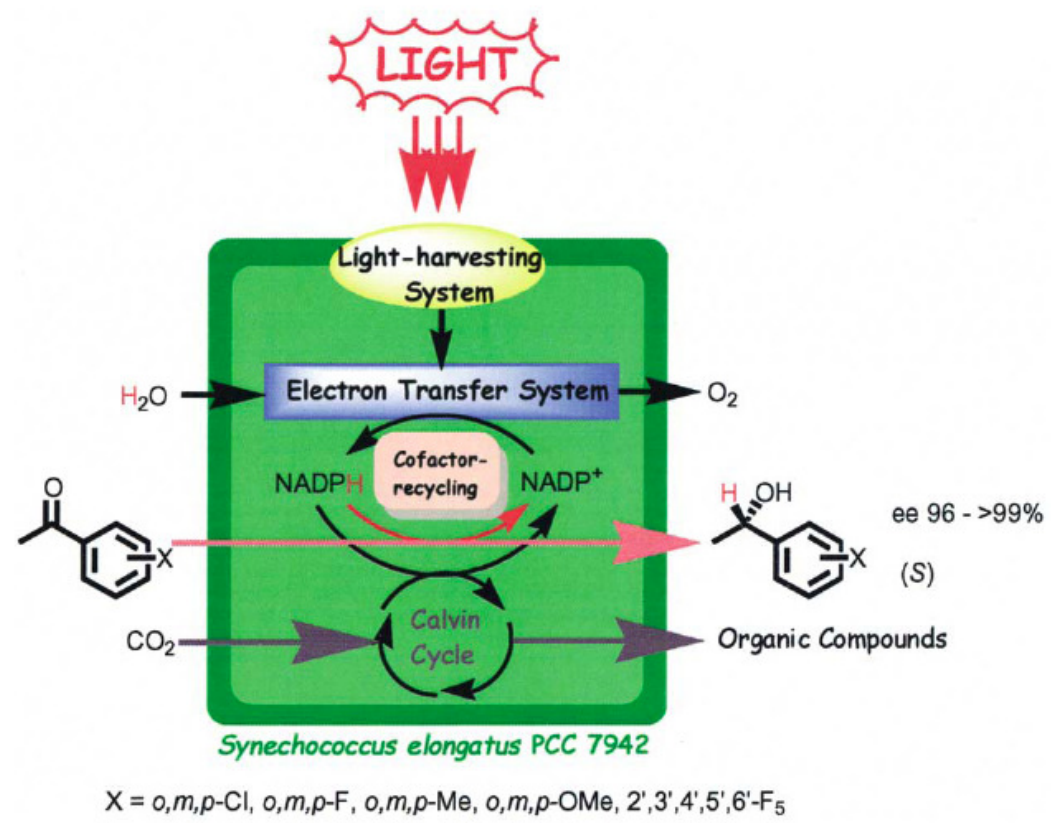

Scheme 26. Reproduced from reference 343.

This makes process economics quite favourable, since a second enzyme is not required to regenerate the cofactor. A purification and isolation method for separating the product from the unreacted substrate was also developed. The process has been successfully scaled to produce $100 \mathrm{~kg}$ of material suitable for use in the production of an API. ${ }^{347}$

Other, more environmentally benign methods to regenerate $\mathrm{NAD}(\mathrm{P}) \mathrm{H}$ include photochemical methods which utilise light energy, by the use of a cyanobacterium, a photosynthetic biocatalyst. ${ }^{348-}$ ${ }^{351}$ Using biocatalysts, the reduction of acetophenone derivatives was investigated and was found to occur more effectively under illumination than in the dark. The light energy harvested by the cyanobacterium is converted into chemical energy in the form of NADPH through an electron transfer system, and consequently, the chemical energy (NADPH) is used to reduce the substrate to the chiral alcohol (96 - >99\% e.e), (Scheme 26). ${ }^{348-352}$ Electrochemical methods have also been reported. $^{28,350}$

\subsection{Examples of ketoreductase-mediated enantioenriched alcohol synthesis}

Highly enantioselective ketoreductase-mediated resolutions have been performed at a lab scale ${ }^{66,68-}$ $71,340,343,347$ by a number of researchers and these have been reviewed in detail. ${ }^{29,340,353}$ The availability of commercial ketoreductase kits has led to widespread screening of these isolated enzymes by chemists (Figure 19 and 21). ${ }^{354}$ 


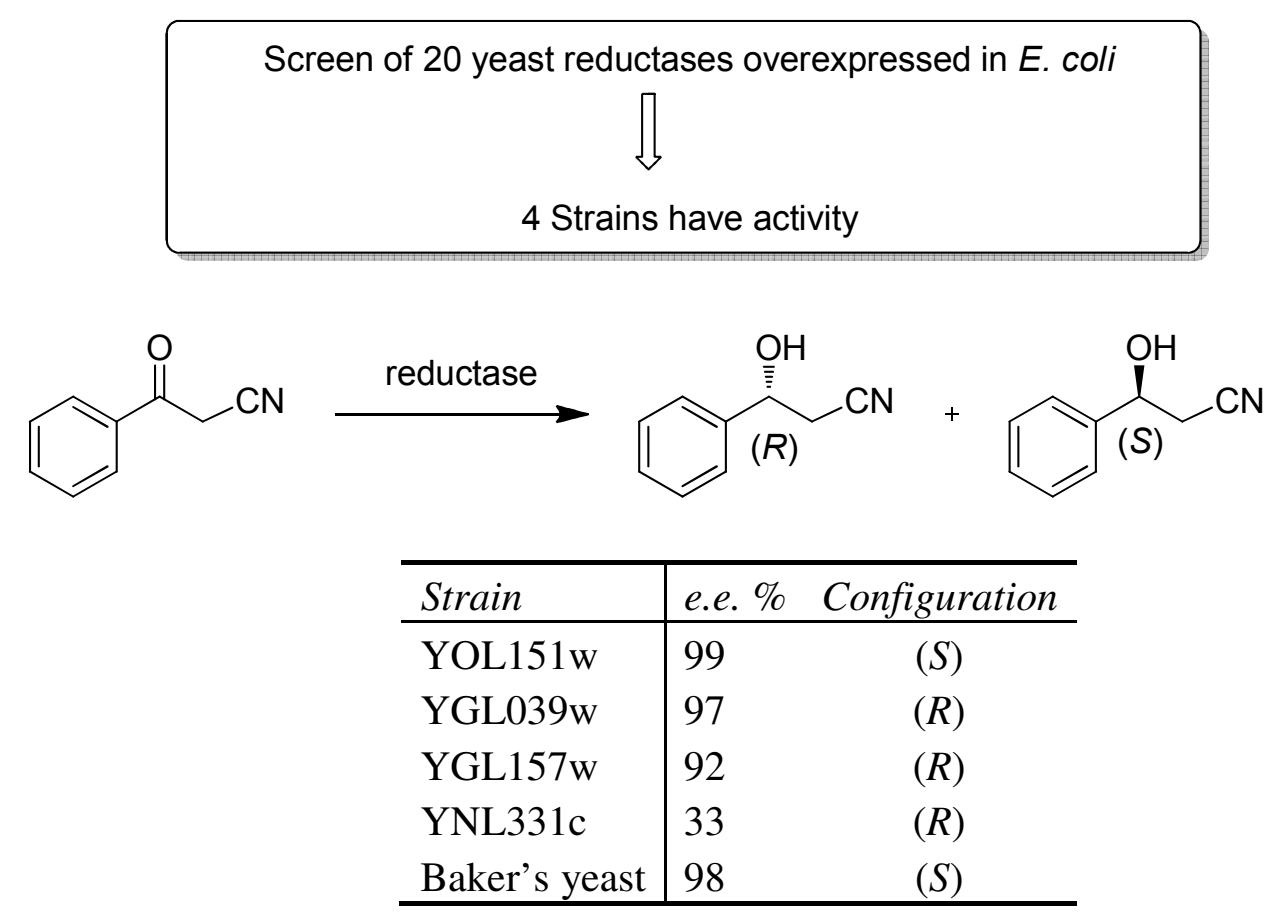

\section{Figure 21}

Furthermore, over the past 2-3 years ketoreductase technology has been routinely employed for the commercial synthesis of chiral alcohols, and are now the preferred catalysts for the synthesis of chiral alcohols via ketone reduction. ${ }^{340}$ Examples of enantioenriched alcohols generated by ketoreductase-mediated reduction on an industrial scale and their application are illustrated in Figure 22. 


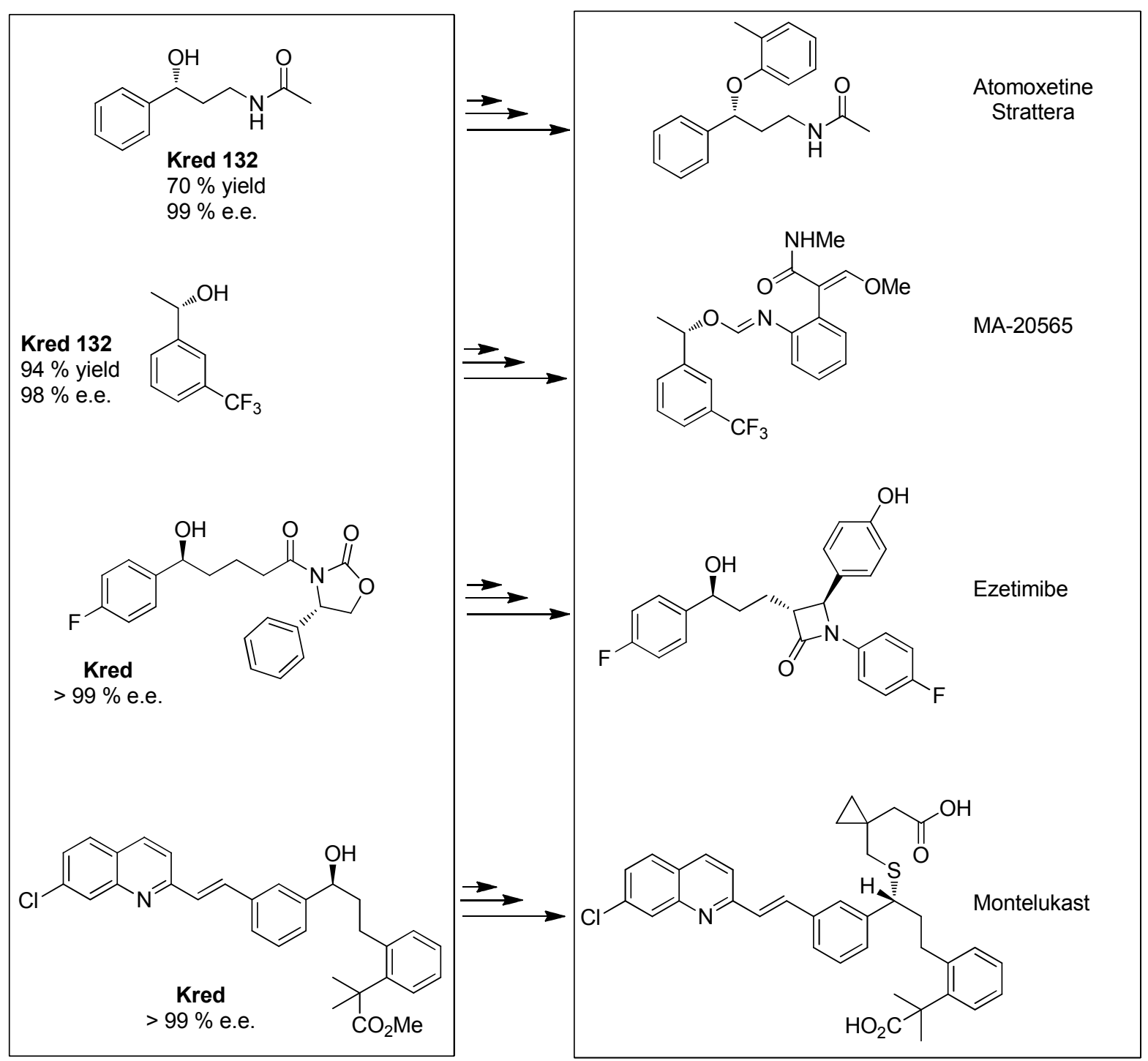

\section{Figure 22}

Two kinds of novel enoate reductases were isolated from Baker's yeast by Kawai et al. which led to nitroalkane enantiopurities of $>98 \%$ e.e (Scheme 27). ${ }^{334}$ Deuterium labelling studies were carried out and it was concluded that the yeast-mediated reduction of the nitroalkene proceeds in two stages: a reversible non stereoselective protonation of the $\alpha$-carbon followed by a stereoselective addition of a hydride from a enzyme at the $\beta$-position. ${ }^{334}$

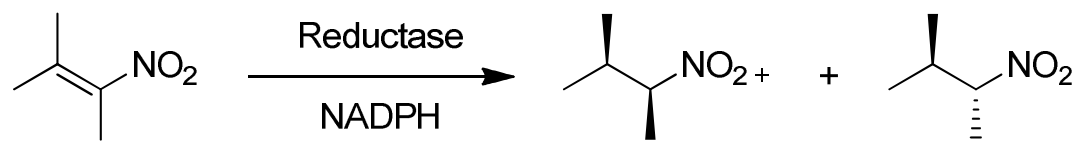

\section{Scheme 27}




\section{References}

1. Thayer, A. M. Chemical \& Engineering News 2006, 84, 10-14.

2. Carey, J. S.; Laffan, D.; Thomson, C.; Williams, M. T. Org. Biomol. Chem. 2006, 4, 23372347.

3. http://www.fda.gov

4. Ojima, I. Catalytic Asymmetric Synthesis; 3 ed.; John Wiley \& Sons: New Jersey, 2010.

5. Shao, Z. H.; Zhang, H. B. Chem. Soc. Rev. 2009, 38, 2745-2755.

6. Amouri, H.; Gruselle, M.; Woolins, D.; Atwood, D. A. Chirality in transition metalchemistry; John Wiley \& Sons: West Sussex, 2008.

7. MacMillan, D. W. C. Nature 2008, 455, 304-308.

8. List, B. Asymmetric organocatalysis; Springer: Heidelberg Dordrecht London New York, 2010.

9. Berkessel, A.; Gröger, H. Asymmetric Organocatalysis-From Biomimetic Concepts to Applications in Asymmetric Synthesis; Wiley-VCH Verlag GmbH \& Co. KGaA: Weinheim, 2005.

10. Pellissier, H. Recent Developments in Asymmetric Organocatalysis; The Royal Society of Chemistry: Cambridge, 2010.

11. Bommarius, A. S.; Riebel, B. R. Biocatalysis; Wiley-VCH Verlag GmbH \& Co. KGaA: Darmstadt, 2004; Milner, S.E.; Brossat, M.; Moody, T.S.; Elcoate, C.J.;

Lawrence, S.E.; Maguire, A.R. Tetrahedron: Asymmetry, 2010 , 21, 1011-1016; Deasy, R.E.; Brossat, M.; Moody, T.S.; Maguire, A.R. Tetrahedron: Asymmetry, 2011, 22, 47-61.

12. Schauer, F.; Borriss, R. Biocatalysis and biotransformation. Advances in Fungal Biotechnology for Industry, Agriculture, and Medicine; Kluwer Academic/Plenum Publishers: New York, 2004.

13. Tao, J.; Lin, G.; Liese, A. Biocatalysis for the Pharmaceutical Industry: Discovery, Development and Manufacturing; John Wiley \& Sons: Singapore, 2009.

14. Carballeira, J. D.; Fernandez-Lucas, J.; Quezada, M. A.; Hernaiz, M. J.; Alcantara, A. R.; Sime, Y.; Sinisterra, J. V. In Encyclopedia of Microbiology; Edited by Moselio, Schaechter, Ed.; Academic Press: Oxford, 2009; pg 212-251.

15. Schmid, A.; Dordick, J. S.; Hauer, B.; Kiener, A.; Wubbolts, M.; Witholt, B. Nature 2001, 409, 258-268.

16. Jacobsen, E. N.; Pfaltz, A.; Yamamoto, H. Comprehensive asymmetric catalysis; Springer Berlin Heidelberg: New York, 2011.

17. Christmann, M.; Braese, S. Asymmetric Synthesis-The Essentials; 2 ed.; Wiley-VCH, Verlag GmBH \& Co: Weinheim, Germay, 2008.

18. Bommarius, A. S.; Riebel, B. R. Biocatalysis; Wiley-VCH Verlag GmbH \& Co. KGaA: 2004, $\operatorname{pg} 2$.

19. Tipton, K.; Boyce, S. Bioinformatics 2000, 16, 34-40.

20. Straathof, A. J. J.; Panke, S.; Schmid, A. Curr. Opin. Biotechnol. 2002, 13, 548-556.

21. Marrs, B.; Delagrave, S.; Murphy, D. Curr.Opin. Microbiol. 1999, 2, 241-245. 
22. Chaput, J. C.; Woodbury, N. W.; Stearns, L. A.; Williams, B. A. R. Expert Opin. Biol. Ther. 2008, 8, 1087-1098.

23. Vaghjiani, J. D.; Lee, T. S.; Lye, G. J.; Turner, M. K. Biocatal. Biotransform. 2000, 18, 151175.

24. Villeneuve, P.; Muderhwa, J. M.; Graille, J.; Haas, M. J. J. Mol. Catal. B: Enzym. 2000, 9, 113-148.

25. Pollard, D. J.; Woodley, J. M. Trends Biotechnol. 2007, 25, 66-73.

26. http://www.chem.qmul.ac.uk/iubmb/enzyme/

27. Published in Enzyme Nomenclature 1992 [Academic Press, San Diego, California, ISBN 0-12227164-5 (hardback), 0-12-227165-3 (paperback)] with Supplement 1 (1993), Supplement 2 (1994), Supplement 3 (1995), Supplement 4 (1997) and Supplement 5 (in Eur. J. Biochem. 1994, 223, 1-5; Eur. J. Biochem. 1995, 232, 1-6; Eur. J. Biochem. 1996, 237, 1-5; Eur. J. Biochem. 1997, 250; 1-6, and Eur. J. Biochem. 1999, 264, 610-650; respectively) [Copyright IUBMB]. 2011.

28. Hollmann, F.; Arends, I. W. C. E.; Buehler, K. Chemcatchem 2010, 2, 762-782.

29. Moore, J. C.; Pollard, D. J.; Kosjek, B.; Devine, P. N. Acc. Chem. Res. 2007, 40, 1412-1419.

30. Pollard, D. J.; Woodley, J. M. Trends Biotechnol. 2007, 25, 66-73.

31. Rozzell, J. D. Chim. Oggi-Chem. Today 1999, 17, 42-47.

32. Rozzell, J. D. Bioorg. Med. Chem. 1999, 7, 2253-2261.

33. Lu, D.; Wei, P.; Zhou, H.; Jia, H.; Ouyang, P. Huagong Jinzhan 2004, 23, 585-589.

34. Wang, M. X. Top. Catal. 2005, 35, 117-130.

35. Panke, S.; Wubbolts, M. Curr.Opin. Chem. Biol. 2005, 9, 188-194.

36. Faber, K.; Kroutil, W. Curr. Opin. Chem. Biol. 2005, 9, 181-187.

37. Zhang, L.; Cheng, K.; Zhu, P. Yaoxue Xuebao 2004, 39, 153-157.

38. http://www.epa.gov/greenchemistry/pubs/epa_gc.html, 2010.

39. Anastas, P.; Eghbali, N. Chem. Soc. Rev. 2010, 39, 301-312.

40. Tanaka, A.; Tosa, T.; Kobayashi, A. Industrial Application of Immobilized Biocatalysts (Biotechnology and Bioprocessing); Marcel Dekker Inc: New York, 1993.

41. Liese, A.; Seebach, D.; Wandrey, C. Industrial Biotransformations; Wiley-VCH: Weinheim, 2006.

42. Nelson, D. L. Lehninger Principles of Biochemistry; 3 ed.; Worth: New York, 2000.

43. Lapanje, S. Physicochemical Aspects of Protein Denaturation; John Wiley \& Sons: New York, 1978.

44. Griebenow, K.; Klibanov, A. M. J. Am. Chem. Soc. 1996, 118, 11695-11700.

45. Klibanov, A. M. Nature 2001, 409, 241-246.

46. Hazarika, S.; Goswami, P.; Dutta, N. N.; Hazarika, A. K. Chem. Eng. J. 2002, 85, 61-68.

47. Sztajer, H.; Lunsdorf, H.; Erdmann, H.; Menge, U.; Schmid, R. Biochim. Biophys. Acta 1992, 1124, 253-261.

48. Zaks, A.; Klibanov, A. M. J. Biol. Chem. 1988, 263, 3194-3201.

49. Azevedo, A. M.; Prazeres, D. M. F.; Cabral, J. M. S.; Fonseca, L. P. J. Mol. Catal. B: Enzym. 2001, 15, 147-153. 
50. Khmelnitsky, Y. L.; Rich, J. O. Curr. Opin. Chem. Biol. 1999, 3, 47-53.

51. Mattiasson, B.; Holst, O. Extractive Bioconversions; Marcel Dekker Inc: New York, Basel, Hong Kong, 1991.

52. Vermue, M. H.; Tramper, J. Pure Appl. Chem. 1995, 67, 345-373.

53. Pencreac'h, G.; Baratti, J. C. Enzyme Microb. Technol. 2001, 28, 473-479.

54. Reslow, M.; Adlercreutz, P.; Mattiasson, B. Appl. Microbiol. Biotechnol. 1987, 26, 1-8.

55. Zaks, A.; Klibanov, A. M. Science 1984, 224, 1249-1251.

56. Gupta, M. N.; Roy, I. Eur. J. Biochem. 2004, 271, 2575-2583.

57. Krishna, S. H. Biotechnol. Adv. 2002, 20, 239-267.

58. Morgan, B.; Dodds, D. R.; Zaks, A.; Andrews, D. R.; Klesse, R. J. Org. Chem. 1997, 62, 7736-7743.

59. Patel, R. N.; Banerjee, A.; Szarka, L. J. Tetrahedron: Asymmetry 1997, 8, 1767-1771.

60. Patel, R. N.; Mcnamee, C. M.; Szarka, L. J. Appl. Microbiol. Biotechnol. 1992, 38, 56-60.

61. Bruggink, A. Chimia 1996, 50, 431-432.

62. Kirchner, G.; Scollar, M. P.; Klibanov, A. M. J. Am. Chem. Soc. 1985, 107, 7072-7076.

63. Carrea, G.; Riva, S. Angew. Chem. Int. Ed. 2000, 39, 2226-2254.

64. Michels, P. C.; Dordick, J. S.; Clark, D. S. J. Am. Chem. Soc. 1997, 119, 9331-9335.

65. Marbrouk, P. A. J. Am. Chem. Soc. 1995, 117, 2141-2146.

66. Sorgedrager, M. J.; van Rantwijk, F.; Huisman, G. W.; Sheldon, R. A. Adv. Synth. Catal. 2008, 350, 2322-2328.

67. Tewari, Y. B.; Schantz, M. M.; Phinney, K. W.; Rozzell, J. D. J. Chem. Thermodyn. 2005, 37, 89-96.

68. Tewari, Y. B.; Phinney, K. W.; Liebman, J. F. J. Chem. Thermodyn. 2006, 38, 388-395.

69. Tewari, Y. B.; Liebman, J. F.; Rozzell, J. D.; Vanderah, D. J.; Schantz, M. M. J. Chem. Thermodyn. 2007, 39, 1090-1097.

70. Tewari, Y. B.; Kishore, N.; Rozzell, J. D.; Vanderah, D. J.; Schantz, M. M. J. Chem. Thermodyn. 2006, 38, 1165-1171.

71. Tewari, Y. B.; Vanderah, D. J.; Schantz, M. M.; Goldberg, R. N.; Rozzell, J. D.; Liebman, J. F.; Hui, R. W. M.; Nissenbaum, Y.; Parniani, A. R. J. Chem. Thermodyn. 2008, 40, 661-670.

72. Jessop, P. G.; Letiner, W. E. Chemical Synthesis using Supercritical Fluids; Wiley-VCH: Weinheim, 1999.

73. Leitner, W. Nature 2000, 405, 129-130.

74. DeSimone, J. M. Science 2002, 297, 799-803.

75. Leitner, W. Acc. Chem. Res. 2002, 35, 746-756.

76. Beckman, E. J. J. Supercrit. Fluids 2004, 28, 121-191.

77. Mesiano, A. J.; Beckman, E. J.; Russell, A. J. Biotechnol. Progr. 2000, 16, 64-68.

78. Garcia, S.; Lourenco, N. M. T.; Lousa, D.; Sequeira, A. F.; Mimoso, P.; Cabral, J. M. S.; Afonso, C. A. M.; Barreiros, S. Green Chem. 2004, 6, 466-470.

79. Hakoda, M.; Shiragami, N.; Enomoto, A.; Nakamura, K. Bioprocess Biosyst. Eng. 2003, 25, 243-247.

80. Randolph, T. W.; Blanch, H. W.; Prausnitz, J. M.; Wilke, C. R. Biotechnol. Lett. 1985, 7, 325- 
328.

81. Cantone, S.; Hanefeld, U.; Basso, A. Green Chem. 2007, 9, 954-971.

82. Hobbs, H. R.; Thomas, N. R. Chem. Rev. 2007, 107, 2786-2820.

83. Mesiano, A. J.; Beckman, E. J.; Russell, A. J. Chem. Rev. 1999, 99, 623-633.

84. Knez, E. J. Supercrit. Fluids 2009, 47, 357-372.

85. Tawaki, S.; Klibanov, A. M. J. Am. Chem. Soc. 1992, 114, 1882-1884.

86. Klibanov, A. M. Abstr. Pap.-Am. Chem. Soc. 1993, 206, 151-156.

87. Dordick, J. S. Biotechnol. Progr. 1992, 8, 259-267.

88. Vanerp, S. H. M.; Kamenskaya, E. O.; Khmelnitsky, Y. L. Eur. J. Biochem. 1991, 202, 379384.

89. Adams, K. A. H.; Chung, S. H.; Klibanov, A. M. J. Am. Chem. Soc. 1990, 112, 9418-9419.

90. Duan, G.; Chen, J. Y. Biotechnol. Lett. 1994, 16, 1065-1068.

91. Kitaguchi, H. J. Synth. Org. Chem. Jpn. 1995, 53, 381-391.

92. Rezaei, K.; Temelli, F.; Jenab, E. Biotechnol. Adv. 2007, 25, 272-280.

93. Matsuda, T.; Kanamaru, R.; Watanabe, K.; Harada, T.; Nakamura, K. Tetrahedron Lett. 2001, 42, 8319-8321.

94. Matsuda, T.; Kanamaru, R.; Watanabe, K.; Kamitanaka, T.; Harada, T.; Nakamura, K. Tetrahedron: Asymmetry 2003, 14, 2087-2091.

95. Palocci, C.; Falconi, M.; Chronopoulou, L.; Cernia, E. J. Supercrit. Fluids 2008, 45, 88-93.

96. Olsen, T.; Kerton, F.; Marriott, R.; Grogan, G. Enzyme Microb. Technol. 2006, 39, 621-625.

97. Vermue, M. H.; Tramper, J.; Dejong, J. P. J.; Oostrom, W. H. M. Enzyme Microb. Technol. 1992, 14, 649-655.

98. Varma, M. N.; Madras, G. Ind. Eng. Chem. Res. 2007, 46, 1-6.

99. Liu, K. J.; Cheng, H. M.; Chang, R. C.; Shaw, J. F. J. Am. Oil Chem. Soc. 1997, 74, 14771482 .

100. Habulin, M.; Knez, Z. J. Chem. Technol. Biotechnol. 2001, 76, 1260-1266.

101. Mase, N.; Sako, T.; Horikawa, Y.; Takabe, K. Tetrahedron Lett. 2003, 44, 5175-5178.

102. Kamat, S.; Critchley, G.; Beckman, E. J.; Russell, A. J. Biotechnol. Bioeng. 1995, 46, 610620.

103. Albrycht, M.; Kielbasinski, P.; Drabowicz, J.; Mikolajczyk, M.; Matsuda, T.; Harada, T.; Nakamura, K. Tetrahedron: Asymmetry 2005, 16, 2015-2018.

104. Kamat, S. V.; Beckman, E. J.; Russell, A. J. Crit. Rev. Biotechnol.1995, 15, 41-71.

105. Johnston, K. P.; Harrison, K. L.; Clarke, M. J.; Howdle, S. M.; Heitz, M. P.; Bright, F. V.; Carlier, C.; Randolph, T. W. Science 1996, 271, 624-626.

106. Stamatis, H.; Xenakis, A. J. Mol. Catal. B: Enzym. 1999, 6, 399-406.

107. Blattner, C.; Zoumpanioti, M.; Kroner, J.; Schmeer, G.; Xenakis, A.; Kunz, W. J. Supercrit. Fluids 2006, 36, 182-193.

108. Zoumpanioti, M.; Stamatis, H.; Xenakis, A. Biotechnol. Adv. 2010, 28, 395-406.

109. Moniruzzaman, M.; Nakashima, K.; Kamiya, N.; Goto, M. Biochem. Eng. J. 2010, 48, 295314.

110. Muginova, S. V.; Galimova, A. Z.; Polyakov, A. E.; Shekhovtsova, T. N. J. Anal. Chem. 
2010, 65, 331-351.

111. Zhao, H. J. Chem. Technol. Biotechnol. 2010, 85, 891-907.

112. Yu, H. L.; Ou, L.; Xu, J. H. Curr. Org. Chem. 2010, 14, 1424-1432.

113. Hernaiz, M. J.; Alcantara, A. R.; Garcia, J. I.; Sinisterra, J. V. Chem. Eur. J. 2010, 16, 94229437.

114. Quijano, G.; Couvert, A.; Amrane, A. Bioresour. Technol. 2010, 101, 8923-8930.

115. Hernandez-Fernandez, F. J.; Rios, A. P. D. L.; Lozano-Blanco, L. J.; Godinez, C. J. Chem. Technol. Biotechnol. 2010, 85, 1423-1435.

116. Earle, M. J.; Esperanca, J. M. S. S.; Gilea, M. A.; Lopes, J. N. C.; Rebelo, L. P. N.; Magee, J. W.; Seddon, K. R.; Widegren, J. A. Nature 2006, 439, 831-834.

117. Rogers, R. D.; Seddon, K. R. Science 2003, 302, 792-793.

118. Najdanovic-Visak, V.; Esperanca, J. M. S. S.; Rebelo, L. P. N.; da Ponte, M. N.; Guedes, H. J. R.; Seddon, K. R.; Szydlowski, J. Phys. Chem. Chem. Phys. 2002, 4, 1701-1703.

119. Komulski, M.; Gustafsson, J.; Rosenholm, J. B. Thermochim. Acta 2004, 412, 47-53.

120. Wasserscheid, P.; Welton, T. Ionic liquid in Synthesis; Wiley-VCH: Weinheim, 2003.

121. Anderson, J. L.; Ding, J.; Welton, T.; Armstrong, D. W. J. Am. Chem. Soc. 2002, 124, 1424714254.

122. Erbeldinger, M.; Mesiano, A. J.; Russell, A. J. Biotechnol. Progr. 2000, 16, 1129-1131.

123. Katsoura, M. H.; Polydera, A. C.; Katapodis, P.; Kolisis, F. N.; Stamatis, H. Process Biochem. 2007, 42, 1326-1334.

124. Lou, W. Y.; Zong, M. H.; Liu, Y. Y.; Wang, J. F. J. Biotechnol. 2006, 125, 64-74.

125. Vidya, P.; Chadha, A. J. Mol. Catal. B: Enzym. 2009, 57, 145-148.

126. Zou, B.; Hu, Y.; Yu, D.; Xia, J.; Tang, S.; Liu, W.; Huang, H. Biochem. Eng. J. 2010, 53, 150153.

127. Lee, S. H.; Ha, S. H.; Hiep, N. M.; Chang, W. J.; Koo, Y. M. J. Biotechnol. 2008, 133, 486489.

128. Toral, A. R.; los Roos, A. P.; Hernbndez, F. J.; Janssen, M. H. A.; Schoevaart, R.; van Rantwijk, F.; Sheldon, R. A. Enzyme Microb. Technol. 2007, 40, 1095-1099.

129. Adamczak, M.; Bornscheuer, U. T. Process Biochem. 2009, 44, 257-261.

130. Zhang, K. P.; Lai, J. Q.; Huang, Z. L.; Yang, Z. Bioresour. Technol. 2011, 102, 2767-2772.

131. Lee, S. H.; Doan, T. T. N.; Ha, S. H.; Chang, W. J.; Koo, Y. M. J. Mol. Catal. B: Enzym. 2007, 47, 129-134.

132. Wang, Y.; Mei, L. J. Biosci. Bioeng. 2007, 103, 345-349.

133. Yuan, J.; Fan, X.; Wang, Q.; Wang, P.; Cui, L. J. Biotechnol. 2008, 136, 499-502.

134. Zhao, H.; Jackson, L.; Song, Z.; Olubajo, O. Tetrahedron: Asymmetry 2006, 17, 1549-1553.

135. Nakashima, K.; Maruyama, T.; Kamiya, N.; Goto, M. Anal. Biochem. 2008, 374, 285-290.

136. Pollard, D. J.; Woodley, J. M. Trends Biotechnol. 2007, 25, 66-73.

137. Hussain, W.; Pollard, D. J.; Truppo, M.; Lye, G. J. J. Mol. Catal. B: Enzym. 2008, 55, 19-29.

138. Breutigam, S.; Dennewald, D.; Schurmann, M.; Lutje-Spelberg, J.; Pitner, W. R.; WeusterBotz, D. Enzym. Microb. Technol. 2009, 45, 310-316.

139. Christiansen, A.; Backensfeld, T.; Denner, K.; Weitschies, W. Eur. J. Pharm. Biopharm. In 
Press, Corrected Proof.

140. Cao, Q.; Quan, L.; He, C.; Li, N.; Li, K.; Liu, F. Talanta 2008, 77, 160-165.

141. Yan, R.; Zhao, F.; Li, J.; Xiao, F.; Fan, S.; Zeng, B. Electrochim. Acta 2007, 52, 7425-7431.

142. Ding, C.; Zhang, M.; Zhao, F.; Zhang, S. Anal. Biochem. 2008, 378, 32-37.

143. Sgalla, S.; Fabrizi, G.; Cacchi, S.; Macone, A.; Bonamore, A.; Boffi, A. J. Mol. Catal. B: Enzym. 2007, 44, 144-148.

144. Das, D.; Dasgupta, A.; Das, P. K. Tetrahedron Lett. 2007, 48, 5635-5639.

145. dos Santos Maguerroski, K.; Fernandes, S. C.; Franzoi, A. C.; Vieira, I. C. Enzyme Microb. Technol. 2009, 44, 400-405.

146. Brondani, D.; Dupont, J.; Spinelli, A.; Vieira, I. C. Sens. Actuators B: Chemical 2009, 138, 236-243.

147. Gaisberger, R. P.; Fechter, M. H.; Griengl, H. Tetrahedron: Asymmetry 2004, 15, 2959-2963.

148. Eckstein, M.; Villela, M.; Liese, A.; Kragl, U. Chem. Commun. 2004, 1084-1085.

149. Irimescu, R.; Kato, K. Tetrahedron Lett. 2004, 45, 523-525.

150. Irimescu, R.; Kato, K. J. Mol. Catal. B: Enzym. 2004, 30, 189-194.

151. Rasalkar, M. S.; Potdar, M. K.; Salunkhe, M. M. J. Mol. Catal. B: Enzym. 2004, 27, 267-270.

152. De Diego, T.; Lozano, P.; Abad, M. A.; Steffensky, K.; Vaultier, M.; Iborra, J. L. J. Biotechnol. 2009, 140, 234-241.

153. Bekhouche, M.; Doumoche, B.; Blum, L. J. J. Mol. Catal. B: Enzym. 2010, 65, 73-78.

154. Ulbert, O.; Frater, T.; Belafi-Bako, K.; Gubicza, L. J. Mol. Catal. B: Enzym. 2004, 31, 39-45.

155. Mohile, S. S.; Potdar, M. K.; Harjani, J. R.; Nara, S. J.; Salunkhe, M. M. J. Mol. Catal. B: Enzym. 2004, 30, 185-188.

156. Chiappe, C.; Leandri, E.; Lucchesi, S.; Pieraccini, D.; Hammock, B. D.; Morisseau, C. J. Mol. Catal. B: Enzym. 2004, 27, 243-248.

157. Okrasa, K.; Guibe-Jampel, E.; Therisod, M. Tetrahedron: Asymmetry 2003, 14, 2487-2490.

158. Persson, M.; Bornscheuer, U. T. J. Mol. Catal. B: Enzym. 2003, 22, 21-27.

159. Pfruender, H.; Amidjojo, M.; Kragl, U.; Weuster-Botz, D. Angew. Chem. Int. Ed. 2004, 43, 4529-4531.

160. Howarth, J.; James, P.; Dai, J. F. Tetrahedron Lett. 2001, 42, 7517-7519.

161. Matsuda, T.; Yamagishi, Y.; Koguchi, S.; Iwai, N.; Kitazume, T. Tetrahedron Lett. 2006, 47, 4619-4622.

162. Zhao, D.; Liao, Y.; Zhang, Z. Clean 2007, 35, 42-48.

163. Matzke, M.; Stolte, S.; Arning, U.; Uebers, U.; Filser, J. Green Chem. 2008, 10, 584-591.

164. Matzke, M.; Stolte, S.; Boschen, A.; Filser, J. Green Chem. 2008, 10, 784-792.

165. Hungerhoff, B.; Sonnenschein, H.; Theil, F. J. Org. Chem. 2002, 67, 1781-1785.

166. Swaleh, S. M.; Hungerhoff, B.; Sonnenschein, H.; Theil, F. Tetrahedron 2002, 58, 4085-4089.

167. Luo, Z. Y.; Swaleh, S. M.; Theil, F.; Curran, D. P. Org. Lett. 2002, 4, 2585-2587.

168. Brady, D.; Jordaan, J. Biotechnol. Lett. 2009, 31, 1639-1650.

169. Cao, L. Q.; van Langen, L.; Sheldon, R. A. Curr. Opin. Biotechnol. 2003, 14, 387-394.

170. Sheldon, R. A. Adv. Synth. Catal. 2007, 349, 1289-1307.

171. Khalaf, N.; Govardhan, C. P.; Lalonde, J. L.; Persichetti, R. A.; Wang, Y. F.; Margolin, A. L. 
J. Am. Chem. Soc.1996, 118, 5494-5495.

172. Reetz, M. T.; Zonta, A.; Simpelkamp, J. Biotechnol. Bioeng. 1996, 49, 527-534.

173. Lopez-Serrano, P.; Cao, L.; van Rantwijk, F.; Sheldon, R. A. Biotechnol. Lett. 2002, 24, 13791383.

174. Brady, D.; Jordaan, J.; Simpson, C.; Chetty, A.; Arumugam, C.; Moolman, F. S. BMC Biotechnol. 2008, 8, 8-19.

175. Mateo, C.; Palomo, J. M.; Fernandez-Lorente, G.; Guisan, J. M.; Fernandez-Lafuente, R. Enzyme Microb. Technol. 2007, 40, 1451-1463.

176. Palomo, J. M.; Fernbndez-Lorente, G.; Mateo, C.; Fuentes, M.; Fernandez-Lafuente, R.; Guisan, J. M. Tetrahedron: Asymmetry 2002, 13, 1337-1345.

177. Quiocho, F. A.; Richards, F. M. Biochemistry 1966, 5, 4062-4076.

178. Tischer, W.; Kasche, V. Trends Biotechnol. 1999, 17, 326-335.

179. Schoevaart, R.; Wolbers, M. W.; Golubovic, M.; Ottens, M.; Kieboom, A. P. G.; van Rantwijk, F.; van der Wielen, L. A. M.; Sheldon, R. A. Biotechnol. Bioeng. 2004, 87, 754762.

180. Sulek, F.; Fernández, D. P.; Knez, Z.; Habulin, M.; Sheldon, R. A. Proc. Biochem. 2011, 46, 765-769.

181. Wilson, L.; Fernández-Lorente, G.; Fernández -Lafuente, R.; Illanes, A.; Guisán, J. M.; Palomo, J. M. Enzyme.Microb.Technol. 2006, 39, 750-755.

182. Hara, P.; Hanefeld, U.; Kanerva, L. T. J. Mol. Catal. B: Enzym. 2008, 50, 80-86.

183. Forde, J.; Vakurov, A.; Gibson, T. D.; Millner, P.; Whelehan, M.; Marison, I. W.; Ó'Fágáin, C. J.Mol. Catal. B: Enzym. 2010, 66, 203-209.

184. Caballero, E.; Wilson, L.; Aroca, G. New Biotechnol. 2009, 25, S138.

185. Dijkstra, Z. J.; Merchant, R.; Keurentjes, J. T. F. J. Supercritic. Fluids 2007, 41, 102-108.

186. Kumar, S.; Mohan, U.; Kamble, A. L.; Pawar, S.; Banerjee, U. C. Bioresour. Technol. 2010, 101, 6856-6858.

187. Park, J. M.; Kim, M.; Park, J. Y.; Lee, D. H.; Lee, K. H.; Min, J.; Kim, Y. H. Proc. Biochem. 2010, 45, 259-263.

188. Gregory, R. J. H. Chem. Rev. 1999, 99, 3649-3682.

189. Effenberger, F. Angew. Chem. Int. Ed. Engl. 1994, 33, 1555-1564.

190. Schmidt, M.; Griengl, H. Biocatalysis - from Discovery to Application 1999, 200, 193-226.

191. Groger, H.; Capan, E.; Barthuber, A.; Vorlop, K. D. Org. Lett. 2001, 3, 1969-1972.

192. Cao, L. Q.; van Rantwijk, F.; Sheldon, R. A. Org. Lett. 2000, 2, 1361-1364.

193. Bruggink, A.; Roos, E. C.; De Vroom, E. Org. Proc. Res. Dev. 1998, 2, 128-133.

194. Pchelintsev, N. A.; Youshko, M. I.; Svedas, V. K. J. Mol. Catal. B: Enzym. 2009, 56, 202-207.

195. Illanes, A.; Wilson, L.; Altamirano, C.; Cabrera, Z.; Alvarez, L.; Aguirre, C. Enzyme Microb. Technol. 2007, 40, 195-203.

196. Crameri, A.; Raillard, S. A.; Bermudez, E.; Stemmer, W. P. C. Nature 1998, 391, 288-291.

197. Stemmer, W. P. C. Nature 1994, 370, 389-391.

198. Berchtold, M. W. Biological Chemistry Hoppe-Seyler 1990, 371, 758-759.

199. Bornscheuer, U. T.; Pohl, M. Curr. Opin. Chem. Biol. 2001, 5, 137-143. 
200. Cedrone, F.; Menez, A.; Quemeneur, E. Curr. Opin. Struct. Biol. 2000, 10, 405-410.

201. Jones, J. B.; DeSantis, G. Acc. Chem. Res. 1999, 32, 99-107.

202. Harris, J. L.; Craik, C. S. Curr. Opin. Chem. Biol. 1998, 2, 127-132.

203. Choi, E. J.; Mayo, S. L. Protein Eng. Des. Sel. 2006, 19, 285-289.

204. Suzuki, Y. Proc. Jpn. Acad. Ser. B 1999, 75, 133-137.

205. Clarke, J.; Fersht, A. R. Biochemistry 1993, 32, 4322-4329.

206. Flores, H.; Ellington, A. D. Protein Eng. Des. Sel. 2005, 18, 369-377.

207. Lehmann, M.; Wyss, M. Curr. Opin. Biotechnol. 2001, 12, 371-375.

208. Bonagura, C. A.; Sundaramoorthy, M.; Bhaskar, B.; Poulos, T. L. Biochemistry 1999, 38, 5538-5545.

209. Danielson, U. H.; Jiang, F. Y.; Hansson, L. O.; Mannervik, B. Biochemistry 1999, 38, $9254-$ 9263.

210. Wilcox, S. K.; Putnam, C. D.; Sastry, M.; Blankenship, J.; Chazin, W. J.; Mcree, D. E.; Goodin, D. B. Biochemistry 1998, 37, 16853-16862.

211. Gengenbach, A.; Syn, S.; Wang, X. T.; Lu, Y. Biochemistry 1999, 38, 11425-11432.

212. Mata, L.; Gripon, J. C.; Mistou, M. Y. Protein Eng. 1999, 12, 681-686.

213. Sinclair, R.; Reid, G. A.; Chapman, S. K. Biochemical J. 1998, 333, 117-120.

214. Cahoon, E. B.; Lindqvist, Y.; Schneider, G.; Shanklin, J. Proc. Natl. Acad. Sci. U.S.A. 1997, 94, 4872-4877.

215. Harris, J. L.; Peterson, E. P.; Hudig, D.; Thornberry, N. A.; Craik, C. S. J. Biol. Chem. 1998, 273, 27364-27373.

216. Mouratou, B.; Kasper, P.; Gehring, H.; Christen, P. J. Biol. Chem. 1999, 274, 1320-1325.

217. Kurth, T.; Grahn, S.; Thormann, M.; Ullmann, D.; Hofmann, H. J.; Jakubke, H. D.; Hedstrom, L. Biochemistry 1998, 37, 11434-11440.

218. Lee, S. C.; Kim, J. H.; Kim, H. S. Curr. Org. Chem. 2010, 14, 1894-1901.

219. Golynskiy, M. V.; Seelig, B. Trends Biotechnol. 2010, 28, 340-345.

220. Kohler, V.; Wilson, Y. M.; Lo, C.; Sardo, A.; Ward, T. R. Curr. Opin. Biotechnol. 2010, 21, 744-752.

221. Reetz, M. T. Angew. Chem. Int. Ed. 2011, 50, 138-174.

222. Lehman, N. Nat. Chem. Biol. 2011, 7, 252-253.

223. Horsman, G. P.; Liu, A. M. F.; Henke, E.; Bornscheuer, U. T.; Kazlauskas, R. J. Chem. Eur. J. 2003, 9, 1933-1939.

224. Carr, R.; Alexeeva, M.; Enright, A.; Eve, T. S. C.; Dawson, M. J.; Turner, N. J. Angew. Chem. Int. Ed. 2003, 42, 4807-4810.

225. Turner, N. J. Chim. Oggi-Chem. Today 2008, 26, 9-10.

226. Alexeeva, M.; Enright, A.; Dawson, M. J.; Mahmoudian, M.; Turner, N. J. Angew. Chem. Int. Ed. 2002, 41, 3177-3179.

227. DeSantis, G.; Wong, K.; Farwell, B.; Chatman, K.; Zhu, Z. L.; Tomlinson, G.; Huang, H. J.; Tan, X. Q.; Bibbs, L.; Chen, P.; Kretz, K.; Burk, M. J. J. Am. Chem. Soc. 2003, 125, 1147611477.

228. Funke, S. A.; Eipper, A.; Reetz, M. T.; Otte, N.; Thiel, W.; van Pouderoyen, G.; Dijkstra, B. 
W.; Jaeger, K. E.; Eggert, T. Biocatal. Biotransform. 2003, 21, 67-73.

229. Scrutton, N. S.; Berry, A.; Perham, R. N. Nature 1990, 343, 38-43.

230. Chen, R. D.; Greer, A.; Dean, A. M. Proc. Natl. Acad. Sci. U.S.A. 1996, 93, 12171-12176.

231. Declerck, N.; Machius, M.; Chambert, R.; Wiegand, G.; Huber, R.; Gaillardin, C. Protein Eng. 1997, 10, 541-549.

232. Chen, H. M.; Li, Y. X.; Panda, T.; Buehler, F.; Ford, C.; Reilly, P. J. Protein Eng. 1996, 9, 499-505.

233. Okada, Y.; Yoshigi, N.; Sahara, H.; Koshino, S. Biosci. , Biotechnol. , Biochem. 1995, 59, 1152-1153.

234. Henke, E.; Pleiss, E.; Bornscheuer, U. T. Angew. Chem. Int. Ed. 2002, 41, 3211-3216.

235. Chen-Goodspeed, M.; Sogorb, M. A.; Wu, F. Y.; Raushel, F. M. Biochemistry 2001, 40, 13321339.

236. Chen-Goodspeed, M.; Sogorb, M. A.; Wu, F. Y.; Hong, S. B.; Raushel, F. M. Biochemistry 2001, 40, 1325-1331.

237. Magnusson, A.; Hult, K.; Holmquist, M. J. Am. Chem. Soc. 2001, 123, 4354-4355.

238. Orrenius, C.; Haeffner, F.; Rotticci, D.; Ohrner, N.; Norin, T.; Hult, K. Biocatal. Biotransform. 1998, 16, 1-15.

239. DeSantis, G.; Liu, J. J.; Clark, D. P.; Heine, A.; Wilson, I. A.; Wong, C. H. Bioorg. Med. Chem. 2003, 11, 43-52.

240. Rotticci, D.; Rotticci-Mulder, J. C.; Denman, S.; Norin, T.; Hult, K. Chembiochem 2001, 2, 766-770.

241. Profir, V. M.; Matsuoka, M. Colloids Surf., A 2000, 164, 315-324.

242. Petrusevska-Seebach, K.; Seidel-Morgenstern, A.; Elsner, M. P. Cryst. Growth Des. 2011, 11, 2149-2163.

243. Lorenz, H.; Perlberg, A.; Sapoundjiev, D.; Elsner, M. P.; Seidel-Morgenstern, A. Chem. Eng. Process. 2006, 45, 863-873.

244. Yoshioka, R. Novel Optical Resolution Technologies 2007, 269, 83-132.

245. Francotte, E.; Linder, W. In Chirality in Drug Research; Wiley-VCH Verlag GmBH \& Co.: Weinheim, 2006; Vol. 33.

246. Brands, K. M. J.; Davies, A. J. Chem. Rev. 2006, 106, 2711-2733.

247. Ahuja, S. Chiral Separations; American Chemical Society: Washington, 1996.

248. Strauss, U. T.; Felfer, U.; Faber, K. Tetrahedron: Asymmetry 1999, 10, 107-117.

249. Stecher, H.; Faber, K. Synthesis-Stuttgart 1997, 1-16.

250. Bommarius, A. S.; Riebel, B. R. Biocatalysis: fundamentals and applications; Wiley-VCH Verlag GmBH \& KGaA: Weinheim, 2004.

251. Kumar, P.; Naidu, V.; Gupta, P. Tetrahedron 2007, 63, 2745-2785.

252. Ghanem, A. Tetrahedron 2007, 63, 1721-1754.

253. Kamal, A.; Azhar, M. A.; Krishnaji, T.; Malik, M. S.; Azeeza, S. Coord. Chem. Rev. 2008, 252, 569-592.

254. Aribi-Zouioueche, L.; Fiaud, J. C. Tetrahedron Lett. 2000, 41, 4085-4088.

255. Luckarift, H. R.; Dalton, H.; Sharma, N. D.; Boyd, D. R.; Holt, R. A. Appl. Microbiol. 
Biotechnol. 2004, 65, 678-685.

256. Rodriguez, C.; de Gonzalo, G.; Fraaije, M. W.; Gotor, V. Tetrahedron: Asymmetry 2007, 18, 1338-1344.

257. Maguire, A. R.; Kelleher, L. L. Tetrahedron Lett. 1997, 38, 7459-7462.

258. Adam, W.; Lukacs, Z.; Saha-Moller, C. R.; Schreier, P. J. Am. Chem. Soc. 2000, 122, 48874892.

259. Steinreiber, J.; Faber, K.; Griengl, H. Chem. Eur. J. 2008, 14, 8060-8072.

260. Pellissier, H. Tetrahedron 2003, 59, 8291-8327.

261. Ward, R. S. Tetrahedron: Asymmetry 1995, 6, 1475-1490.

262. Noyori, R.; Tokunaga, M.; Kitamura, M. Bull. Chem. Soc. Jpn. 1995, 68, 36-56.

263. Ebbers, E. J.; Ariaans, G. J. A.; Houbiers, J. P. M.; Bruggink, A.; Zwanenburg, B. Tetrahedron 1997, 53, 9417-9476.

264. Tan, D. S.; Gunter, M. M.; Drueckhammer, D. G. J. Am. Chem. Soc. 1995, 117, 9093-9094.

265. vandenHeuvel, M.; Cuiper, A. D.; vanderDeen, H.; Kellogg, R. M.; Feringa, B. L. Tetrahedron Lett. 1997, 38, 1655-1658.

266. vanderDeen, H.; Cuiper, A. D.; Hof, R. P.; vanOeveren, A.; Feringa, B. L.; Kellogg, R. M. J. Am. Chem. Soc. 1996, 118, 3801-3803.

267. Gastaldi, S.; Escoubet, S.; Vanthuyne, N.; Gil, G.; Bertrand, M. P. Org. Lett. 2007, 9, 837839.

268. Sakai, T.; Wang, K.; Ema, T. Tetrahedron 2008, 64, 2178-2183.

269. Vongvilai, P.; Larsson, R.; Ramstrom, O. Adv. Synth. Catal. 2008, 350, 448-452.

270. Vongvilai, P.; Angelin, M.; Larsson, R.; Ramstrom, O. Angew. Chem. Int. Ed. 2007, 46, 948950.

271. Maguire, A. R.; O'Riordan, N. Tetrahedron Lett. 1999, 40, 9285-9288.

272. Takaya, H.; Ohta, T. J. Synth. Org. Chem. Jpn. 1993, 51, 1013-1023.

273. Cook, G. R. Curr. Org. Chem. 2000, 4, 869-885.

274. Martin-Matute, B.; Edin, M.; Bogar, K.; Bäckvall, J. E. Abstr. Pap. - Am. Chem. Soc. 2004, 228, U36.

275. Pellissier, H. Tetrahedron 2011, 67, 3769-3802.

276. Lee, J. H.; Han, K.; Kim, M. J.; Park, J. Eur. J. Org. Chem. 2010, 999-1015.

277. Kim, Y.; Park, J.; Kim, M. J. Chemcatchem 2011, 3, 271-277.

278. Allen, J. V.; Williams, J. M. J. Tetrahedron Lett. 1996, 37, 1859-1862.

279. El Gihani, M. T.; Williams, J. M. J. Curr. Opin. Chem. Biol. 1999, 3, 11-15.

280. Kim, M. J.; Ahn, Y.; Park, J. Bull. Korean Chem. Soc. 2005, 26, 515-522.

281. Kim, M. J.; Ahn, Y.; Park, J. Curr. Opin. Biotechnol. 2002, 13, 578-587.

282. Choi, J. H.; Choi, Y. K.; Kim, Y. H.; Park, E. S.; Kim, E. J.; Kim, M. J.; Park, J. W. J. Org. Chem. 2004, 69, 1972-1977.

283. Fransson, A. B. L.; Xu, Y. M.; Leijondahl, K.; Bäckvall, J. E. J. Org. Chem. 2006, 71, 63096316.

284. Martin-Matute, B.; Aberg, J. B.; Edin, M.; Bäckvall, J. E. Chem. Eur. J. 2007, 13, 6063-6072.

285. Berkessel, A.; Sebastian-Ibarz, M. L.; Muller, T. N. Angew. Chem. Int. Ed. 2006, 45, 6567- 
6570.

286. Chabardes, P.; Kuntz, E.; Varagnat, J. Tetrahedron 1977, 33, 1775-1783.

287. Akai, S.; Tanimoto, K.; Kanao, Y.; Egi, M.; Yanamoto, T.; Kita, Y. Angew. Chem. Int. Ed. 2006, 45, 2592-2595.

288. Reetz, M. T.; Schimossek, K. Chimia 1996, 50, 668-671.

289. Parvulescu, A.; De Vros, D.; Jacobs, P. Chem. Commun. 2005, 5307-5309.

290. Parvulescu, A. N.; Jacobs, P. A.; De Vos, D. E. Adv. Synth.Catal. 2008, 350, 113-121.

291. Choi, Y. K.; Kim, M. J.; Ahn, Y.; Kim, M. J. Org. Lett. 2001, 3, 4099-4101.

292. Dumas, J. B. Ann. Chim. Phys. 1874, 5.

293. Crocq, V.; Masson, C.; Winter, J.; Richard, C.; Lemaitre, G.; Lenay, J.; Vivat, M.; Buendia, J.; Prat, D. Org. Process Res. Dev. 1997, 1, 2-13.

294. Servi, S. Synthesis 1990, 1, 1-25.

295. Faber, K. Biotransformation in Organic Chemistry, 3rd Completely Revised Edition; Springer: Heidelberg, Dordrecht, New York: 1997.

296. Halgaŝ, J. Biocatalysts in Organic Synthesis; Elsevier Amsterdam: 1991.

297. Khor, G. K.; Uzir, M. H. Yeast 2011, 28, 93-107.

298. Roberts, S. M. Preparative Biotransformations; Whole Cell and Isolated Enzymes in Organic Synthesis; John Wiley \& Sons Ltd: New York: 1997.

299. Stewart, J. D.; Rodriquez, S.; Kayser, M. M. Enzyme Technology for Pharmaceutical and Biotechnological Applications; Marcel Dekker: New York, 2001.

300. Richter, N.; Groger, H.; Hummel, W. Appl. Microbiol. Biotechnol. 2011, 89, 79-89.

301. Prelog, V. Pure Appl. Chem. 1964, 9, 119-130.

302. Stewart, J. D. In Biocatalysis in the pharmaceutical and biotechnological industries; CRC Press LLC: Boca Raton, Florida, 2007; pp 333-350.

303. Zhou, B. N.; Gopalan, A. S.; VanMiddlesworth, F.; Shieh, W. R.; Sih, C. J. J. Am. Chem. Soc. 1983, 105, 5925-5926.

304. Ehrler, J.; Giovannini, F.; Lamatsch, B.; Seebach, D. Chimia 1986, 40, 172-173.

305. Kelleher L.L. Ph. D. Thesis, National University of Ireland, Cork 1997.

306. O' Keeffe, E. Ph. D. Thesis, National University of Ireland, Cork 2002.

307. O' Riordan, N. Ph. D. Thesis, National University of Ireland, Cork 2001.

308. Nakamura, K.; Kawai, Y.; Oka, S.; Ohno, A. Tetrahedron Lett. 1989, 30, 2245-2246.

309. Maguire, A. R.; Collins, S. G.; Ford, A. Arkivoc 2003, 96-109.

310. Nakamura, K.; Kawai, Y.; Ohno, A. Tetrahedron Lett. 1991, 32, 2927-2928.

311. Lin, Y. H.; Hwang, S. C. J.; Shih, W. C.; Chen, K. C. J. Appl. Polymer Sci. 2006, 99, 738-743.

312. Crumbie, R. L.; Deol, B. S.; Nemorin, J. E.; Ridley, D. D. Aust. J. Chem. 1978, 31, 19651980.

313. Maguire, A. R.; Lowney, D. G. J. Chem. Soc. Perkin Trans. 1 1997, 235-238.

314. Maguire, A. R.; Kelleher, L. L.; Ferguson, G. J. Mol. Catal. B: Enzym. 1996, 2, 147-158.

315. Nakamura, K.; Ushio, K.; Oka, S.; Ohno, A.; Yasui, S. Tetrahedron Lett. 1984, 25, 39793982.

316. Arnone, A.; Bernardi, R.; Bravo, P.; Cardillo, R.; Ghiringhelli, D.; Cavicchio, G. J. Chem. 
Soc., Perkin Trans. 1 1991, 1887-1891.

317. Kozikowski, A. P.; Mugrage, B. B.; Li, C. S.; Felder, L. Tetrahedron Lett. 1986, 27, 48174820.

318. Tanikaga, R.; Hosoya, K.; Kaji, A. J. Chem. Soc., Perkin Trans. 1 1987, 1799-1803.

319. Svatôs, A.; Hunkova, Z.; Kren, V.; Hoskovec, M.; Saman, D.; Valterova, I.; Vrkoc, J.; Koutek, B. Tetrahedron: Asymmetry 1996, 7, 1285-1294.

320. Gotor, V.; Rebolledo, F.; Liz, R. Tetrahedron: Asymmetry 2001, 12, 513-515.

321. Fujisawa, T.; Itoh, T.; Nakai, M.; Sato, T. Tetrahedron Lett. 1996, 7, 771-774

322. Yamazaki, T.; Asai, M.; Ohnogi, T.; Lin, J.T.; Kitazume, T. J. Fluorine Chem. 1987, 35, 537555.

323. DiNunno,L.; Franchini,C.; Nacci,A.; Scilimati, A.; Sinicropi, M.S. Tetrahedron: Asymmetry, 1999, 10, 1913-1926.

324. http://www.genome.gov/10000510

325. Galibert, F.; Alexandraki, D.; Baur, A.; Boles, E.; Chalwatzis, N.; Chuat, J. C.; Coster, F.; Cziepluch, C.; DeHaan, M.; Domdey, H.; Durand, P.; Entian, K. D.; Gatius, M.; Goffeau, A.; Grivell, L. A.; Hennemann, A.; Herbert, C. J.; Heumann, K.; Hilger, F.; Hollenberg, C. P.; Huang, M. E.; Jacq, C.; Jauniaux, J. C.; Katsoulou, C.; Kirchrath, L.; Kleine, K.; Kordes, E.; Kotter, P.; Liebl, S.; Louis, E. J.; Manus, V.; Mewes, H. W.; Miosga, T.; Obermaier, B.; Perea, J.; Pohl, T.; Portetelle, D.; Pujol, A.; Purnelle, B.; Rad, M. R.; Rasmussen, S. W.; Rose, M.; Rossau, R.; SchaaffGerstenschlager, I.; Smits, P. H. M.; Scarcez, T.; Soriano, N.; Tovan, D.; Tzermia, M.; VanBroekhoven, A.; Vandenbol, M.; Wedler, H.; von Wettstein, D.; Wambutt, R.; Zagulski, M.; Zollner, A.; KarpfingerHartl, L. EMBO J. 1996, 15, 2031-2049.

326. Zagulski, M.; Herbert, C. J.; Rytka, J. Acta Biochim. Pol. 1998, 45, 627-643.

327. Oppermann, U. C. T.; Maser, E. Toxicology 2000, 144, 71-81.

328. Rodriguez, S.; Kayser, M. M.; Stewart, J. D. J. Am. Chem. Soc. 123, 1547-1555.

329. Shieh, W.; Gopalan, A. S.; Sih, C. J. J. Am. Chem. Soc. 1985, 107, 2993-2994.

330. Stewart, J. D. Curr.Opin. Biotechnol. 2000, 11, 363-368.

331. Kayser, M. M. J. Heterocycl. Chem. 1999, 36, 1533-1537.

332. Mihovilovic, M. D.; Chen, G.; Wang, S.; Kyte, B.; Rochon, F.; Kayser, M. M.; Stewart, J. D. J. Org. Chem. 2001, 66, 733-738.

333. Rodriguez, S.; Kayser, M. M.; Stewart, J. D. J. Am. Chem. Soc. 2001 123, 1547-1555.

334. Kawai, Y.; Hayashi, M.; Inaba, Y.; Saitou, K.; Ohno, A. Tetrahedron Lett. 1998, 39, 52255228.

335. Kruas, K.; Waldmann, H. Enzyme Catalysis in Organic Synthesis; John Wiley \& Sons: Weinheim, 1995; Vol. 1 \& 2.

336. Faber, K. Biotransformation in Organic Chemistry, 5 ed.; Springer-Verlag: Berlin, 2004.

337. Ikeda, M.; Kanao, Y.; Yamanaka, M.; Sakuraba, H.; Mizutani, Y.; Igarashi, Y.; Kihara, A. FEBS Lett. 2008, 582, 2435-2440.

338. Ema, T.; Moriya, H.; Kofukuda, T.; Ishida, T.; Maehara, K.; Utaka, M.; Sakai, T. J. Org. Chem. 2001, 66, 8682-8684.

339. Kaluzna, W. A.; Matsuda, T.; Sewell, A. K.; Stewart, J. D. J. Am. Chem. Soc. 2004, 126, 
12827-12832.

340. Huisman, G. W.; Liang, J.; Krebber, A. Curr. Opin. Chem. Biol. 2010, 14, 122-129.

341. Sanli, G.; Dudley, J. I.; Blaber, M. Cell Biochem. Biophys. 2003, 38, 79-101.

342. Caffrey, P. Chemistry \& Biology 2005, 12, 1060-1062.

343. Kosjek, B.; Nti-Gyabaah, J.; Telari, K.; Dunne, L.; Moore, J. C. Org. Process Res. Dev. 2008, 12, 584-588.

344. Pollard, D.; Truppo, M.; Pollard, J.; Chen, C. Y.; Moore, J. Tetrahedron: Asymmetry 2006, 17, 554-559.

345. Woodyer, R.; Zhao, H. M.; van der Donk, W. A. Febs J. 2005, 272, 3816-3827.

346. Relyea, H. A.; Vrtis, J. M.; Woodyer, R.; Rimkus, S. A.; van der Donk, W. A. Biochemistry 2005, 44, 6640-6649.

347. Gooding, O. W.; Voladri, R.; Bautista, A.; Hopkins, T.; Huisman, G.; Jenne, S.; Ma, S.; Mundorff, E. C.; Savile, M. M. Org. Process Res. Dev. 2010, 14, 119-126.

348. Nakamura, K.; Yamanaka, R.; Tohi, K.; Hamada, H. Tetrahedron Lett. 2000, 41, 6799-6802.

349. Nakamura, K.; Yamanaka, R. Chem. Commun. 2002, 1782-1783.

350. Parkinson, B. A.; Weaver, P. F. Nature 1984, 309, 148-149.

351. Nakamura, K.; Yamanaka, R. Tetrahedron: Asymmetry 2002, 13, 2529-2533.

352. Nakamura, K.; Yamanaka, R.; Matsuda, T.; Harada, T. Tetrahedron: Asymmetry 2003, 14, 2659-2681.

\section{Authors' Biographies}

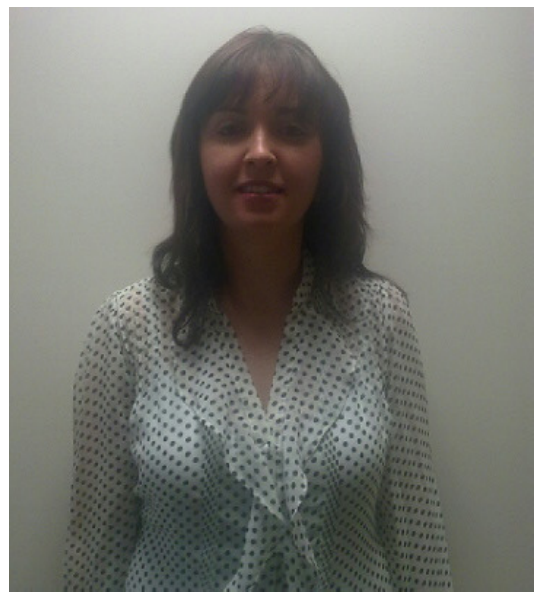

Sinéad Milner, University College Cork.

Sinéad Milner received her B.Sc in Chemistry of Pharmaceutical Compounds from University College Cork in 2005. She obtained her Ph.D under the supervision of Professor Anita Maguire. Her PhD research focused on biocatalysis employing whole cell and isolated enzymes in enantioselective synthesis, supported by an IRCSET-Pfizer scholarship for the duration of her PhD. She is currently a postdoctoral researcher in University College Cork. 


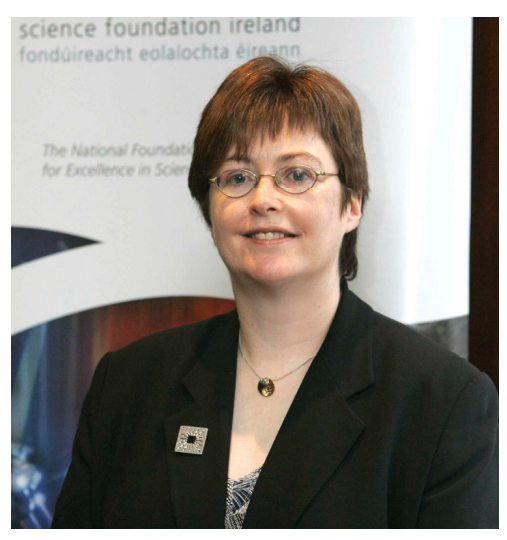

Prof. Anita Maguire, University College Cork.

Anita Maguire undertook undergraduate and postgraduate studies at University College Cork (B.Sc. 1985, Ph.D. 1989), focusing during her Ph.D on asymmetric catalysis in reactions of $\alpha$ diazoketones. Following postdoctoral research in the Facultés Universitaires, Namur, Belgium and subsequently at the University of Exeter, she returned to Cork in 1991. Her research interests include development of new synthetic methodology including organosulfur chemistry, asymmetric synthesis including biocatalysis, and the design and synthesis of bioactive compounds with pharmaceutical applications. 